\title{
On the Characteristics and Use of the 0ld in the Dramas of Euripides
}

Mifflin Wyatt Swartz, B.A., M.A. Professor of Lutin ant Greek, Millsnps College, Juckson, Miss.

A Dissertation Presented to the Faculty of the University

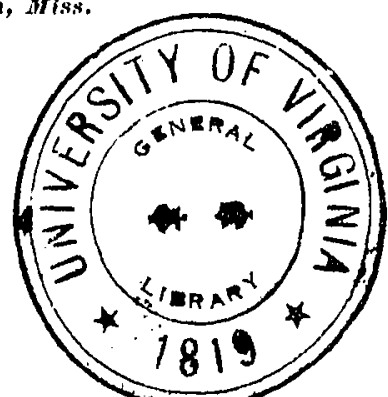
of Virginia June, 1910, as a Part of the Requirements for the Degree of Dootor of Philosophy

PUBLISHED FOA THE AUThOR PURtishing Hodsh of The M. E. ChuRCh, SodTh NASHVILLE, TENN. 1911 


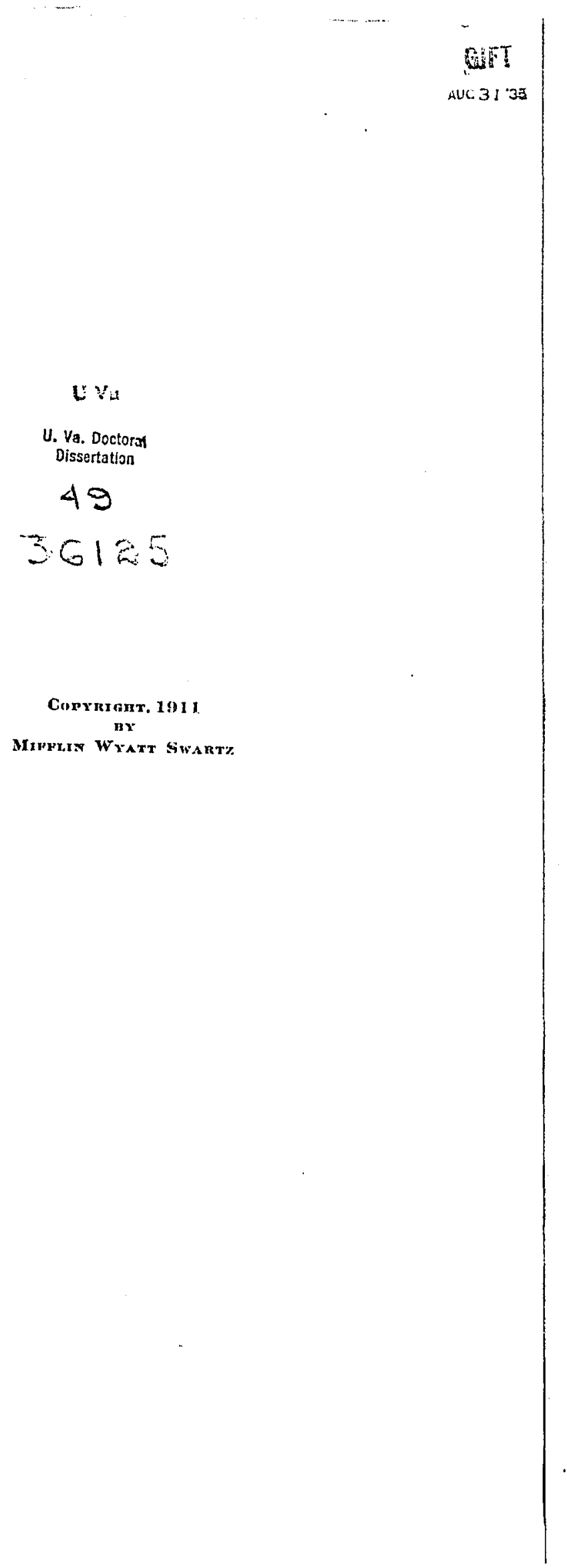




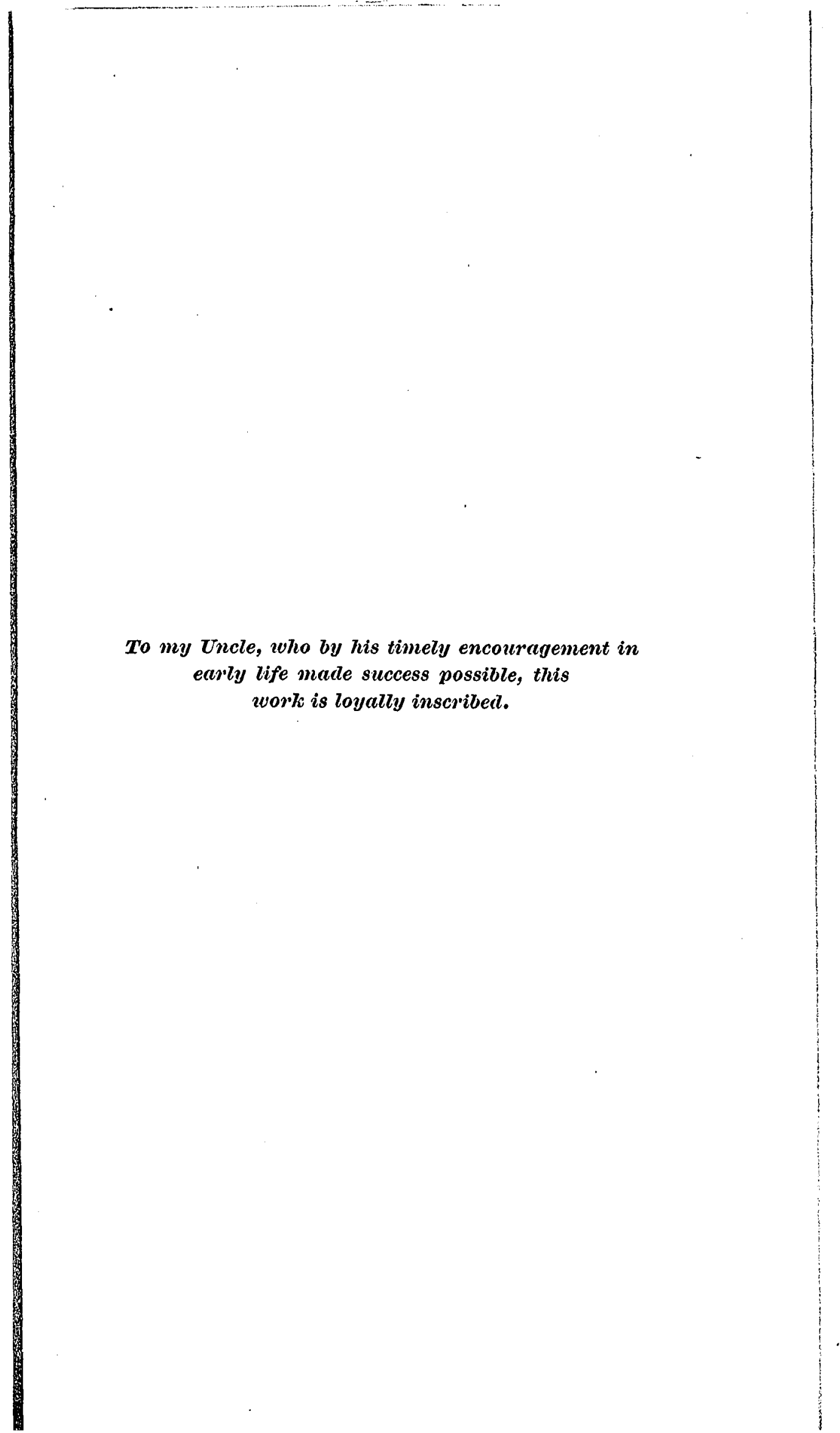





\section{OUTLINE OF DISSERTATION.}

Preface $\ldots \ldots \ldots \ldots \ldots \ldots \ldots \ldots \ldots \ldots \ldots \ldots \ldots \ldots \ldots \ldots \ldots$, vii-ix

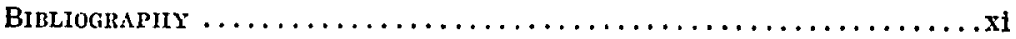

Statement of Proposirion $\ldots \ldots \ldots \ldots \ldots \ldots \ldots \ldots \ldots \ldots \ldots$ xiil-xiv

PERSONAL CHARACTERISTICS OF THE OLD.......... 1-79

1. Religious Sense .......................... $1-24$

(a) The old............................. 1-15

(b) The Young Contrasted $\ldots \ldots \ldots \ldots \ldots \ldots \ldots \ldots \ldots, 15-22$

(c) Additional Note ...................... 23

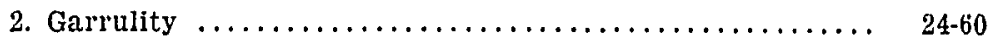

(a) Bodily infirmity combined with an ardent desile to be young and strong .................. 25-30

Ludicrous aspect of this trait . . . . . . . . . . $30-33$

Explanation of this trait ................ $34-39$

Belief that the old were a useless encumbrance, and that their work was done .............

The danger, to which the old were always liable, of being abused and maltreated ............

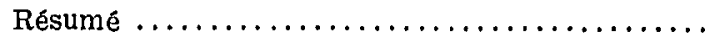

(b) Excitability of temper bordering sometimes upon extreme irascibility ......................

Repetition, tautology, grammatical irregularities. .

(c) A conviction that to give advice was the necessary

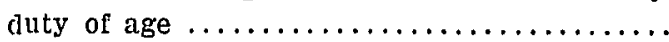

Explanation of and a consequent from $c \ldots . . .$.

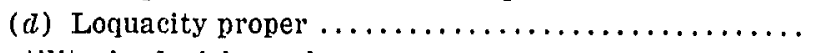

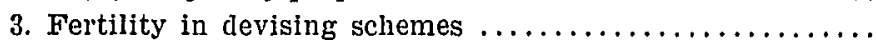

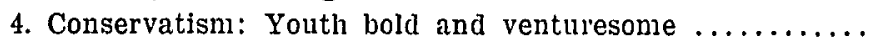

5. Milder traits $\ldots \ldots \ldots \ldots \ldots \ldots \ldots \ldots \ldots \ldots \ldots \ldots \ldots \ldots$

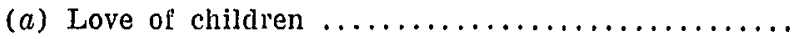

(b) Kindly sympathy for the afflicted $\ldots \ldots \ldots \ldots \ldots$

(c) Love of peace $\ldots \ldots \ldots \ldots \ldots \ldots \ldots \ldots \ldots \ldots \ldots$

(d) Attachment to friends $\ldots \ldots \ldots \ldots \ldots \ldots \ldots \ldots$

(e) Keen sense of justice $\ldots \ldots \ldots \ldots \ldots \ldots \ldots \ldots \ldots$

(f) Good-natured paternal condescension to younger peo-

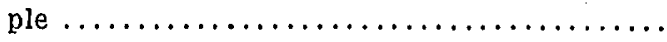

(g) Result of these milder traits $\ldots \ldots \ldots \ldots \ldots \ldots \ldots \ldots$

DRAMATIC CHARACTERISTICS OF THE OLD ......... 83-111

1. To engender a feeling of deep pity ................ 85

2. To enlist the sympathies of the audience $\ldots \ldots \ldots \ldots \ldots .93$

EXCURSUS ON THE TIME IMPLIED IN TO FHPA...$\ldots \ldots$. 111-115 


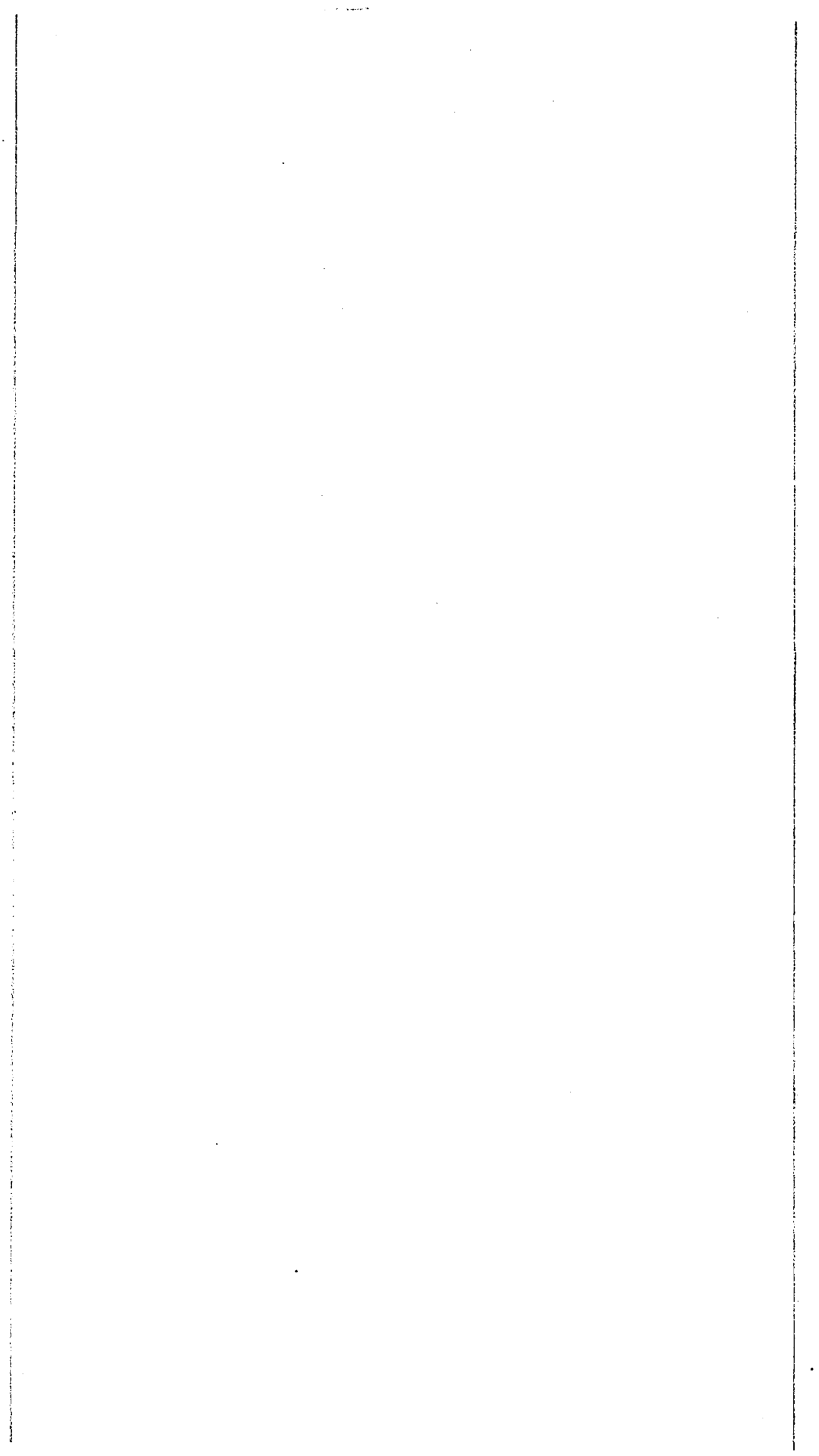




\section{PREFACE.}

Eurrprbes has always been the subject of much scrutinizing study. Even in his own day (we know on the authority of the great Comedian himself) the audiences which sat thru the day listening to the master's work went away to apply the "rule and square" to his words, phrases, and turns of thot. ${ }^{1}$ From that time on thru schlegel to the present day Euripides has been "ruled and squared," interpreted and misinterpreted-if I may say it-until, could he himself speak to us, he would, no doubt, adapting with fine irony the words of

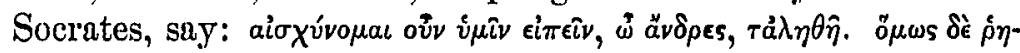

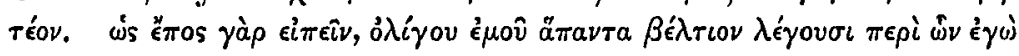
$\pi \epsilon \pi \circ i \eta \kappa .^{2}$

Recently a fresh impetus has been given to this" "ruling and squaring" of Euripides by the rise of an English school of nove ${ }^{3}$ criticism headed by Dr. Verrall in his epoch-making works: "Euripides: The Rationalist" and "Four Plays of Euripides." Any fresh study, therefore, of Euripides which might add a little-even tho it be but very little-to our knowl. edge of the "most tragic of the poets" would not be illtimed. Consequently I was led to undertake the following discussion "On the Characteristics and Use of the Old in the Dramas of Euripides" in the hope that I might enlarge, to some extent at least, the conception which the world of Greek scholarship has of the accuracy and clearness with which Euripides perceived the inner workings of that most subtle of all subtle things-human nature, and of the skillful use he made of that perception in the development of his plays."

1Alistoph. Ran. 956-9. 2Plato, Apol. VII. 22b.

sDr. Verrall thinks his method as old as Lucian. See Eurip.: The Rationalist, p. 139, 167, et al., especially p. $197 \mathrm{ff}$.

4Paul Rumpe: Euripides und der seelische Kampf in seinen Stuecken, p: 11, says of Euripides along this line: "Er muss Die Menchen studiert haben mit einem Fleiss und einem Interesse, das nur durch sein Genie uebertroffen sein mag. . . . Er ist gleichsam hinab gestiegen in das Innere des Menschens und hat dort fuer die Tragoedie eine neue Welt entdeckt: meisterhaft hat er die geheimen Falten des menschlichen Herzens herausgekehrt und uns den ersten Keim des Wollens oder Begehrens-gezeigt und ebenso wieder kund gethan, 
Of course it is not claimed that Euripides alone of the Ancients perceived the attributes of old age herein catalogied. In fact, there are traces in Homer, Aristophanes, Plato, Xenophon, and others, of some at any rate (it not of all) of the traits of the old, which the following pages discuss. It might not be too much to say that in general the Greeks of Euripides' day were well aware of the most pronounced characteristics of old age. ${ }^{1}$ Were this not so, the point and pith of Euripides' use of them would in part have been lost and their appearance upon the stage would have been flat and insipid. Euripides, however, with that keen perception of his saw that the attributes of the old-pronomnced and striking as they werewere especially adapted to the needs of his stage. And he sems to have used them almost from the very first in working out his dramatic purposes.

In discussing the religious trait of the old I have gone more lengthily into the opposite trat of the young than $\mathrm{I}$ have in the case of the other personal characteristics. It seemed to me that the point possibly demanded a somewhat more contrasted study.

I have based my discussion upon the recent Oxford text of Gilbert Murray, so far as lis two published volumes cover the plays. Elsewhere I have chiefly used (for the text) Paley's edition. For the tragments 1 have nsed Nauck, Vol. III., and Wagner's Euripides Perditarmm Fabularum Fragmenta. The numbering, however, is Naucl's. In the outline of the lost dramas I have followed Hartung in his Euripides Restitutus.

No acklowledgment of indebtedness has knowingly been

wie die That auf das Gemuet Einfluss gewinnt und den Menschen nach diesel oder jener Richtung treibt. Darin aber besteht las wahrhaft Dramatische."

"For example, the tendency of the old towards admonition and religion had shaped itself into a proverb,

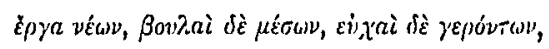

towards weakness and imbecility into:

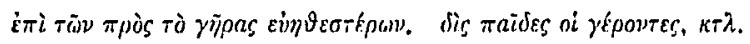

See Koch: Quaestionum de proverbiis apud Aeschylum Sophoclem Euripidem caput alterum, pp. 6, 7. 
omitted. Such acknowledgment will be found in the footnotes and in other proper places. To Prof. M. W. Humphreys, Professor of Greek in the University of Virginia, I desire here, however, to say that I am especially and profoundly indebted for his great kindness and inspiration to me thruout my entive work.

M. W. SWartz.

Jaclison, Miss., June, 1910. 


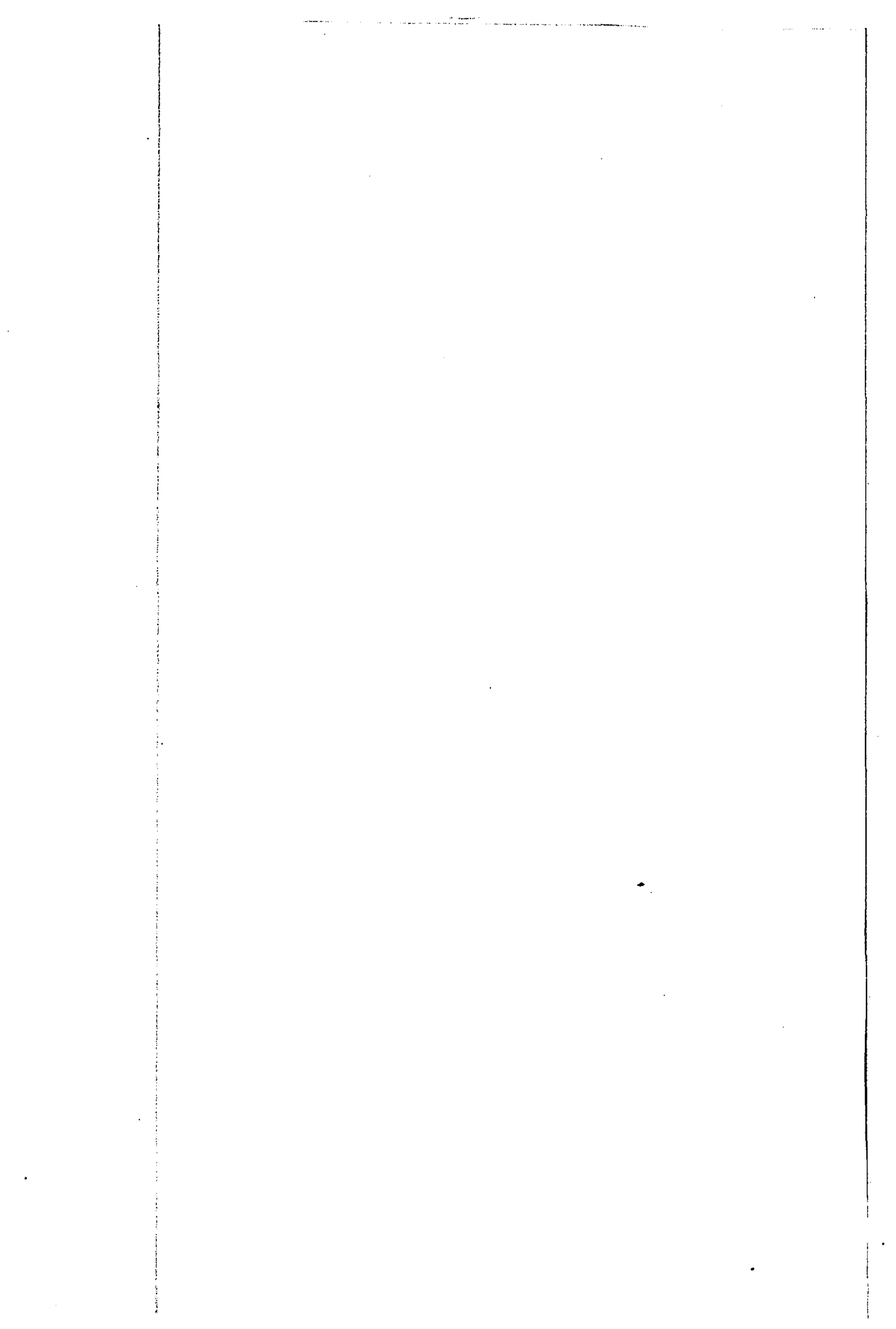




\section{A PARTTAI BIBLIOGRAPHY.}

Many pamphlets and brochures to which I am indebted are referred to in the notes. They need no cataloguing here.

The Moral Standpoint of Euripides, W. H. S. Jones; Euripides and the Spirit of his Dramas, Decharme; The Riddle of the Bacchae, Gilbert Norwood; De Puerorum in Re Scaenica Graecorum Partibus, Vol. XIII., Par. IV., Dissertationes Philologicae Halenses, Conradus Haym; Iphigenia at Aulis, England; Ion, Bayfield; Euripides, der Dichter der Griechischen Aufklaerung, Nestle; Euripides, Paley; Euripides (Oxford Text), Murray; La Cité Antique, Fustel de Coulanges; Alcestis, Jerram; Euripides: The Rationalist, Verrall; Four Plays of Euripides, Verrall; Aristotle: Theory of Poetry and Fine Arts, S. H. Butcher; Euripides Tragoediae, Hermann; Euripides Phoenissen, Muff; Euripides Tragoediae, Nauck (Vol. III.); Euripidis Perditarum Fabularum Fragmenta, Wagner; Études sur les Tragiques Grec., M. Patin, Vols. II., III.; Herakles, WHlamowitz-Moellendorff; De la Condition de la Femme, Lallier; Sept Tragédies d'Euripide, Weil; Philonis Alexandrini Opera, Vol. I., Edd. Cohn-Wendland; Lehrbuch der Griechischen Antiquitaeten, Vol. IV., Karl F. Hermann; Euripides Restitutus, I. A. Hartung.

(xi) 


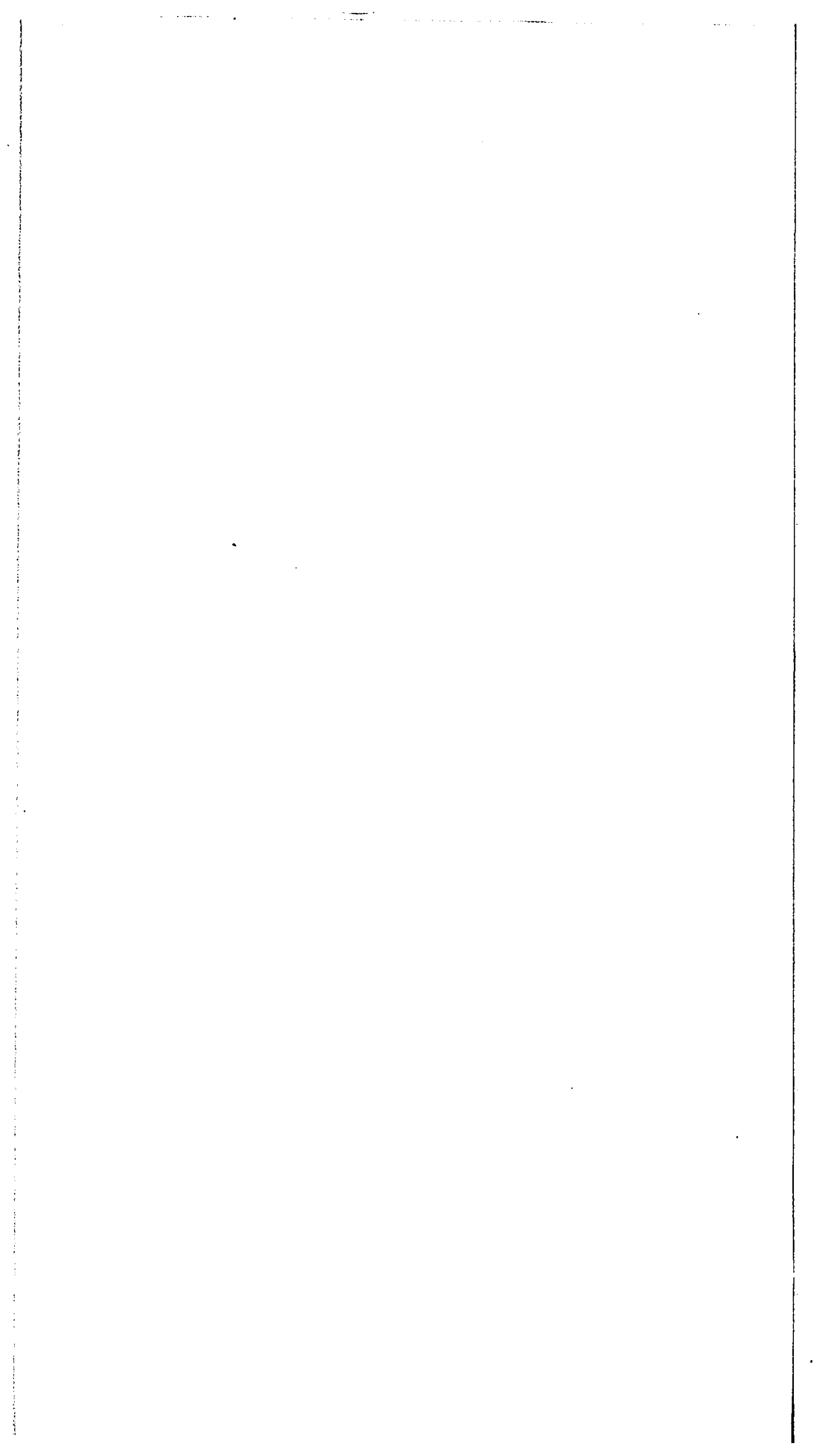




\section{STATEMENT OF PROPOSITION.}

Eres a hasty reading of Euripides impresses one with the frequency with which old men and old women characters are introduced into his dramas. In all his extant works, except the Rhesus and the Taurian Iphigenia (and of these two, the Euripidean authorship of the Rhesus is a matter of dispute), old men and old women are introduced. They are not infrequeutly the leading diamatis persone; ${ }^{1}$ and even when they do not themselves lave the leading roles to play, their parts are sometimes so prominent as to make them conspicuous thruout the play even when they themselves are not speaking, or even on the stage."

When, however, one begins with minute study to scrutinize the plays individnally and then to consider them in relation to one another the conclusion is forced upon one that the old men and old women in the dramas of Euripides are no chance creations, but that they have marked and permanent characteristics and that the whimsical humors which they evince and which amuse us at this moment are not in reality inharmonious nor incongruous with those lovable and noble traits of character which stir us and move us to tears the next. We see, no matter under what circumstances or environment the old are introduced, the sime general and well-defined traits of character-marks, so to speak-stamping the old and branding the character a $\gamma^{\prime} \cos \omega \nu$ or a $\gamma$ pavis.

Nor is this all. The old have not only marked personal characteristics, but they have marked dramatic characteristics as well. By "dramatic characteristics" we mean this: Whenever Earripides wants to produce certain effects, he uses old people; and the more desirous he is to produce these elfects, the more certain he is to give old men or old women important

Iolaus in the Heraclicla; Silenus in the Cyclops; Hecuba in the Hecuba; Hecuba in the Troades; Kreon and Ioltasta in the Phoenissae; Adrastus and Aethra in the Supplices, etc.

2 'The nurse in the Hippolytus leaves the stage at line 708. She does not again appear, tho the effect of her presence is felt and she herself is a potent factol even to the end of the play. In the Ion the $\pi \rho \varepsilon \sigma \beta v^{\prime} y / g$ is an active character even after he leaves the stage at line 1047, etc. 
roles in the play, either making them the leading personages themselres or assigning them a strong secondary part.

A study of the old in Euripides, therefore, naturally divides itself into two chief lines of investigation:

(a) An analysis of their personal characteristics.

(b) A deduction therefrom as to their dramatic characteristics-i. e., the function they discharge in the movement of the drama. 
PART ONE.

PERSONAL CHARACTERIS'TICS OF THE OLD IN EURIPIDES.

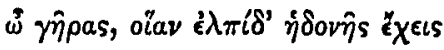

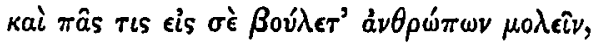

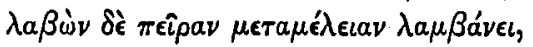

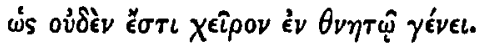

(Inc. Frag., 1065.)

$(\mathbf{x} \mathrm{V})$ 
The Dramas of Euripides.

he does not as a rule put into the mouths of his old characters atheistical words. He seems to feel that it ill became those whose day of fate would soon be upon them to hurl defiance into the face of the gods and to cast religion to the winds. ${ }^{1}$ Consequently the old evince as a rule a lively trust in the gods and express dependence upon them. Adrastus in the Suppiices, himself a "graybeard," represents the attitude of the old toward the gods when he says:"

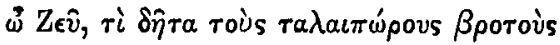

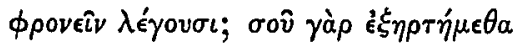

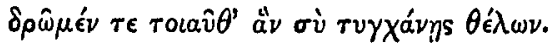

Hecuba, when entreating Agamemnon to give her aid in avenging Polydorus' death upon Polymuestor, declares:*

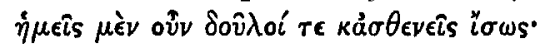

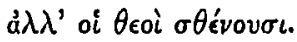

Here we have an orthodox utterance. The three following lines do not affect the case at all, for whether vómos means "established custom" or "rational conviction" the fact remains that Hecuba here alfirms her firm belief in the gods."

In the Bacche there are two very old men, Tiresias and Cadmus, the former blind from age, and the latter so old that he las resigned the government to his grandson, Pentheus. ${ }^{7}$ The religious sense is deeply developed in these two old men. Even before they appear, within the first ten lines of the

orthodox utterances were a concession to pious prejudices. "The creed of Euripides," he says, p. 79, "was that of nascent philosophy, science, and rationalism." And again, "It was the purpose and effect of his plays to destroy the old religious beliefs. . . . . There is scarcely on $\theta$ of his extant plays which would not prove him a determined enemy of the popular religion," pp. 80,81 .

1Care must be had, or we shall make too broad an application of Dr. Spengler's statement in his Theologumena Iuripidis, p. 2, in which he says: "Euripides per omnes tragoedias dubitationes et religionis antiquae institutorumque receptorum vituperationes, quamvis hoc illove loco a moribus auctorum abhorrerent, libenter consultoque dispersit." He did not do this by means of the old.

aSupplices, 166. iSupplices, 734-6. HHecuba, 798-801.

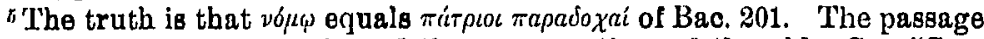
thus becomes an expression of the conservatism of the old. See "Conservatism," p. 67 , note 1 .

०Bacchæ, $210 . \quad$ iBacchæ, 213. 
drama, in the prologue of Dionysus, Cadmus is referred to in complimentary terms ${ }^{1}$ by the god for his piety and reverence in having his daughter's tomb made a sanctuary after she had been killed by Zeus' thunderbolt."

The scene between Tiresias and Cadmus" is especially interesting. They have come together for the purpose of combating the atheistical tendency of the people, and have determined to go the lengths even of dancing and bringing a reproach upon their old age for unusual conduct in order to accomplish their end. As they advance to the rites of worship old Cadmus, filled with deep piety, says:"

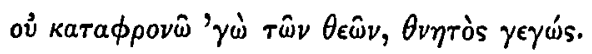

To which Tiresias in reply expresses $h$ is firm belief also in the gods and his refusal to sympathize with any rationalistic philosophy. No plausible reasoning shall be permitted to shake his belief in his ancestral religion. God must be honored in all respects by young and old. ${ }^{\circ}$

Further on, after the grossest insults had been heaped upon him by the godless Pentheus, in a calm and dignified speech ${ }^{7}$ he refutes the "erroneous and irreligions"s opinions of Pentheus. This speech breathes a deep spirit of trust and belief in the gods. In it old 'Tiresias goes to the length (as the old did not always do $)^{0}$ of accepting the tales of mythology literally; ${ }^{10}$ and in his pious zeal for divine aflairs defends the gods against the charges of impious men. The appeal which he and Cadmus make to Pentheus to heed their warning words and to desist from this mad and dangerous course is pathetic. It

1 Bacchæ, $9 \mathrm{ft}$.

It was believed by the pious that the body of a person liilled by lightning was especially sacled. Cr. Supplices 935 where Capaneus is to be burled apart from the others as a sacred corpse.

"Bacchæ, beginning with line 170. 4Bacchæ, 204-0. "Bacchæ, 199. -Bacchæ, 200, 201-3, 208. TBacchæ, 266-325. sBacchæ, Paley.

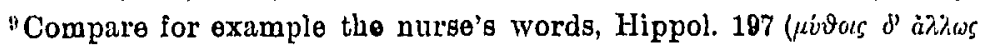
申ep $\langle\mu \varepsilon \sigma \vartheta a$ ), where she declares (in the words of Decharme, p. 91) that "Corberus, Charon's boat, Cocytus, and Acheron are empty fables." It must not to be forgotten, however, that the nurse is at this time almost "worried to deatll" by Phædra's petulancy. Later, $440 \mathrm{ff}$., the nur'se is as staunch an advocate of the "myths" as one would care to find. $10287 \mathrm{ff} ., 314 \mathrm{ff} .$, et $a l$. 
breathes a deep reverence and awe of the gods. It comes from their souls. 'Tiresias' appeal is : ${ }^{1}$

$$
\begin{aligned}
& \dot{a} \lambda \lambda^{\prime} \dot{\epsilon} \mu 0_{0}, \prod_{\epsilon} \epsilon \theta \varepsilon \hat{v}, \pi \iota \theta_{0} \hat{v} \text {. }
\end{aligned}
$$

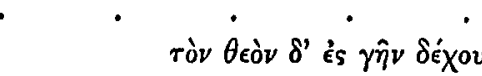

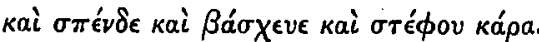

Cadmus' appeal is similar to it:" "Be wise, O Pentheus," he says, "consider the strength of" the gods; do not entice them to punish thee for thy irreverence."

And when at last Pentheus proves himself impervious to their entreaties to give up this dangerous attitude of impiety and insolence towards the gods, their deep religious sense immediately suggests to them the efficacy of prayer. They have recourse to that great boon of the old, prayer." Tho insulted and maltreated, they offer up a prayer for the wayward man. Nothing could show a deeper feeling of pure religion than the following: :

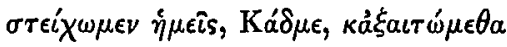

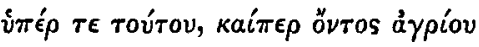

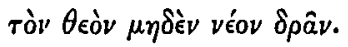

Towards the end of the phay," as Cadmus stands orercome with grief at the death of Pentheus, and at his own defenseless state, now that the protector of his old age has been taken from him, he does not utter one syllable against the god. On the contrary, the doom of Pentheus seems to have deepened his reverence. "If there is still any one," lie says, "who despises and doubts the god, let him look upon the fate of Pentheus and believe." And no sooner does Agave (note the instability of the religious feeling of the former impetuous bacchanal-Agave is young) begin to complain of the distress and terrible outrage ${ }^{7}$ which the god has brought on their home than Cadmus defends him. "Yes," says he, "but you know his provocation was very great, being dishonored, as he was, in his native Thebes."

In the Hecuba we meet an old decrepit figure in the person

1309. $2330 \mathrm{ff}$. 'See Preface, page vili., note 1 (Gnome on old age). Bac. 360 ff. "Bac. 1303 ff. "Bac. 1326-7. iBac. 1373-5-6. 8Bac. 1376-7. 
of Hecuba herself, hobbling over the stage supported now by her attendants ${ }^{1}$ and now by a crooked staff in her hands. ${ }^{2}$ Her advanced age is well attested by her snowy locks. ${ }^{8}$ She is hardly on the stage before, overcome by her distressing situation, she pours out her soul in prayer. Her faith seems to take in the entire pantheon. ${ }^{4}$ On the occasion of each new excitement her soul seems naturally to fly to prayer. And the chorus of slave women who come in to advise her of the decree of the Greelss that Polyxena must be sacrificed to the shade of Achilles, humoring this so evident tendency of hers, urge her to prayer as her only hope. ${ }^{\circ}$

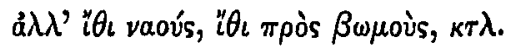

This strain of religious exaltation is maintained thruout. It culminates, perhaps, in her appeal to Agamemnon to help her avenge herself upon Polymnestor. In that speech she aver's: "Tho we are but slaves and weak, the eternal gods are strong. For we believe in them and live deciding right and wrong."

In the Alcestis the chorus of old men are continuously breathing ${ }^{s}$ a devout and worshipful spirit."

In their distress at Alcestis' approaching death the old men turn instinctively to the god as their only help. ${ }^{10}$

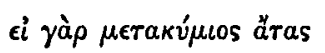

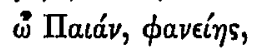

and they express the confident belief that if only ALsculapius, Phobus' son, the Great Physician, were there Alcestis, even if dead, would be raised to life. ${ }^{11}$ Again, when these same old men hear that Alcestis is still breathing, they hie themselves to prayer. Tho aftairs are in a direful shape, "Let us

1Hec. 62-3. 2Hec. 65. 3Hec. 500. 4Hec. 67-8, 77. sHec. 144. oHec. 798-800. Seo p. 2 , note 4.

iI have thruout the paper treated the chorus of the Alcestis as of old men, tho aware of the question which has been raised here by Julius Ritter in his Doctor's dissertation: De Euripidis Alcestide: Jena, 1875.

sDr. Verrall speaks of them as the "slaves of oracular dictum." Eurip. the Rationalist, p. 95.

oAlc. $962,966,978,979$. 10Alc. 91-2.

11Alc. 122-6. 
pray," they say, "for" God can help if he will. His power is supreme."

$$
\begin{aligned}
& \dot{a}^{3} \lambda \lambda^{\prime}{ }^{\circ} \mu \omega s
\end{aligned}
$$

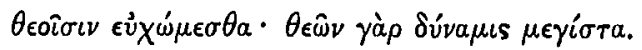

And the prayer they make is pathetic and eamest, breathing a spirit of devotion and trust based upon past experience. ${ }^{2}$

So it is elsewhere thruout the play. These old men are always showing their religions feeling by word or act. Their piety is unmistakable. Even old Pheres, self-centered and exhibiting some very unlovable traits of character, is religious. Tho on the stage but a short while, and with his hands full, it would seem, with the quarrel with his son, yet even under these circumstances he evinces a religious characteristic. He prays a short but fervent prayer for the peace of Alcestis' soul. ${ }^{3}$

In the Heraclidx the old characters are Iolaus, the chorus, and Alcmene. In the similar play, the Supplices, the old are Adrastus, the chorus, Ethra, and Iphis. In all of these, as in the characters we have already discussed, there is displayed the same marked religious trait.

The opening scene in the Hernclida presents to us Iolaus in deep distress and danger, clinging to the altar of the god, trusting him and availing limself of the right of a $\sigma v \lambda_{i a}$. His attitude toward things religious ean easily be seen by the fact that he is an outcast from his own land, suffering insults of all kinds, simply because he has been true to the things he considers sacred." His character thruont the play is well attested by his remark to Copreus, who is threatening to tear him by force from the altar. "The altall of the god is sufficient for me," he says. And further on in the play he does not want to leave the altar," even tho assured that Demophron will champion his cause. ${ }^{7} \mathrm{By}$ some chance the work of mo. bilization $^{8}$ of the Athenian army may be delayed. He feels that he is better where he is in the protection of the god till there is no longer any danger:" He stays, therefore, at the altar to pray for the success of the Athenian cause. ${ }^{20}$

The initial scene of the Supplices displays Ethra, the aged

1Alc. 219. 2Alc. 220 ff. 3Alc. 625. tHeracl. 6, 18. "Heracl. 61. 0Heracl. 344. iHeracl. 340-3. \$Heracl. 335. "Heracl. 346-7. 10Heracl. 334. 
mother of Theseus, at the altar of the god at Eleusis, whither, impelled by her piety, she had come to make a solemn sacrifice for the yearly crops, ${ }^{1}$ obviously feeling so firm a conviction in their beneficent presence as to justify her belief in their ability to bless the yearly yield. And when she takes upon herself the task of persuading her stubborn son to succor the distressed suppliants, her first argument is a religious one-

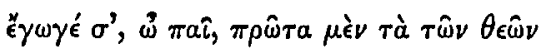

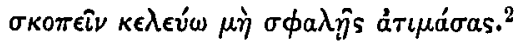

And she does this not because she thinks religion will influence the erratic Theseus (he was religious only for spectacular purposes and on occasion), but because the religious phase of the question was dearest to her heart.

In both dramas, the Heraclidæe and supplices, an exactly similar scene occurs, a prelude where the chorus of old men and women in a flurry of excitement speak to the audience their hopes and fears. The fundamental conception of both choruses is trust in God. In the Heraclide, the chorus says:

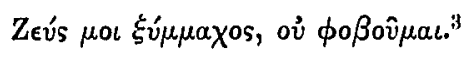

That in the Supplices sings:

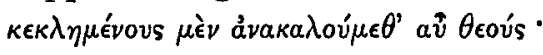

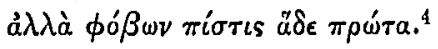

And their first thot after they hear the successful issue of the battle is their trust in God." Just as the first act of Iolaus after the battle in the Heraclidie is to set up a trophy to Zeus." And it is this Iolaus who, amid the excitement attendant upon military preparation, finds his chief comfort in the thot that Pallas is on their side and that she will not sulfer herself to be conquered.

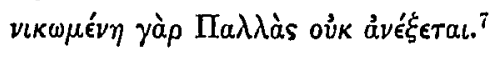

It is Iolaus also who, as the victorious army of Eurystheus is approaching and all fear the outcome of the war, finds consolation in the thot that it is just such a puffed-up mark as Eurystheus is that Zeus delights to hit.

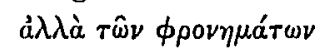

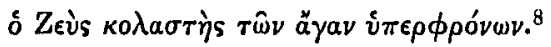

1Suppl. 28. 2Suppl. 301-2. 3Heracl. 766. +Suppl. 626; cf. also 615617. 5Suppl. 731-3. "Heracl. 936. iHeracl. 352. 8Heracl. 387, 388. 
The Dramas of Buripides.

Nothing could perhaps better show the absolute reverence and trust in the gods which the old display than Iolaus' response to Demophron when the latter, after having espoused the cause of Iolaus, announces to him that he must abandon it. All the oracles had declared that a high-born maid must be sacrificed ${ }^{1}$ before success would crown the Athenian arms. Demophron will not sacrifice his own daughter, nor will he force any of his subjects to sacrifice theirs. Hence be must abandon Iolaus to his fate. In this distressing turn of affairs Iolaus' faith does not waver. His first words after his first bitter disappointment strike the keynote of his thot. "If it is God's will that I suffer thus," etc., he says:

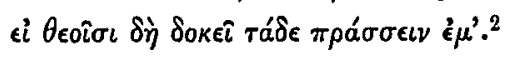

And later, when bidding Macaria good-by, and when, pressed down by his grief, he was inclined to murmur against the fate which made such a demand upon him, we find only the guarded statement: "I hesitate to speak ill of

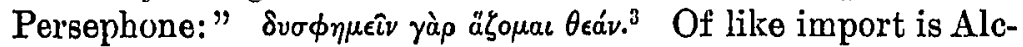

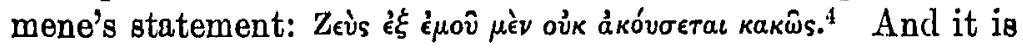
with evident delight that she seizes the first opportunity ${ }^{5}$ which presents itself to glorify his name and to repudiate any criticism which might have been implied in the line (718) just quoted. Her first feeling too is a pious one when she sees her great enemy Eurystheus being led captive before her.

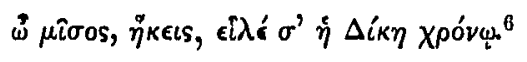

In like manner also in the Supplices it is Adrastus, the graybeard, ${ }^{7}$ who is made to reflect on the issue of the war. 'These reflections are "conceived in a spirit finely opposed to human pride." "Why do men say that wretched mortals are wise?" he asks. "We are (utterly) dependent upon God and do only those things which he permits." And this spirit of meditative philosophy characterizes his actions. Tho he cannot understand the hard purpose of Apollo ${ }^{10}$ in ordering him to marry his daughters to foreigners, yet just so soon as the first opportunity presents itself he implicitly obeys, tho the issue is

\footnotetext{
1Heracl. 407. 2Heracl. 437. 3Heracl. 600. 4Heracl. 718.

5Heracl. 869. 0Heracl. 941. 7Suppl. 166. sPaley, Suppl. note to line 734. OSuppl. 734-6. See p. 2, note 3. 10Suppl. 138.
} 
war and humiliation. This same reverence and awe of the gods he shows in the Phœnician Maidens. In the battle at the gates, when Capaneus is killed and Adrastus recognizes the hand of God in his death, he immediately withdraws the Argive army from the contest. ${ }^{1}$

In the Cyclops the religious instinct of the old is made to serve a very humorous turn. Old silenus has got himself into "quite a fix" disposing of his master"s meat and cheese. The chance to get a taste once again of the much-longed-for wine has led him, in the absence of Polyphemus, to agree to give in exchange for a bottle of wine some of the Cyclops' food. The latter, unfortunately for old Silenus, returns as the transfer is about to be made, and catches all parties concerned in the very act. Silenus, however, is not dismayed at this development. The fertility in concocting schemes, which is another characteristic of the old in Euripides (see pp. 60-65), stands him well in hand. He extricates himself from his dilemma by a piece of amazing mental gymnastics. He declares that the meat and cheese which the Cyclops sees had been stolen by the strangers after he himself had been overpowered and beaten black and blue." And when the strangers try to present their side of the case, old Silenus shuts them up good and short by a voluble appeal to all the gods and goddesses to attest his innocence. ${ }^{3}$ In the month of no other man than an old man would this display of religions fervor have been half so comic or pathetic. ${ }^{4}$

In the Iph. Aul. it is the old servant who tells Agamemnon that the gods will have their way in spite of men.

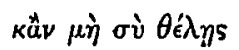

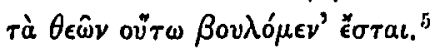

And in the same play Agamemnon's father-in-law, Tyndareus, "being an old man and reverencing the sacred customs," so we are told, interposed to allay the family feud.

$$
\text { 1Phœn. 1187-8. 2Cycl. 288. 3Cycl. 262-8. }
$$

4 Cf. also the frequency with which Silenus calls on the gods, 555, 558, 560, et al. $\quad$ "Iph. Aul. 32-3.

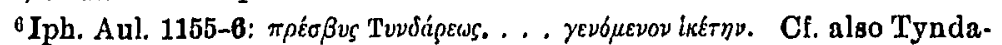
reus' making the suitors swear to abide by the decision of Helen. 
In the Hippolytus the old ${ }^{2}$ servant is the instrumentality Euripides adopts to urge Hippolytus to let his religion extend to all the gods - even to Aphrodite," adding that the gods must have their due. ${ }^{3}$ And as is customary, when Hippolytus, a young man, proves himself recalcitrant and stubborn, the old men have recourse to prayer, declaring in their prayer of intercession that his irreligion is due to youth." And the old nurse, to break down Phxdra's resistance, appeals to the incestuous lores of Zeus and the other immortals, pretending at any rate implicit belief in those stories.

In the Trojan Women Hecuba is the devout old woman we should expect to find. She is shocked at the godlessness of Agamemnon in marying Cassandra in the face of the prohibition of the gods.

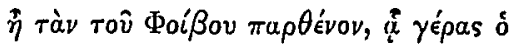

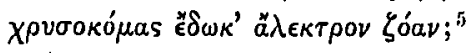

She attributes the failure of the Trojan arms to the gods $;^{6}$ and her strange prayer (lines 884-8), far from being in Ler mouth a sign of hel incredulity, is the joyous exclamation of triumphant faith. Helen, her enemy, the author of all her wretchedness, is dragged off the stage by the hair to what will soon be death. This was the consummation Fecuba had striven for. The accoimplishment of her purpose shook her soul to its depths, and she saw in Helen's death the just decree of a just god. Her deep religious sense is touched; a strange cry ${ }^{\top}$ due to her excitement, escapes her, but the burden of that cry is exultant faith. Her character thruout the play is consistently religious. A study of her reply (Jines 686-708) to Andromache's speech (634-683) reveals this well. Andromache is_utterly hopeless at the lot which has come upon her, and contends that death, which is nothing but forgetfulness, ${ }^{8}$ is far better than life. Hecuba, on the other hand, comparing her condition to a storm at sea, ad-

\footnotetext{
1Hip. 114. 2Hip. 99. 3Hip. 107. 4Hip. 118. 5Tro. 252. oTro. 608-9, 343.

TMenelaus says (889) when he hears her prayer:

$\gg$ Tro. 636-7.

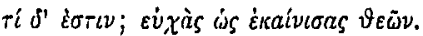

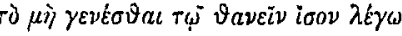

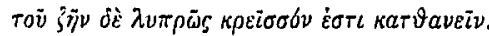

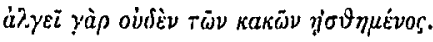


mits that she too is distressed; but since it is God's work, ${ }^{1}$ she takes courage and looks with hope to the future. Compare the closing mords of both." Note the difference. It is due to Hecuba's firm belief in the justice of the gods. She cannot be utterly cast down. On the other hand thruout Andromache's stay upon the stage she evinces a hardness of heart towards them. Her last words as she goes sweeping off are indicative: "No use to fight against the destroying gods." Hecuba's pं She rushes to their defense first." Notice further that it is Hecuba, an old woman, who is put forward as the champion of the gods. She strips away seusuality from them ${ }^{5}$ and declares that the evil in men's nature is due to themselves and in no wise to the gods. ${ }^{6}$ She vindicates nobly the proper attitude of the old towards the gods and atones for any hasty exclamation which may have been wrung from her under accumulated sorrow. Aud at the very end of the play when every. thing has been swept away from her and her city is crumbling to its fall her sorrowful lamentation is: "Oh, the temples of the gods and my city dear!"'s

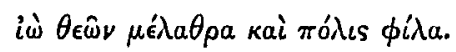

In the Hercules Furens, Amphitryon and the chorus are the

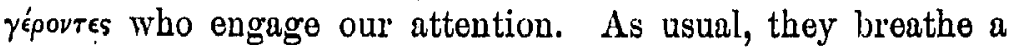
deep religious feeling. Amphitryon, who speaks the prologue, is a suppliant like Iolaus in the Heraclidie, at the altar of Zeus Soter,

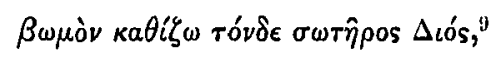

seeking there safety from the murderous desires of his enemy. Amphitryon believes the old stories of the gods, and is put forward as the defender of them against the onslaughts ${ }^{10}$ of the blasphemer, Lycus. He appeals to these old stories as proof of Hercules' divinity and prowess. ${ }^{11}$ And he further evinces his

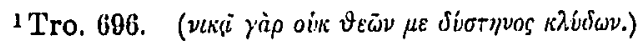

2Tro. 681-3, 697-705. 3Tro. 775-7.

+Tro. 969-70.

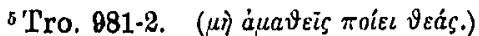

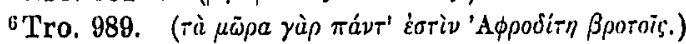

iSee page 23. 'Tro. 1317.

oH. F. 48 . 10H. F. 144-64, especially 149-50. ${ }^{1} \mathrm{H}$. F. 174-6. 
deep religious sense by exhorting Lycus to act gently so that the gods may act gently by him.

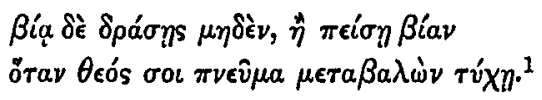

He has a firm belief in the entity of Zeus, for he calls on him (possibly with a little impatience) to help, and that quite speedily.' But nothing shows Amphitryon's religious sense better than lines 599-605. Hercules has just returned unexpectedly from Hades. All is joy at his arrival, for it means salvation for his wife, father, and children, and death to their common enemy. Everywhere is there hilarity, joyousness, and self-confidence. At this juncture, when every one else has religious thots about as far as possible from them, Amphitryon, the old man, following the religious bent of his nature, commands Hercules to perform his obligations to the gods and get their help in the impending crisis. ${ }^{3}$

The chorus of old men, too, thruout the play are on the side of the accepted beliefs. Especially significant are lines 801-6. "Beyond expectation even the tale of thy marriage in days agone is shown to me true. Time has convinced me.": The passage clearly shows that Euripides conceived old age as the quieter of doubts. As old age comes on, the old become more religious, cease to speculate, and accept the traditional beliefs.

In the Andromache the very first reference to an old person is in connection with the religious zeal of Peleus. Andromache has taken refuge at the altar of Thetis not so much because of lier own trust as because, so she tells us, old Peleus, with his household, reveres the goddess so. She hopes to profit by Peleus' religious zeal." And thruout the play old Peleus himself fully sustains the religious reputation with which Andromache invests him. No word of censure of the gods escapes him even in the midst of his greatest distress. In summing up the agencies thru whose influence he exercises lordship over the

\footnotetext{
${ }^{1}$ H. F. 215-16. $\quad$ 2H. F. 498-500. 3H. F. 604-5.

4Cf. Heraclidi 871-2, where Alcmene says that tho formerty she had disbelieved, now she knows that Hercules is a god.

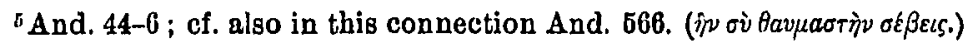


land of Phthia he places the gods first. ${ }^{1}$ And his very last words as he leaves the stage at the conclusion of the drama contain a reference to the correct attitude of the gods. ${ }^{2}$

In the Electra the $\pi \rho^{\prime} \sigma \beta v s$, tho on the stage but a short while, displays this religious sense in a marked manner. In fact, even before he appears Electra says to the avirovprós that when the old fellow hears of Orestes' return he will rejoice and thank God.

$$
\dot{\eta} \sigma \theta \dot{\eta} \sigma \epsilon \tau a i \text { }
$$

This is a touch true to the old man's nature; for his first words when he recognizes Orestes are:

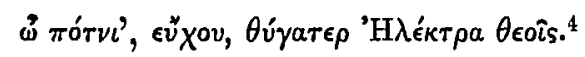

In the Helen the righteousness of old Protens is thruout the play thrown into sharp contrast with the godlessness of the young Theoclymenus. It is hardly too much to say that the entire movement of the drama (up to line 1165) hinges upon the contrast between the action which righteons Proteus would take, were he alive, and that action which the godless

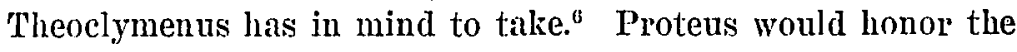
gods and respect virtue; Theoclymenus does neither. He even proposes to kill his own sister when he finds that sle has thwarted his licentious purpose ${ }^{7}$ and is stopped only by the interposition of heaven.

The beginning of the speech of the old messenger (711) is an interesting passage. Helen and Menelaus had in the recognition scene imnediately preceding been inclined to censure the gods for their harshness and deceit towards themselves. ${ }^{8}$ And this, too, in spite of the fact that they evince elsewhere in this play an unusual degree of piety. In fine contrast to this hardly concealed criticism of the gods by Helen and Menelaus is the speech of the old messenger. He tells them both: "God works in a mysterious way; and tho he does turn things upside down, yet he does it for some good purpose."

1And. 759-60. 2And, 1283 (bracketed by Murray). BElectra 415. 4 Electra 563. 5Hel. 962.

'Cf. Menelaus' plea for life (961-90). The crux of this plea is the ever-recurring crux of the play. Cf. 1002-4, 1028-9.

7Hel. 1624-6. 8Hel. 667-97. OHel. 711-.


In the Orestes Tyndareus is shocked at Menelaus for violating the sacred customs of Greece in speaking to the bloodstained Orestes-a thing which religion forbade. ${ }^{1}$ And the burden of his speech (491-540) is the necessity of observing law, both religious and civil. Note especially 518-25, and of these mark the following lines (523-25) :

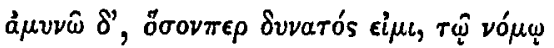

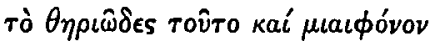

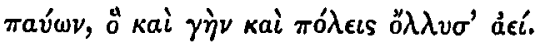

His final appeal to Menelaus to have nothing to do with Orestes is a religious appeal."

In the Phœnissæ the old pedagogue, tho sJmpathizing with Eteocles, says that Polynices has justice on his side, and his fear is that the gods will see it that way. ${ }^{3}$ Also old Iocasta, tho inclined to grumble at fate, ${ }^{*}$ declares that God's visitations must be borne: $\delta \epsilon \hat{\imath} \phi e^{\prime} \rho \epsilon \nu \tau \grave{\alpha} \tau \hat{\omega} \nu \theta \epsilon \hat{\omega} \nu .{ }^{5}$ She ends her long exhortation to the boys to forget their past disagreements with a fervent, "May God help you!" Nothing could exceed the deep religious tones of the following:

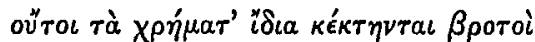

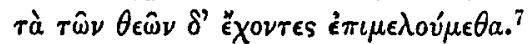

A noteworthy example of the godlessness of youth and the reverence of age is found in Phœn. 771-3. Eteocles is ashamed to meet Tiresins because of his many scoffing criticisms of the soothsayer's art. He asks Creon, therefore, to meet and talk with Tiresias for him. "Tiresias," he says, "will talk to you gladly, but me he hates because of my many strictures on his art."

This reverence for things religious which Eteocles here attributes to Creon, the old uncle displays thruout the play.

1Ores. 481; cf. also line 485.

2Ores. 624. Cf. also Ores. 627-8. In these lines he recognizes himself as being on the side of religion.

3Phœn. 154-5. $\quad$ iPhœe. 86; also 379 et pas. $\quad$ "Phœn. 382.

oPhœn. 467-8. TPhœn. 555-6.

sThis character of Eteocles is maintained. It is he and his brother who think they can outwit the gods $(872-4)$. Tiresias in horror tried to prevent their wickedness. 
Cf. his desire to propitiate the death god:

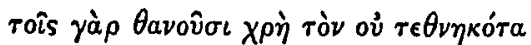

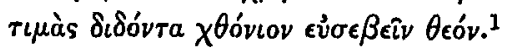

Cf. also his words when he exiles CEdipus. ${ }^{2}$

As it is with the other old characters of this play, the Phœnician Maidens (Jocasta, the Pedagogue, Creon), so it is with old GEdipus himself. Tho on the stage but a short time, yet that time is sufficient for the poet to bring out the religious element which we have shown he conceired to be one of the fundamental attributes of senile nature. CEdipus' whole attitude towards the gods may be seen in the closing words of the drama where the old man, as he goes ofl the stage into exile, says:

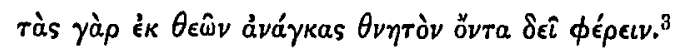

In the Medea the messenger, in describing the death of Creusa, says that as soon as Creusa's strange actions were noticed it was an old servant who, thinking her mad, raised from motives of superstitious piety a powerful cry. ${ }^{4}$ And the old father's first thot after falling down and embracing the young body of his daughter was a religious one:

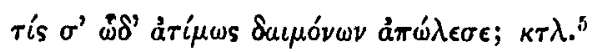

In the Melanippe it is Helen, scnex decrepitus, ${ }^{0}$ who, from motives of religious zeal, advised and at last persuaded FEolus, tho much against his will, to burn his children.

\section{YOUNGER CHARACTERS.}

This conception of the old which Euripides had-viz., that their natures were essentially religious and that carping criticism of Divinity and divine affairs could not fittingly be put into their mouth-becomes clearer when we consider the at-

1Phœn. 1320-1. 2Phœn. 1592-4. 3Phœn. 1763. 4Med. 1171-3.

"Med. 1208-10. oEuripides Restitutus, Hartung, Vol. I., p. 117.

7The old servant's appellation, kakis, applied to Apollo in Ion $\mathbf{8 5 2}$ and his declaration of 960 do not contradict this statement. Here the old man is so shocked at Creusa's confession of motherhood and at the neglect she has suffered at Apollo's hands that he is not really himself. He simply acquiesces in Creusa's characterization of the god as a knave. He is shortly so overcome that he covers his face with his hands and weeps. See also "Additional Note," p. $23 \mathrm{ff}$. 
titude his younger characters assume in such matters. ${ }^{1}$ Here a very torrent of distrust and speculation meets us, quite justifying Aristophanes in his criticism that Euripides persuaded men that there were no gods. ${ }^{2}$ Euripides, the advanced thinker and speculator, used the younger characters of his dramas thru whom to attack the, to him, impossible beliefs of his day. If we take up and consider some of the younger characters, this becomes apparent.

In the Ion we have a young man nineteen or twenty years old who has, from earliest infancy, lived at Delphi, in the service of Apollo. He is a religious enthusiast, and the play opens with several choral odes chanted by him in praise of Apollo and his service. They breathe a deep sense of satisfaction and delight:" One conld hardly imagine a more unlikely agency than this religious boy for the promulgation of bitter denunciations of God and things divine. Yet this very thing happens, for even while he is engaged in his songs and service a woman approaches the temple oppressed with great grief. She accuses Apollo of wrouging her some nineteen years before, and of abandoning both her and her child. She is still young and hurls defiance at the god. "Where can people look for justice," she wants to know, "if the gods are full of wickedness?"

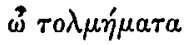

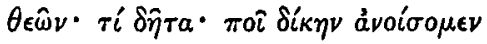

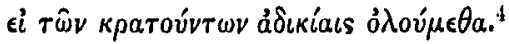

1We have, as Dr. Verrall points out (Euripides: The Rationalist, p. 104), "express evidence" to show with what eager zest, all the stronger perhaps because of the flavor of impiety, the younger men of the poet's day scrutinized his works. Arist. Frogs., 954-7:

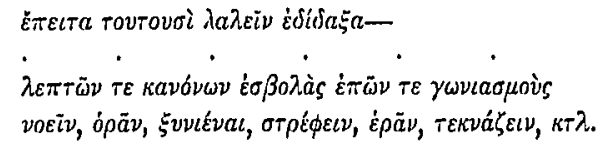

That is, the younger men were especially given to the discussion of these matters. Hence Euripides thus represents them in his plays. Not all the younger characters are cavillers, but all the carping criticism of the gods is spoken by the young. But see "Additional Note," p. 23 .

$$
\text { 2Thesm. } 450 . \quad \text { 3Ion. 12S-9, 152-3, etc. } \quad \text { Ion 253-4. }
$$


As we might expect, Ion is horrified at the first words of Creusa impugning this terrible crime against Apollo. He fiercely cries out: "Speak not so, O woman!" And upon Creusa's reiteration of the charge he sharply says: "Such a thing as you aver against the god is not possible." It is not long, however, before Ion is forced to concede by reason of the weight of testimony Creusa adduces that the business has a suspicious look. ${ }^{3}$ Soon he is convinced that Apollo is really guilty. He then forgets his former delight in his service and branches out into a lengthy lecture to the god on morality. "Force maids! Beget children only to abandon them! Oh, do not so, Apollo! Follow virtue, for thou art strong! The gods punish man if he is wicked. It is not fair to damn men for immorality if the gods blaze the way.":

This is the beginning. From now on till the end of the play this young man, who had started out as a religious devotee, is the mouthpiece for many a harsh and hard statement against the gods. He vies with Creusa in his vituperations and criticism of the gods. He criticises the laws they have made, saying that they have made them with but little sense. $\mathrm{He}$ has the presumption to say what the divine laws should be. ${ }^{6}$ He attacks the sacred rite of asylum-a rite which extended its protection to young and old, to good and bad-and he proceeds to such a degree of shamelessness that he is on the point of putting his creed into practice; for in his fury he wants to tear Creusa from the altar and to hurl her upon the rocks. ${ }^{7}$ Creusa plainly tells the god (see also p. 16) that

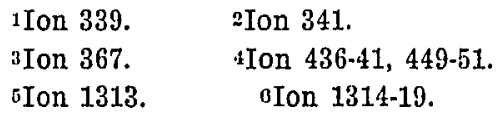

7Ion 1266-7, 1275-6. Liliewise it is Copreus who, in the Heracl. (99-100), ridicules the rite of asylum and tries to pull- the suppliants loose. Also Orestes, in the I. T. (119), gladly concurs in Pylades' suggestion to make a bold attack upon the altar during the coming night. Cf. also Lycus in the H. F. He wants to tear Amphitryon, etc., from the altar. In the Dictys, King Polydectes order's Danaë to be torn from the altar, whither she had fled for protection. (Hartung, Vol. I., p. 371.) In view of these examples of the disregard of 
he is unjust, ${ }^{1}$ and later when she recounts the story of her wrong with bitterest hate she berates the god, accusing him of rape, ${ }^{2}$ of abandoning his child, ${ }^{3}$ and she ends by declaring that her base lover:" has forfeited by his baseness the love and even the respect of all he holds most dear."

It is interesting to note that Apollo sends Athena at the end of the play to cut the knot instead of coming himself for fear (see lines 1557-8) that, had he come himself, he would have been severely rebuked by the youtliful Ion and by his mother, Creusa. So bold was youth that it would censure a god to his face!

As in the Ion, so thruout the dramas of Euripides it is the young thru whom the poet accomplishes the purpose of his religious teaching." Perhaps it would be better to say thru whom he introduces his advanced religious conceptions-his religious innovations.

Polymnestor", in the Hecuba, accuses the gods of turning" things "topsy-turvy" so as to get men to worship them in their ignorance (958 fi:). In the Bacche it is the godless Pentheus, a young man, who is contrasted with the religious Cadmus and Tiresias, old men. He is the caviller and opposer of religion, carrying his opposition to the point of absolute

asylum by the young, it is likely that Frag. Incert. (Nauck), 1036, was. spolien by one of the younger characters.

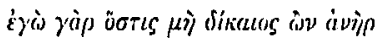

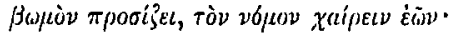

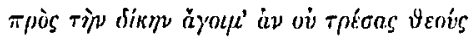

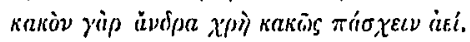

Hartung, however, assigns it to Atreus in the Clessa (p. 178, Vol. I.). IIon 384. $\quad$ IIon $894 . \quad$ "Ion 902 . *Ion 912 .

Ion 919-22. In the same strain the chorus says they are ashamed of the much-lauded god (1074).

oThis has been variously described as a purpose to teach "human nature as the source of moral ideas." (W. H. S. Jones, in The Moral Standpoint of Euripides, p. 21.) And again as a purpose "to arouse reflection about the value of certain usages . . . previously observed blindly and without discrimination." (Decharme, p. 73.) And again as that of a "notorious rationalist, compelled by the circumstances of the time to use for his organ of expression a stage appropriated by origin and custom to the exhibition of miraculous legend." (Verrall, Euripides: The Rationalist, p. 166.) 
insult and vileness. He sees only licentiousness-not religionin the devotion of the maids and mother's of Thebes. ${ }^{1}$ He accuses the seer Tiresias of a mercenary motive in his zeal for the new religion, ${ }^{2}$ and threatens him with chains and prison. ${ }^{3}$ He brutally and vulgarly rebuft's his old grandfather when in his zeal he tries to put a wreath upon the head of Pentheus. ${ }^{4}$ And he caps the climax of his impiety by dispatching one of his servants to overthrow the seats of the soothsayers and to scatter their paraphernalia to the winds." It is no wonder that the chorus, amazed at these and similar outhursts of impiety, cry out: "Oh, the impiety! Friend, thou dost not l'evere the gods!"

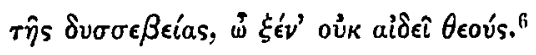

It is the youthful Hippolytus now whom an oath, a thing which the Greeks "regarded as a divine institution," sits lightly. Also it is Agamemnon in the Iph. Anl. who declares that some oaths need not be kept. It is this same Agamemnon who, in another place, says of soothsayers that the whole tribe is evil.

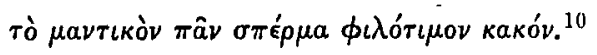

And Menelaus even proposes to kill old Calchas as an easy way to get rid of his troublesome oracles. ${ }^{11}$ Achilles says that soothsayers are liars'12 for the most part and speak the truth but seldom. ${ }^{13}$ Orestes in the I. T. says that Apollo, tho called wise, is as unreliable as evasive dreams. ${ }^{14}$ Also Pentheus in the Baccher, ${ }^{15}$ Theseus in the Hippolytus, ${ }^{10}$ Orestes in the Electra, ${ }^{17}$ -none of these being old men-all snap their finger in the face of the soothsayers and forcibly discredit them. Further, it is notewortly thit, altho Luripides everywhere ${ }^{18}$ expresses

1 Bac. 221-5. Cf. also 487. "Bac. 255-7. "Bac. 258-9. „Bac. 343-4. Bac. 346-50. "Bac. 263. iDecharme, p. 72. "Hipp. 612.

OI. A. 393-5. 10I. A. 520. 11I. A. 519.

12In the Helen ( $744 \mathrm{ff}$.) the messenger, an old man, voices the same sentiments. But see p. $24 . \quad$ 1:I. A. 956-8.

14T. 570-1. Tho Orestes uses the plural, he really jefer's to Apollo.

1 B Bac. $255 . \quad 10 \mathrm{Hip}$ 1058-9. 17Elec. 400.

16The only exception is Thesens in the Supplices $(155-9 ; 211-13)$. And Thesus was, as we have said (p. 7), religious only for spectacular purposes and on occasion. 
his contempt for divination and does it, as we have seen, thru the younger of his characters, yet in the Phœnician Maidens he invests the old prophet, Tiresias, with dignity and nobility. It would ill beseem the old Tiresias to be a vaunting caviller.

In the Troades, Agamemnon is the godless wretch who yields to his passion and, "setting aside his duty to the god and religious reverence,"

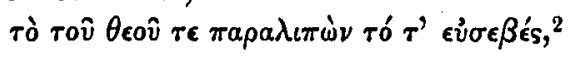

takes as his concubine, Cassandra, to whom Apollo himself had granted the boon of perpetual virginity.

It is Helen who sneeringly declares that Zeus is the victim of his passions:

$$
\text { (Zeús) }
$$

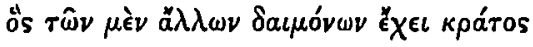

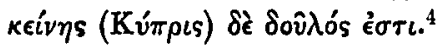

And odes beginning with lines 799 and 1060, sung by young women, are nothing but reproaches of Zeus for his neglect.

In the H. F., Lycus, the young usurping king of Thebes (like Copreus in the Heraclidx, and like Pentheus in the Bacchæ), is very sarcastic ${ }^{5}$ with respect to Hercules' claim of divinity. ${ }^{6}$ He ridicules his labors and denies that they give any trace of his divine origin or as even meriting recognition, ${ }^{7}$ impugns his valor, ${ }^{8}$ and even says he always kept a weather eye open on the side of flight. ${ }^{\circ}$ Lycus regards Hercules so little that he is bent on murdering his reputed father, Amphitryon, his wife, Megara, and his children. ${ }^{10}$ He is exceedingly impatient at them for temporarily thwarting his purpose by seeking safety at the altar. ${ }^{11}$ Further, he is so indifferent towards the gods that he haughtily order's the suppliants smoked out, ${ }^{12}$ and later, when Amphitryon refuses to go in and bring them out, he himself says: "Oh, well; I'll go myself since $I$ am wholly with. out scruples." $"$ It is no wonder that the chorus of old men call Lycus ávóotov kápa. ${ }^{14}$

1Paley, note to line 43. 2Tro. 43. 3Tro. 253: 41-2. 4Tro. 949-50. бH. F. 145-6. ०H. F. 151. 7H. F. 155-6. 8H. F. $157 . \quad$ oH. F. 161. 10H. F. 168-9. 11H. F. 140-6.

12H. F. 240-4. Cf. Andromache (257), where Hermione (a young person) attempts the same thing. $\quad 13 \mathrm{H}$. F. $722-4$. 14H. F. 255. 
In the Andromache, the young Hermione is the proud contemner of the gods. In her superciliousness and vanity she recognizes no obstacles to her will. She declares that the temple of Thetis shall not stand in her way. ${ }^{1}$ In fact, she adds, no altar, no temple, shall do so. ${ }^{2}$ And she threatens, as Lycus in the H. F., to smoke Andromache from the protecting altar. ${ }^{3}$ It is this Hermione who finally decrees the death of the youthful Molossus, ${ }^{*}$ caring not a whit for the desecrated altar of the gods nor for the fact that the murder which she decrees is, as the chorus says, "utterly godless." With her father, Menelaus, she snaps her finger in the face of the gods and lays herself open to the same charge of no longer believing in the justice or existence of Divinity." So vindictive, so unjust, so irreligious is she that Euripides, contemplating these traits of youth, makes Andromache say: "All, how bad a thing is youth!"' Note also that it is the messenger who scornfully denounces Apollo. ${ }^{8}$

In the Helen the heroine doubts the story of Zeus' stolen intercourse with Leda. ${ }^{0}$ Theoclymenus is thruout a godless young man. Note also the words of the chorus of maidens. ${ }^{10}$

In the Electra, Orestes attacks oracles, ${ }^{11}$ the chorus of young women say they do not put much credence in the legend of Atreus and Thyestes,

$$
\begin{aligned}
& \tau \grave{\alpha} \nu \hat{\delta \epsilon} \pi \dot{\imath} \sigma \tau \iota \nu
\end{aligned}
$$

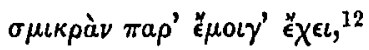

and Orestes bitterly complains that Apollo is guilty of a wicked oracle in that he has appointed him to kill his mother whom he ought never to have killed. ${ }^{13}$ And in answer to Electra's suggestion that Apollo can do no wrong he blasphemously exclaims: "I never will believe that this oracle is a just one."

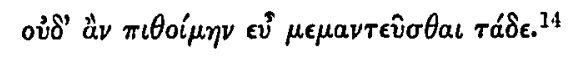

In the Orestes, Electra in the prologue, while recounting the calamitous history of Tantalus, significantly adds, w's $\lambda \dot{\epsilon} \gamma o v \sigma \iota$, twice within four lines (5-9). Porson, quoted by Paley

1And. 161. 2And. 162. 3And. 257. 4And. 519. Cf. 431-2.

5 And. 491. OAnd. 439. 7And. 184. sAnd. 1161-5. OHel. 21.

10Hel. 1137-43. 11El. 399-400. 12El. 737. 13El. 971: 973. 14El. 981. 
(note to line 7), says: "Innuit Electram parum credulam esse." Helen says in line $\mathbf{7 6}$ of the Orestes that she blames Phœbus, not Orestes, for the sin of Clytemnestra's murder; ${ }^{1}$ and Orestes in a perfectly sane moment, and therefore fully conscious of what he says, declares:

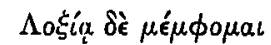

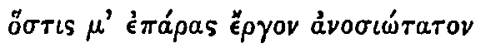

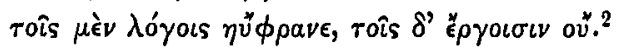

Note also lines 394,414 , and 416 . Observe the response (line 417) of Menelaus to line 416. Both Menelaus and Orestes are continually bitter towards Apollo, reproaching him for the oracle and for his delay in sending help; tho now and then Orestes arises to full trust in him. Of. $418-420$.

In the Melanippe it is the youthful Melanippe who in the prologue says:

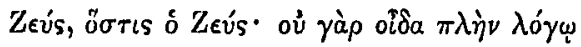

$$
\begin{aligned}
& \kappa \lambda v^{\omega} \omega \nu .{ }^{3}
\end{aligned}
$$

These words were so blasphemous that Euripides, to allay the storm which followed, had to change them. ${ }^{*}$ Likewise it is Bellerophon who was so godless thruout the play which bears his name that betore the end of the piece such a tumult arose in the theater that Euripides himself had to appear on the stage and quiet the people."

In view of all these examples of outspoken questionings on the part of the young as to the nature of Zeus and the other gods, it is likely that Frag. Incert. 935 (Nauck) should be assigned to some one of the younger characters. ${ }^{6}$

From the preceding discussion, therefore, it seems fair in conclusion to sum up the matter thus: If Euripides rov̀s äyopas

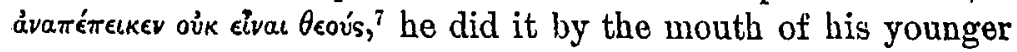
characters. The old have a decided religious bent.

1Cf. Electra's words in Orestes, 161-5. 2Or. 285-7. $\quad$ 3Frag. 483. 4Euripides Restitutus, Hartung, Vol. I., p. 114.

EEuripides Restitutus, Hartung, Vol. I., p. 399.

nHartung (Vol. I., p. 179), however, assigns it to Atreus in the Cressæ. iAristoph. Thesm., 450. 


\section{ADDITIONAI NOTE.}

Troades, lines 468-9:

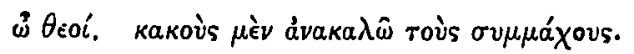

Troades, line 1280:

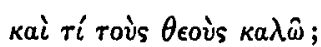

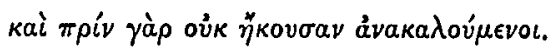

Troades, line 1240:

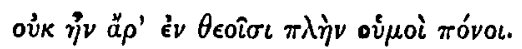

In the light of our study we should have expected to find these words in the mouth of a younger character. We have shown, however (pp. 10-11), that Hecuba's character is normal. In these three passages she evinces those other characteristics of the old, garrulity and excitability, ${ }^{1}$ being led by these traits into unseemly remarks. She is under great excitement thruout the play. Her city is taken, and is to be burned (1260) ; Astyanax, her grandson and ouly hope, is tor'n from her embrace and killed (720) and then returned to her for burial (1147), etc. Under these accumulated blows she yields in these three passages to her emotions and forgets herself. Her emotional and garrulous characteristics here predominate over her religious traits. It is but momentary, however, for immediately after line 469 she remarks: "However, I like to pray just the same."

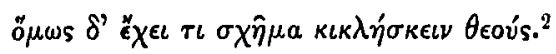

So much for lines 468-9. Lines 1280-1 are recognized by Talthybius as not expressing Hecuba's real sentiments, for he immediately replies: "Thy misfortunes have upset thy mind."

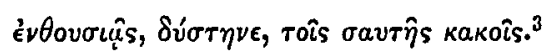

While Hecuba's very next utterance is a fervent prayer to Zeus."

This again for lines 1280-1. Lines $1240-2$ are immediately followed by a reflection (1242-) on the divine purpose of her sorrow, which reflection brings her consolation. So that none

'See pp. 39 ff., 52 ff. $\quad$ 2Tro. $470 . \quad$ 3Tro. $1284 . \quad \pm$ Tro. 1287. 
of these passages, tho a little irregular, are in reality atheistical.

Note also H. F. 212, 341-7, 501.

Zeus' identity and existence are not once questioned in these lines; in fact, his existence may be said to be the key. note of all of them. The querulous tone is due to an excessive depression over the distressing state of his affairs. And while we would expect to find them in the mouth of younger people, they do not alfect Amphitryon's religious character. Line 212 is followed directly (215) by a pious remark and (501) errs on the side of excessive religious zeal. The long passage (34I7) is redolent with belief: in the old stories; tho, as we said above, the querulous tone would usually. be put into a younger mouth. Amphitryon is provoked beyond the power of selfcontrol by Zeus' continned neglect.

Helen, lines 744-757.

This bitter attack on oracles is spoken by an old messenger. Here the well-known talkativeness of heralds and Euripides' hatred of the class ${ }^{1}$ may be urged as explaining (so also Hec. 488 ff. and Ores. 954-6) the unusual phenomenon of an old man's being a caviller. And yet this outburst, bitter as it is, is directed against impositions and deceptions of men rather than the existence and identity of God (cf. lines 753-4). For this old messenger was a pious old soul and had a clear and just conception (as we have shown on p. 13) of the activity of Deity in the affairs of men. His talkativeness gets in this instance the better of his discretion.

\section{GARRULITY.}

The next characteristic of old people which we may note in the dramas of Euripides is their loquacity and excessive garrulity. This very marked trait of character in the old of Euripides is closely associated with three other traits no less common than that of garrulity, but which stand in some such relation to it as cause stands to effect. Garrulity is the resultant of these other traits. It is the compound of which they are the component parts. They become, therefore, for our purpose 
the sub-sections of a general head. Topically arranged, the proposition assumes the following form:

\section{GarRulity on Loquacity.}

(a) Bodily infirmity, with its consequent weakness and loss of power, combined with an ardent desire to be young and strong.

(b) Excitability of temper, bordering sometimes upon irascibility.

(c) A conviction that to give admonition to their juniors was the necessary duty of age.

Before proceeding to the discussion of these points I desire to call attention again to the fact that $(a),(b),(c)$ are not to be considered as secondary-i. e., minor traits of character, merely because they are arranged as sub-heads. They are bold, glaring, ever-recurring traits with which Euripides has endowed his old characters. We have arranged them as we have merely to facilitate the discussion and because they are the traits which logically explain, or, to put it otherwise, which cause garrulity.

The first topic, therefore, under this head which we will discuss is:

(a) Bodily Infiraity, witu I'ss Consequent Weateness and Loss of Power, Conbined with an Arden't Desire to Be Young and S'rrong.

This natural result of age, bodily infirmity, is very prominent in the old characters of Euripides. They are weak and balting in body and querulous of the restraints which this bodily infirmity imposes upon them. They would be other than they are; they would still take their wonted part in the activities of the time and place in which they are, but the limitation of advancing years, with the inroad which these years make upon their bodily strength, prevents. They recognize with bitterness their impotence and yield, because they must, and not because they will, their places to younger actors. old Amplitryon's words in the Mad Hercules show this trait in excellent wise. ${ }^{1}$

1H. F. 228-35. 
It is in this rein that he speaks whenever he refers to himself, always showing impatience and scorn at his impotent age.

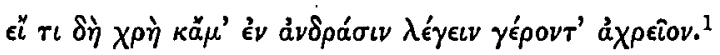

"A useless old man, me! A real man? fie!"

The chorus of old men, who have come to lament ${ }^{2}$ with Amphitryon, with bitter words emphasize at all times this feebleness of age. Their first words as they come upon the stage are indicative:

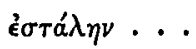

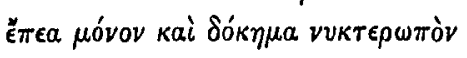

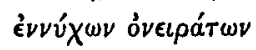

$$
\begin{aligned}
& \tau \rho \circ \mu \epsilon \rho \grave{\alpha} \mu \grave{\epsilon} \nu, \dot{a} \lambda \lambda^{\prime} \grave{o} \mu \omega \varsigma \text { } \pi \rho{ }^{\prime} \theta v \mu a .{ }^{3}
\end{aligned}
$$

"I have come, a mere voice, a gloomy-visaged fancy of midnight dreams, with trembling yet with zealous foot."

Note the very pathetic appeal of the chorus to its powerless right hand to take the spear and drive the usurper from the land. ${ }^{*}$ Note in the above lines the bitterness he feels at the thot of his weakness. Of the same tenor are lines 312-14, 43641.

Very noteworthy in this connection is the choral ode beginning with line 637 . It gives us a clear insight into Euripides' own thots on this subject, for he is here speaking subjectively. The words he puts into the mouth of the old chorus express his own opinion about this phase of old age." He says:

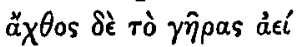

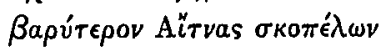

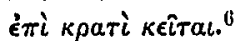

In the Troades old Hecuba, when wondering whose slave she is to be, calls herself a "drone" ( $\eta \phi \eta v),{ }^{7}$ "the shadow of a

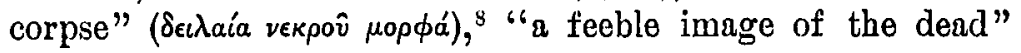

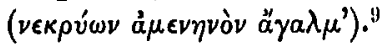

1H. F. $41 . \quad{ }^{2}$ H. F. 109. $\gamma o ́ \omega \nu$ áousós. $\quad$ :H. F. 109-13. 4H. F. 268-72.

In Herculis tempore constituendo sequor Wilamow. Her, 1, p. 137 sqq.; tamen noluerim ante annum 420 eam ponere, quia tum nondum adeo aefate provectum Euripidem fuisse patet, ut senectutem queri posset. Conradus Haym: De puerorum in re scaenica Graecorum partibus. Dis. Phil. Hal., Vol. XIII., Par. IV., p. 284, N. 3.

听. F. 637-40. Cf. also lines 649-54. TTro. 191. sTro. 192.

OTro. 193. Cf. with these words of Hecuba, Frag. AEolus, 25. 
In the Andromache, Andromache wishes for Peleus in her time of trouble, whereat the old serrant responds: "He's an old one ; too old to help even if present."

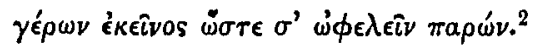

Again, when Peleus is advancing to deliver the suppliants from the hand of Menelaus, he says: "Now, if ever, is there need that I feel young again." ${ }^{\prime \prime}$ Later on in the play Hermione tells Orestes that her father has gone back to Sparta, his purpose being given up because of Peleus' opposition. Orestes exclaims: "What! He wasu't conquered by that old fellow, was he?"' Further on Hermione expresses fear that Peleus may overtake them in flight. Orestes responds: "Don't fear that old fellow." And plainly implies: "I am fully able to defend you against him."

In the Ion the weakness of age and the desire to appear strong are again referred to. Creusa summous the old pedagogue, who is her ally, not to yield to fatigue as he approaches the temple ( 745$)$. The old man braces himself up and proudly answers: "It won't be my fault if I do." He immediately realizes his condition, however", for he adds: "I'm but half $\mathrm{my}$ former self."

$$
\begin{aligned}
& \dot{\alpha} \lambda \lambda \grave{\alpha} \mu \grave{\eta} \pi \alpha \rho \hat{\eta} \varsigma \text { кóm }
\end{aligned}
$$

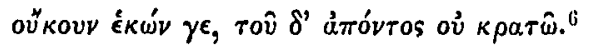

Cf. also the old pedagogue's apostrophe to his age and his desire for youth as he goes off the stage to effect the murder of Ion. Cf. also, old Phegens in the Alcmxon in Psophide when he finds out that Alcmæon has deceived him, and that the neck-

1And. $79 . \quad$ "And. 80.

3And. 552. So Paley. Murray, however (Oxford Text Eurip., Tomus 1, note to Andr. 553), says that Verrall thinks $\dot{E} \pi c_{c}$ is is said aside to tho slave, refusing his help: "In parentbesi $\dot{\varepsilon} \pi a \imath v i$ (benigne) senem dicere patat, Verrall servi auxilium abnuentem." If this interpretation be correct, old Peleus, instead of wishing for the strength of youth, feigns its presence.

4 And. 917. 5And. 993. OIon, 746.

ion 1041-4. Bayfield says (Ion, note to line 1045): "This apostrophe is far beneath the dignity of tragedy." Be this as it may, the desire for youthful strength is a trait of the old which Euripides is continually recurring to. 
lace which he asks for is not for Apollo at all, but for Alcmæon's new wife. The old fellow calls his sons, chides them for their sloth in punishing Alcmæon's perfidy, and himself wishes for the strength which the had when young, saying: "Quia nec vos (filii Phlegi) nec ille (Alcmaeon) impune inrideret meam grandievitatem."

In the Alcmene it is the sloth and weakness of age which the poet uses to produce the catastrophe. Tlepolemus, a rash youth and impatient of the weakness of Licymnius, first bitterly upbraids him for his sloth (segnitiam) and then later kills him either intentionally, being unable longer to endure the weakness of Licymnius which he thot a drawback to himself, or unintentionally because the old age of Licymnius prevented his evading the blow which Tlepolemus aimed at a slave (Hartung, Eurip. Rest., Vol. I., pp. 538-9).

In the Heraclide this characteristic of the old-feebleness of body coupled with a desire to be other than they are, to be what they once were, is well shown. Iolaus exhibits thruout such traits. When the servant of Hyllus comes in asking for Iolaus, he finds him on the floor covered with his robes and exhausted from his emotions. ${ }^{2}$ Ou hearing the servant call his name the old fellow replies: "Here I am, if my presence can avail anything:" And again: "I am an old man, weak and feeble." In spite of this recognition of his weakness, however, as soon as he hears that the Argive host is mobilizing (675-7) he wants to go out and help his friends (680-1). He is reminded that he is a helpless, weak old man whose chief oflensive weapon is the power to make grimaces (684), whose strength is a thing of the past (688), and whose presence will lend but trifling strength to the army (690). Old Iolaus indiguantly repudiates ${ }^{5}$ this estimate of his powers and

${ }^{1}$ Quoted by Hartung, Eurip. Rest., Vol. I., p. $192 . \quad$ 'Heracl. $604 \mathrm{ff}$. sHeracl. 632 . Heracl. 636.

"Alcmene is just like Iolaus. Tho she says (648),

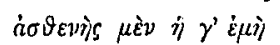
$\dot{\rho} \dot{\prime} \mu \nu \eta$

yet she boasts of her prowess and advises the servant to look well to his actions:

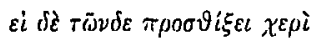

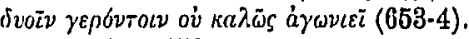

Note also her words in line 650 . 
vauntingly declares that a shield and not a grimace shall be his weapon (6S5) ; that no Argive knave shall dare to look him in the eye (687); and that neither argument nor reason shall swerve him from his fixed resolve to go (691). Notwithstanding all this boldness, and much more, the old fellow is so weak and feeble that when the armor and war accoutrements are brought out he is unable to bear the weight of them, or even to walk without help (724-8). Yet so eager is he to be strong as he once was that he deceives himself with all sorts of reasons that his present actions are needful for the success of his enterprise. His debility is great; he can hardly walk at all; yet he thinks that he is fairly running. ov้kovv ofộs $\mu$ ov

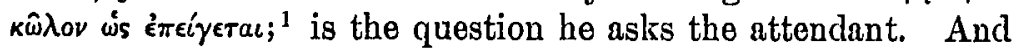
when the latter expresses doubt about it, old Iolaus boastfully replies: "Wait till I get there; then you'll see wonders."

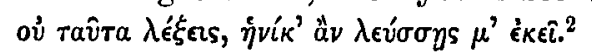

At last, howerer, a dawning consciousness seems to come to the old fellow as to his real condition, for he apostrophizes his arm in touching words."

In the Bacchie old Tiresias and Cadmus as they advance to the worship of Dionysus talk exultantly of their boyish strength ${ }^{4}$ and their power of endurance."

Euripides brings out, among other ways, this feebleness of age by introducing in many places old people all tired out and exhausted from the effort of walking or by showing what an exertion it is for them to walk at all.

In the Heracl. it is dilficult for old Iolaus to walk to battle even when accompanied by the servant (724-35).

In the Ion the pedagogue, when summoned by Creusa to come up to the oracle of Apollo (727), asks her to help him up, for the "oracle is steep" (739). Cf. also (740).

In the Electra the old servant finds it difficult to approach the house (489-90).

In the Phœnisso old Tiresias, on coming upon the stage, is exhorted by Creon to stop and take breath (850-1)."

1Heracl. 734. 2Heracl. 737. 3Heracl. 740-3. 4Bac. 190.

BBac. 187-9.

note how Tiresias, as he comes upon the stage leaning upon the arm of his daughter ( $834 \mathrm{ff}$. ), comments upon and thereby clearly brings out the wealkness and debility of age. 
In the Her. Fur. the chorus of old men exhort themselves to persevere in the toil of their approach (119).

In the Andromache, Peleus' approach is announced thus:

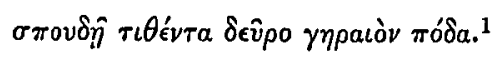

In the Alcestis Pheres' approach is similarly aunounced."

In the Bacchre old Tiresias and Cadmus lead one another with hesitating step (155-6, 193, 364; cf. p. 33).

In the Orestes old Tyndareus comes in panting, all worn

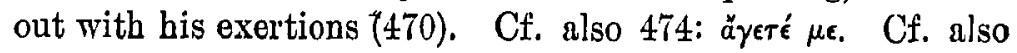

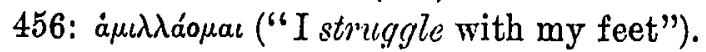

In the Hecuba (59-67) Hecuba comes in exhorting her slaves to help her, and leaning on a crooked staft. Cf. also 170-2;

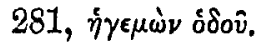

In the Supplices (172) Adrastus speaks of the suppliants thus:

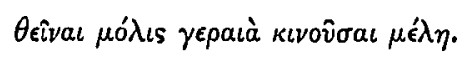

Cf. with this Tro. 1275, 1327. Also Frag. Incert. 868.

An interesting case of this slowness of movement of the old occurs in the Chresphontes. Merope is on the point of slaying her son, who, she thinks, is another person. No one is near to prevent her save an old servant, and the audience, so we are told, ${ }^{3}$ is all excitement lest the old man should not conre up soon enough to prevent the murder.:

In the Cressie, the old man who had been sent by the queen to tell Thyestes of the plans of Atreus comes forward slowly and with hesitation. Thyestes accosts him: "Quemnam te esse dicam, qui tarda in senecta."'

LUDICROUS ASPECT OF THIS TRAIT, OF THIS DESIRE TO BE YOUNG.

This desire of the old to be other than they are, to be strong and virile as when they were young, often assumes a somewhat

1And. 546. 2Alc. 611.

"Plutarch T. 11, 998.E, quoted by Hartung, Eur. Res., Vol. II., p. 50.

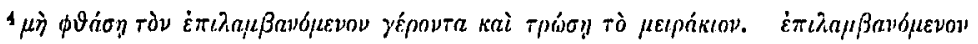
implies difficulty and slowness of action on the part of the old man.

sEnnius Frag., quoted by Hartung, Eurip. Rest., Vol. I., p. 178. 
Iudicrous aspect. Cf. in this connection old Peleus' command to the minions of Menelaus, who are dragging Andromache off the stage: "Isoose their bonds, or' some one will be set to howling;" and also his threat to split Menelaus head with his cane."

There is nothing funny in all this for old Peleus. ${ }^{3}$ He is intensely in earnest. The contrast of his bold words with his weak presence must, howerer, have been amusing to the audience. Especially must this have been so when, in answer- to Andromache's fears that some one will set upon and recapture them, the old fellow draws his bent form up as straight as he could and speaks lines $759-65 .^{*}$

In this connection we may note old Silenus in the Cyclops. He persuades himself" that he is very bold. "A fig for old Cyclops!" he says," "I'll sell his stuff! I'll give all the goods of all the Cyclops for a single cup, and then, dead drunk and fancy free, throw myself into the sea." These bold words become ridiculons in view of the craven fear of old silenus when the Cyclops comes back and finds him about to sell his goods (222 ff.).

Amusing, too, because of this trait of the old, this desire to be young, is the opening scene of the Iph. Aul. The old man whom Agamemnon summons from the palace (1) comes mumbling along with too slow a gait to suit the impatient Agamemnon. The latter exhorts him to hasten (3). The old man responds: "I'm coming as wide awake and sharp of eses as can be."

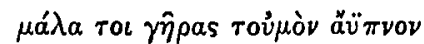

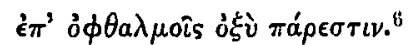

1And. 577. Cf. also the similar scene in the H. F. where the old chorus exhorts the old men of Thebes to crack the head of the usurper Lycus (254). 2And. 588.

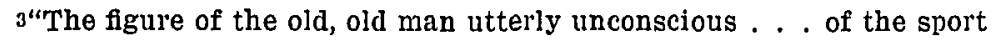
which he is affording ... has in the highest degree that stinging pathos ... which Euripides wields supremely." (Dr. Verrall, Four Plays of Euripides, p. 34 ).

4And. 758-9, 761-5. iCyc. 163-7. (After Paley.)

oI. A. 4-5. 
The weakness of age, however, gets the better of him, for, in spite of his bold words, the old fellow begins to nod and falls asleep ${ }^{1}$ during the long speech of Agamemnon (49-114).

Cf. also the scene where Iolaus is advancing with the $\theta \epsilon p a$ an to battle (Heracl. 729-40). If it were not so pathetic, it would be exceptionally comic." (For discussion of this scene, see p. $28 \mathrm{ff}$.)

1The supposition that the old fellow fell asleep during Agamemnon's speech (49-114) easily explains how it is that the old man asks (124), "How Achilles will endure the loss of his bride," when Agamemnon (106) had just told him that Achilles knew nothing of the plan. E. B. England in the introduction to his edition of this play (pp. xxiv. xxv.) rejects the idea that the old fellow could have fallen asleep during lines 49-114 on the ground that for him to have done so would have been comic. "But this is no comedy," he says. On page 82 of the text, however, in his brief outline of the third epelsodion he seems to have forgotten that "this is no comedy," for he says: "The second scene (verses 819-54) is exquisitely amusing." Now if lines \$19-\$54 be so "exquisitely amusing," why can there not be at least a little fun in lines 1-162? Again, Weil's explanation (quoted by England) of the contradiction between line 124 and line 106, on the ground that the old fellow was particularly stupid, is not borne out by facts. The old man was not stupid. Lines 133-35, where he strips the mask from Agamemnon and clearly apprehends the truth, free him from the charge of stupidity if they do not ( $I$ think they do) convict him of an especial degree of intelligence. If further confirmation of the idea that the old fellow was prone to fall asleep is wanted, we have it in lines 139-142. Agamemnon had evidently seen the old fellow dozing. Hence he felt it necessary to charge him especially in these lines not to indulge his old age on the way nor to talie any nap.

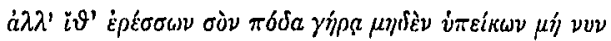

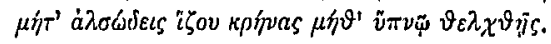

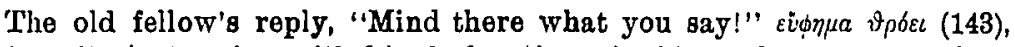
is quite in keeping with his declaration of wide-awakefulness in lines 4, 5. In fact, it might not be too much to say that the old were char. acteristically somnolent. An interesting passage occurs in the Phaëthon, Frag. 775. Phaëthon declares that he will investigate his parentage further when his old father, if once he gets over his nap, comes out. (Lines 15, 16.) And in the Peleus, Neoptolemus, who is about to go hunting, leaves old Peleus in the cave quietly sleeping, "Peleo somno quiescente." (Hartung, Eurip. Rest., Vol. I., p. 293.)

${ }_{2}^{2}$ Cf. also Decharme, p. 255: "The contrast between his senile debility and his bellicose intentions is amusing." 
An interesting passage in this connection is the first stasimon of the Heraclidæ (353 ff.). After boasting in grand style that Copreus' declaration of war would never frighten him, and after cursing Copreus by declaring that he is a ruf-

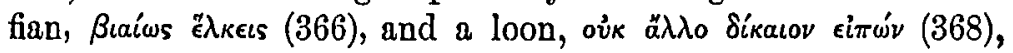
when he comes to think of the proper conduct of the war he is not so certain of his courage and quite tamely declares

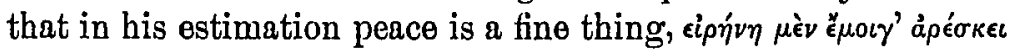
(371). After another faint flicker of boastfal courage, $\sigma o i \delta^{\prime}, \dot{\omega}$

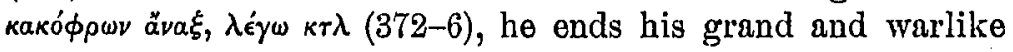
words with as pacific a prayer as it is possible to conceive of to Eurystheus to desist and not to despoil Athens with war. ${ }^{1}$

Possibly also the scene in the Bacche where Tiresias and Cadmus are hastening to the worship of the god should be noted here, especially lines 363-5. There is, tho, nothing comic in the situation for them. ${ }^{2}$

It may be also that the scene in the Dictys where, after the old fellow's ebullient anger' (p. 43) and his loud declarations that he would protect Danaë at any cost (p. 72), he hurriedly flees to the altar for protection, evoles a smile in the theater.

Under this head should possibly be mentioned also the old slave of Creusa in the Ion, who has dilliculty in coming up to the temple (738-40) and yet, after a while, wants to burn the temple and does attempt to kill Ion (1170).

1Heracl. 378-80.

2Dr. Kraus in Euripides ein bekehrter Rationalist, p. 5, thinks, however, that there is not the slightest trace of the comic, from any standpoint, in the entire scene. And I am inclined to think that he is right. 


\section{EXPLANATION OF THIS DESIRE OF THE OLD TO AP- PEAR YOUNG AND STRONG.}

The explanation of this trait of the old, this desire to appear young and strong; is to be sought in a twolold reason:

(a) The belief that the old were a useless encumbrance and that their work was done.

(b) The danger, to which the old were always liable, of being abused and maltreated.

'Taking up these reasons in the order in which they are given, we find under (a) that the words of old Iphis in the Supplices are to the point:

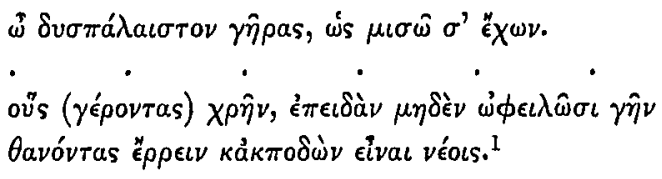

Everywhere rò $\gamma \hat{\eta} p a s$ is likewise spoken of as a hateful and wretched thing. Cf. Frikg. Polyidus 6:38.

Cf. Frag. GEnomaus 579; also Frag. Philoctetes 802. Ct. Ine. Frag. 1065̃ (Fol Greek see p. xv.). Cf. Flag. Danaë 319. Of. with this Frag. AEolus 2:?; also Phounix S04.

Cf. Frag. Antolycus 284. In the diatribe against the athletes it is said that they (the athletes) strut about, the glory

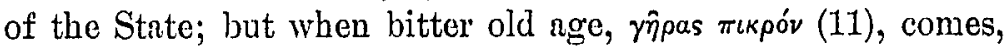
ete.

Cf. also Odyssens' words in the Cyclops. He says to the chor'us of Satyrs: "He (old silenus) is weak and given over to his passions (and cannot, therefore, help us). But you (the Satyirs) are young, and can do us nuch service.".2

Note here also Admetus' argument with his father, Pheres, in which he seeks to persunde him to die insteald of Alcestis. The whole argument is based upon this conception of encum. brance and completed work of the old:"

Cf. also Adrastus' words in the Supplices (190-2). These words clearly imply that the old were a useless encumbrance. A siguificant line occurs in H. F.:

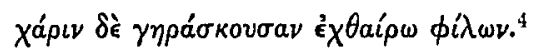

1Sup. 1108, 1112-3. 2Cyclops 432-4. 3Alc. 711, 338-9. 4H. F. 1223. 
"I hate a friendship which grous old"-i. e., a useless friendship.

Cf. a similar thot in Iph. Aul. (567-8): "A man of right feeling gains honor that nover grows old."

Cf. Supplices (1178); Cf. also Ion (700) where the chorus says of Creusa: "She is perishing of sorrow, entering as she is the period of hoary old age." In this play also the old pedagogue causes much merriment (1172) to the guests by his unusual assumption of other people's duties and by his eager

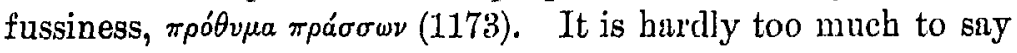
that this busybodiness would not have been tolerated in any one except in an old character. The very endurance on the part of the guests at the banquet of this old stranger's interference and assumption of duties for which there were regularly appointed servants points to a general attitude of complaisant endurance of a necessary encmbrance.

Cf. also in this connection (the utter uselessness and worthlessness of age) Demophron's reply to Iolaus when the latter had suggested that he be given to Eurysthens, and that the children go free: "What advantage shall accine to Eurystheus by the death of an old man? He wants these young Heraclide to die."

Under (b) (see p. 34) the pathetic scene at the close of the Bacche is apt. A feeling of utter helplessness comes over Cadmus when he thinks of his defenseless state now that Pentheus is dead-Pentheus, on whom he had leamed for support and defense against the taunts which were likely to be spoken at any time against lis age. Cl. lines 1304-25. Of these lines, however, note particularly 1:31:)-2:?.

Cf. here the pathetic scene in the Andromeda, where Andromeda, after having been rescued by Persens, is about to leave

1Notwithstanding this genelal belief that old age was a hated period, and that the work of the old was done, a belief which the old themselves shared in, they yet generally clung tenaciously to life (Alc. 669-70; Sup. 1109-10) on the principle which Euripides so often expresses, that life is sireet to all (Ores. 1523; Her. Fur. 92; Troad. 6323 ) and that we have only one life (Alc. 712), which must not be given up needlessly. This explains Pheres' obstinacy which Admetus could not or would not understand (Alc. 727).

2Heracl. 466-7. 
her home to become Perseus' bride. The old parents, realizing their helpless state, beg that both Perseus and Andromeda (or at least Andromeda) remain to care for them in their weak old age. Hartung, Vol. II., p. 357, describes the scene thus: "Parentes grandaevi, quamvis salute filiae guaderent, tamen se in limine vitae destitui, orbos relinqui neque habere qui curet et imbecillae senectuti consulat, aegre ferunt. Itaque pater rogat, ut ambo vel, si id fieri minus possit, filia apud parentes maneat: 'Alui, educavi: id facite gratum ut sit seni.'"

Note also the violence and contempt which Copreus in the Heraclide shows to old Iolans. (Heracl. 67-8). As Copreus says these words he knocks old Iolaus down. (70-1, 75-6.)

In the Andromache note the hauteur and insolence which Menelaus continually displays towards Peleus. (See p. 38.)

Note Orestes' (Electra 553-4) patronizing sneer at the old scrvant contained in his question to Electra: "Whose slave does this old relic chance to be?" And with this compare Ipl. Aul. (311), where Menelaus beats the faithtul old servant over the head. And compare also the scene in the Geneus where old CEneus tells of the abuse which he daily puts up with from his masters. Among other things he says that he has his head used as a scopus in the game of cottabos. (Hartung, Eurip. Rest., Vol. I., p. 156.)

This danger (to which the old were liable) of being maltreated explains in large measure the repeated reference to "childless" old age. They need defenders in age, and if the children whom the old had expected to be these defenders are taken away by a violent or untimely death, old age (always a wretched state) becomes most wretched. Herein lies the sting of Admetus' repudiation of his father and his exhortation to him to beget, the sooner the better, another son to care for his old age. (Alc. 662-4.)

References to this pitiable state of childless old age are especially frequent in the Supplices. Thruout this play this is a prominent thot. Cf. $13,35,83-5,170,782-86-97$, 800-15, $920 \mathrm{ff} ., 955 \mathrm{ff}$., 966-7, 1037, et pas.

I.ines $920-4$ may be taken as a good example of all these references: 


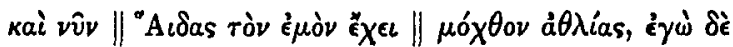

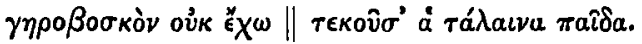

In the Andromache ${ }^{1}$ this thot is the first one in Peleus' mind as the body of Neoptolemus is brought on the stage (1174-8). It is repeated in $1205,1212,1216$, et pas. Very pathetic are lines $612-14$, where the old man is recounting to Menelaus his demerits and says :

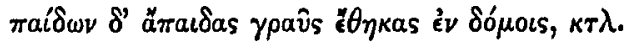

Cf. Ion 618-9: "I especially pity thy wife, 0 sire; for she is growing old without children!"

In the Hecuba, too, references to childlessness are very common. Polyxena bewails her mother's fate thus:

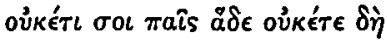

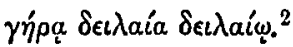

Hecuba's plaint finds its crux in this thot." Cf. also 514, 810, 821. Talthybius, in pitying Hecuba, says:

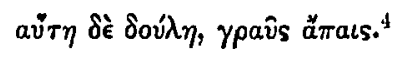

Cf. also the words of the servant girl (669). Cf. also Medea (1395-6), when Medea tells Jason that he will not know what true grief is till he gets old and finds out the sorrows of childless old age. Cf. also Medea's pathetic references to her impending childless old age (1032-3).

In the Troades note line 107; also lines 487-8, 599, 1185-6.

Cf. Frag. Alcmæon 77. This is spoken obviously with a feeling that childlessness in old age is an especially severe punishment for hauteur and insolence. Cf. Frag. Dictys 336, lines $3,4,6$.

In the Protesilaus, Acastus, father of Laodamia, is about to be deprived of his daughter. She is going down to voluntary death with Protesilaus. Acastus is greatly disturbed at the prospect that "relinquebatur grandaevo parenti orbitas" (Hartung, Eurip. Rest., Vol. I., p. 273), and he enters into an argument with his son-in-law trying to prevent the sacrifice.

Euripides, making use of this need of the old for protection, develops a very touching scene in the Iph. Aul. Iphigenia, pleading with her father for her life, calls up to him the pleas-

$$
\text { 1Cf. 307-8. 2Hec. 203-4. } \quad \text { 3Hec. } 440 . \quad \text { 4Hec. } 495 .
$$


ing fancies which he and she had indulged in during her childlood days as she used to sit npon his knees with her arms around his neck (1226) - fancies of her as a hajpy wile and of him as an old man, leeble and helpless, having no home but hers, and cherished and defended by her tender, loving calre. ${ }^{1}$

Résumí of $(a)$, Page 25.

This bodily infirmity of the old and its attendant weakness and loss of power', combined with an ardent desire to be young and strong, which we have shown to be a coustant and everrecurrent trait of the old in Euripides, is, as we said in the beginning (1. 25), one of the causes (we have made it the first (ause) of that other trait, "garrulity" which we discuss on pp. 52-60. The old, having lost their virility and force and desiring to corer up the lack of it by a bold appearance, were naturally led into much verhosity, hoping by bluster and braggadocio to impress others (and themselves) with their much prowess and forcefulness. They, howerer, deceived no one except themselves, and not always even themselves."

There is abundant evidence that others, as well as usually themselves, fully realized that "words" (๕̈ $\pi \epsilon a)$ were their chief stock in trade, and that forceful actions for them were impossible. The proof of this may be found at different places in the preceding discussion (pp. $24-35$ ). We repeat here only two especially significant lines from the Her. Fur., one, where old Amphitryon silys of himself:

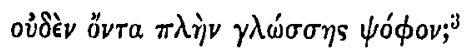

And the other, where the chortus silys of itself:

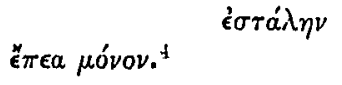

We will add, however, this other instance. In the Andromache Thruout the whole scene where Menelans and Pelens are on the stage the wealiness of the old in finding its expression in loquacity is everywhere prominent. Menelaus exhibits supreme contempt for Peleus, the caluse of which is that he is an

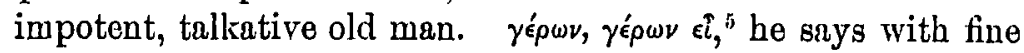
scorn; and he immediately adds (679): "Thy jabbering belps

\footnotetext{
IIph. Aul. 1226-32. 2Cf. Frag. Folus 25. (See p. 26, note 9.)

:H. F. 229.

+ H. F. 109-10. .And. 678.
} 
me more than holding thy tongue would." And he plainly and bluntly tells old Peleus that to "talk is all he can do." He shows his ntter indiflerence to this chatterbox, as he thinks, by coarsely telling him (689-90): "If you don't like what I say and do, you can wear your tongue out opposing it for all I care."

In this connection Cf. Frag. Melanipre 512:

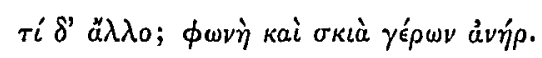

Te come now to the second subdivision, (b) of page 25 :

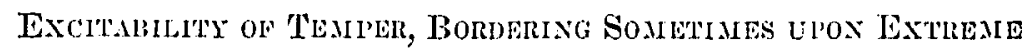
IRAsCIBILI'I'x.

This trait of character, excitability, naturally follows from bodily infimity and the wealkening of the power of sell-control. The old were rery susceptible to ontward environment, impatient of restraint, and fretful and peevish if circumstances did not shape themselves as they desired.

An excellent illustration of this trat of the old is fonnd in the Andromatcle. Old Pelens, in his atrgment with Menelaus, becomes so excited that: after he hats threntened to have him and Flermione kicked bodily from the house (7)18-10), he cannot (he is trembling so) untie the bands that bound Andromache's hands. He hats to call the boy, Molossus, to help him." In fact, Peleus' excitement and irascibility are so apparent to all that the chorus, noticing it, utters a gnome to the eflect that all old people are irascible and irritable:

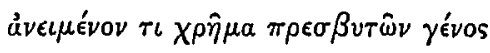

$$
\begin{aligned}
& \text { каi } \delta \text { vo }
\end{aligned}
$$

This excitement of old Peleus is evident f'rom his rery first appearance upon the stage, for when he first comes in he excitedly asks three questions, addressed to Menclaus, his servants, and then to Andromache (5-48-9), 555-6), without giving

1 And. 746.

2And. 717-8, 722-3. Cf. with this Iolaus in the Helacl. He cannot control himself sufficiently to perform the last sad rites for Macaria (564), and he is completely overcome and falls fainting to the ground when he bids Macaria good-by (602).

:Di: Verrall, Four Plays of Euripides, p. 34, speals of Peleus as "an honorable and noble man, but of violent temper' in his best days and now long past the age of self-control." *And. $727-8$. 
any of them time to answer. He impatiently chides his servant for leading him so slowly, and excitedly urges him to greater exertions. "It's no time for slowness," he says (551-2).

Cf. in this connection also the scene in the Heraclidæ where old Iolaus, excited and anxious about the war, asks three questions (383) in quick succession of Demophron, and even then does not give him time to answer till he has expressed his own opinion about the probability of the herald's fulfilling his threat, and also until after he has made two general observations based upon his own experience (381-8). Alcmene also is irascible and excitable. When she first appear's upon the stage (645), she becomes very excited, for fear that the servant has come to take away the Heraclidx. This excitement is increased $(660)$. Note the peculiar form of her question (661-2) when she finds out the real purpose of the messenger. So on thruout her stay upon the stage. Cr. her emotion (869-82, $941 \mathrm{tr}$.). And at the very end of the play, because of her excitement, she forgets within a few minutes her promise made in line 1023 to give Eurystheus' body to his friends; for in line 1050 she orders it thrown to the dogs. Old Iolaus faints away (602) from sheer excitement ${ }^{1}$ and in the Hecuba, Hecuba is so overcome at the thot of separation from Polyxena that she too faints (438).

Cf. also the excitability of the yoavs in the Helen. She too asks three questions of Menelaus (437-9), and does not wait for an answer. In her intense excitement at finding the stranger persistent she tries to shove Menelaus ofl by force (445-6).

In the Orestes, Tyndareus becomes very angry at Menelaus for his impiety in holding intercourse with the murderer, Orestes. He excitedly repudiates Menelaus' philosophic justification of his act by telling lim bluntly, "Shut up. I'll not put up with it." To this Menelaus replies:

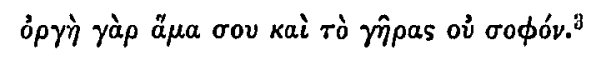

Again, the only eflect of Orestes' defense of himself (544$604)$, in which defense he boldly presents his side of the case

10ld Iolaus thruout is a good example of the excitability of age. It shows itself best possibly in his garrulity. For this phase of his nature see p. 57. 2Ores, $489 . \quad$ 30res. 490. 
and contradicts the conclusions of Tyndareus, is to anger ${ }^{1}$ the old man and to make him the more determined to bring about the death of Orestes. (See lines 607-9.) And the old man's whole attitude is so completely that of an irascible and irritable man that when he finally leaves the stage (629) Orestes says: "Begone! I may now, since thou art gone, address Menelaus without fear of boisterous interruptions" (630-1). These words are the more significant inasmuch as Orestes' attitude toward old Tyndareus was at first that of great respect and awe. ${ }^{2}$ The old fellow's harshness and irritability are alone responsible for the change.

Agave in the Baccha, not understanding because of her mental aberration why her desire to offer her son's head as a sacrifice to the god should be called by Cadmus $\pi \dot{\epsilon} v \theta 0 s$ ov $\mu \in \tau \rho \eta$ rov $^{\prime}$ (1244), attributes his attitude "to the natural moroseness of age."'; She says:

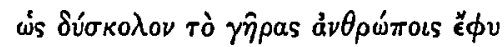

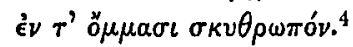

Thruout the Troades the excitement of the old is very marked. Hecuba is continually being led into strange acts and unseemly words. She falls upon the ground and refuses to be helped up ( $466 \mathrm{ff}$,), and speaks from her excitement words that ill become her. (See p. 23, "Additional Note.") The attitude of Andromache and Hecuba to Polyxena's fate is significant. Hecuba is excitable and distraught; Andromache is grieved, to be sure, yet calm and seeks by persuasion and argument to comfort her. Note her words to Hecuba at the beginuing of her speech. ${ }^{5}$

In the Alcestis, Pheres shows, thruont Admetus' speech (629-72), such decided symptoms of violent wrath that the chorus says in admonition $(674)$ :

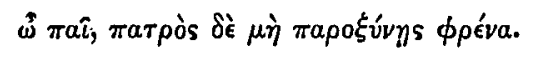

Another good example of the excitability of the old and of the loquacity which follows from it is in the Iph. Aul. The old man comes on the stage timidly, thru the half-opened door,

1Cf. the old man's anger and scorn when he first catches sight of Orestes (479). 2Cf. Ores. 548-9, $460 \mathrm{ff}$. 3Paley, note to line 1252.

†Bac. 1251-2. 5Tro. 635 . 
The Dramas of Euripides.

to tell Clytemnestra the real state of the case: that her husband is going to sacrifice her daughter to Artemis, not marry her to Achilles. He is so excited-he needs much assurance that he will not be overheard- $(862,863,866)$, that talkativeness gets full control of him. He apostrophizes $\tau u ́ x \eta$ and $\pi$ póvoca (\$64) and is so rerbose that Achilles, in despair of bringing him to composure, gives up the case as hopeless, and says: "I see that we shall have to wait some time before getting at what this man has to tell us; he has so much prefacing and pritying to distract his attention" ( $8\left(i_{5}\right)$.

Of a like nature is the scene in the Hecula, where old Talthybius comes in, sees Hecuba on the ground in a faint, and gets so excited that he forgets his mission, fills into a strain of philosophlic mediation of such a tenor as to be improper for an old min (see 1\%. 24. "Additional Note"), chalucteristically ${ }^{1}$ gets his grammar mixed up (omits the subject of $\kappa \epsilon \kappa r \hat{\eta} \sigma \theta \alpha \iota$ ),

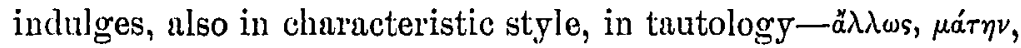
$\psi \epsilon v \delta \bar{\eta}$ (Hec. $488-500$ ), etc. And Hecuba ${ }^{2}$ in the contemplation of her woes grows now and again very excited, and busts out into a series of exclamations (Hec. 619)-23 et passim); or she shows lier passion by the interlocked order" of her words as when she sees her enemy and his chihdren before her and realizes that it all depends upon her whether she shall wieak rengeance upon him or not. Note also the old servant's excitement in the Electral when he recognizes Orestes (56i3 tl:), and the petulancy of the nurse in the Hippolytus (176 ti.). It even leads her into a little irreligion (see p. :, note !).

ISee p. 44.

"In the case of Hecuba, however, she exhibits at times a great degree of sell-possession. In her plea with Odysseus for the life of Polyxena (239 fi.), and with Agamemnon for help against Polymnestor ( $760 \mathrm{ff}$.$) , and in her interview with Polymnestor himself ( 968 \mathrm{ff}$.) she presents her claim in masterly manner, cunningly worliing now upon this and now upon that trait of character in these men. Her selfpossession and her arguments, however, are but that other trait of the old, "fertility in concocting schemes," manifesting itself in somewhat modified form. (For a discussion of this trait see p. $60 \mathrm{ff}$.) And yet even here she is not without evidence of latent excitement which may break out at any moment. Especially is this true in her plea before Odysseus for the life of Polyxena, for the first words of Odysseus in his reply are an exhortation to her to ponder the matter with calm and not with angry mind." (Hec. 299-300.) "Hec. 986-8. 
In the Phonix, Duripides makes the excitability of the old the crux of the drama. Amyntor, the old father of Phonix, is fanned into a flame of passion by his $\pi a \lambda \lambda a k i$, whose adulterous desires for the young Phonix had been repelled. The old man, "rehementer exacerbatus" and "recenti dolore furens," 1"efuses to listen to reason, but hastens, in spite of a calm and what should have been a convincing denial of his guilt by Phonix, to intlict upou his son severe punishment. At last, when all is over and Amyntor realizes what his old age has led him into, he cries out:

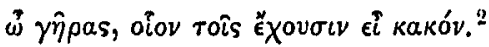

In the Gneus the excitability of the old GEneus, when he discorers that the stranger Diomedes is his grandson, is so great that he cannot endure it alone, but calls the chorus to share his joy. Aristophanes ridicules this excitement of old Eneus in Achar. 855 tf."

Cf. also the irascibility of old Phegeus in the Alcmieon in Psophide when he finds out the deception which Alcmieon has practiced npon him in relation to the necklace. Hartung (Eurip. Rest., Vol. 1., p. 192) sars of this scene: "Vehementissime Phegei ira exardescit:"

In the Dictys so great is the writh of the old man against his younger brother that the chorns thinks it necessary to reprimand him.*

In the Cyclops the excitability of the old is made to serve a lndicrous turn. This trat in Silenus is well shown in the scene between himself and Odyssens, when the latter mentions wine (139). At the mere mention of the wine the old fellow is all aglow, and cries out: "Hurrah! thou hast mentioned the finest thing." (1+1)). Cf. further his eagerness to know where the wine is (1+4). And when he sees the small skin in which Odysseus is carrying the wine, he is disgusted that it is so sinall an amount. "Why, that wouldn't fill my hollow tooth!" he says (146). Note his eagerness to get at the wine and his excitement when he gets a whiff of it," and then a taste." His reply to Odysseus' question as to whether it tasted good is

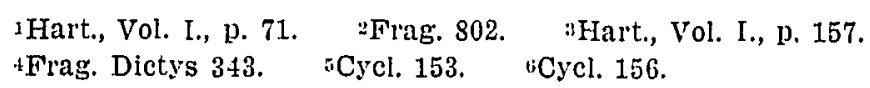


characteristic. "Yes; to the tips of my fingers and toes," he says. ${ }^{1}$ And when Odysseus suggests that he will give him money too, the old fellow excitedly says: " $O$, bother on the gold! The wine's enough!"'2

Repetition, Tautology, and Gramalatical Peculiarities.

This phase of the character of the old, excitability, manifests itself in the dramas of Euripides by repetition, tautology, and grammatical peculiarities in their speech.

\section{Repetition.}

Heracl. 48, 307, 449, 229, 225, 873; Hec. 59-61, 96, 155-77 (whole ode), 68!-90, 532-3, 710; Her. Fur. 1062, 1068, 1072, 1081, 1187, 1192; Bac. 1216-17; Hip. 355; Ion 735, 738; Tro. 239, 625; Phœn. 584; Elec. 487 ; Alc. 722.

In the Orestes old Tyndareus repeats in line 625 his threat against Menelaus, spoken first in line 587. T'atin (Etudes sur les Tragiques grec, p. 58, Vol. III.), after mentioning the fact that one of these lines has been thot by scholars "une indiscrète interpolation," says: "Peut-être y pourrait-on voir une imitation, assez dans le gont d'Euripide, et dans l'esprit de ce morcenn, des redites ordinaires à la colìre et naturelles à la vieillesse."

\section{T'autology.}

Heracl. 41, 196, 224, 305-6, 26-7, 320 ; Hec. 438, 439, 489-90, 499-500, 507, 619, 714-15, 837, 1055 ; Bac. 198, 1218; Hip. 356, 509; Ion 740-1, 792; Tro. 485-6, 496, 1242-8; Her. Fur. 1061, 1069 ; Phœn. SS, 98, 100, S44, 870, 1597-8; Elec. 490; Iph. Aul. 42, 115; Cyclops 6; Suppl. 191-2; Hel. 712-3.

Grammatical Peculiarities.

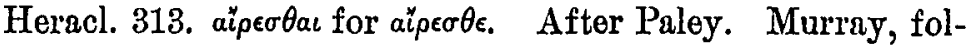
lowing Kirchboff, alters the text without MS. authority.

Heracl. 496. Starts with acc. and inf. and changes to another construction in the next line.

Heracl. 693. 'ंs $\mu \grave{\eta} \mu \epsilon v o \hat{v} \tau \tau$ (so-called pendent participle).

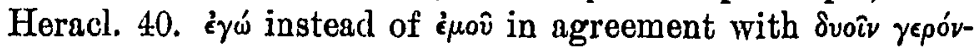
rouv (139).

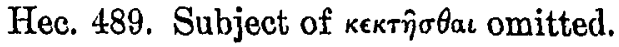

1Cycl. 159. $\quad$ 2Cycl. 161. 
Personal Characteristics of the Old.

Hec. 672-3. Mixing of personal and impersonal construction.

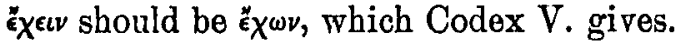

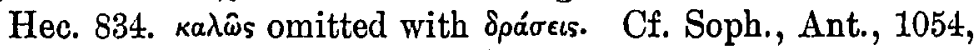

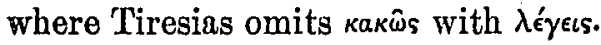

Hec. 887. $\Lambda \hat{\eta} \mu \nu o v$ should be $\Lambda \hat{\eta} \mu \nu o v$; and ả $\sigma \sigma \epsilon^{\prime} \omega \omega \nu, a ̈ \rho \sigma \epsilon \nu a s . ~ H e c$. 970-71.

Hec. 1214-15. Subject of '́ $\sigma \tau \eta^{\prime} \mu \eta \nu^{\prime}$ is very obscure.

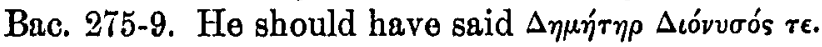

Bac. 1245. '̇ं $\epsilon \iota \rho \gamma a \sigma \mu \epsilon \dot{v} \omega v$ probably peculiar.

Bac. 1309. Here excitement and grief cause Cadmus to break out into direct address to Pentheus.

Ion. 319-21. $\pi \rho 0 \mu \hat{\eta} \tau \iota s$ for $\pi \rho \circ \mu \hat{\eta} \tau \iota v$.

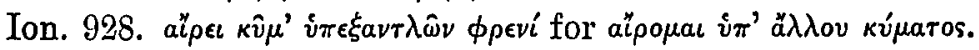
Text is Paley's.

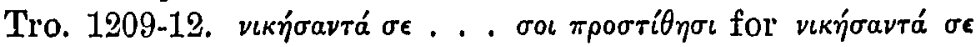
... $\sigma \tau \epsilon \phi \alpha \nu \hat{\omega}$.

Her. Fur. 191. Dat. for gen. case.

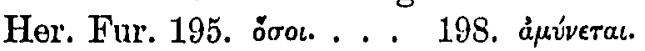

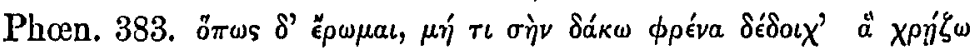

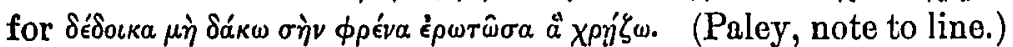

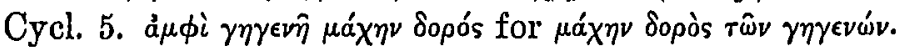

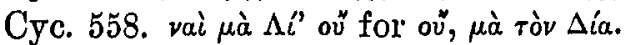

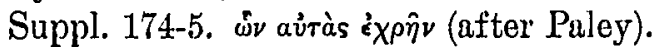

Suppl. 748. кєvai ought to be inserted before $\pi$ ó $\lambda \epsilon \iota s$.

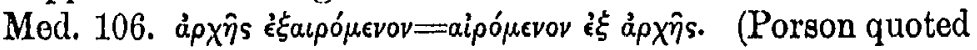
by Paley in note to line.)

The examples given under this topic, Repetition, Tautology, and Grammatical Peculiarities, are not intended to be exclusive, only directive.

We come now to the third subdivision, $(c)$ (p. 25).

A Conviction weat to Give Advice Was the Necessary Duty of Ord Age.

This trait of the old, this feeling ${ }^{1}$ that to give admonition was their preëminent prerogative, is much in evidence in Euripides. This prerogative of the old is also in large measure recognized by the younger characters, for it is not uncommon for the young to refer matters to the old for their advice and

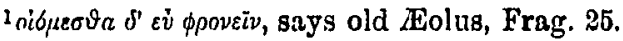


judgment.. Sometimes, however, headstrong youth repudiates this advice and takes gleeful joy in going counter to it. Generally, tho, the advice of the old is followed; but whether followed or not, it is always abundantly offered.

A good ex:mple of this admonitory tratit of the old is seen in the Phonissere. Iocasta, Tiresias, and Creon, the chief old characters of the drama, are fairly bubbling orer with advice. Jocasta is firmly convinced that hel age makes her preëminently fitted to be an adviser. Note her words to Eteocles (528-30). Tote also line 460. The chorus of young Phonicinn women also believe in this power of Jocasta to give good advice, for they say to her at the beginning of the conference between the brothers:

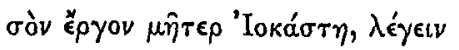

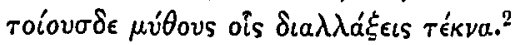

And the talks she makes to the boys (452-68, 528-\$5) bristle with advice. She glides from one admonition to another in quick succession. In fact, her propensity to indulge in exhortation makes her two speeches exceedingly verbose and garrulous. This, at any rate, is the effect of her' words npon Eteocles, for he says (592): "Do go away, mother, and free me from rour lengthy exhortations."

Creon also comes to give advice to Eteocles nyon the plan of the battle," and it is his advice that tmons the headstrong roung king, who is bent on rushing to battle instantly (712), to prudence and discretion. And when he finally does go to battle, le goes with a player to "caution" (782-3).

It was old Tiresias, so he tells ns, who tried to dissuade" the two boys from their wicked conduct towards their father (STS-9)).

In the Bacchie, Agave, recognizing that to give advice was the right of the old, tums to old Cadmus with these words: "My son must be advised, and you, father, are the one to do it." (1256- $\boldsymbol{\tau})$. Also in the earlicl portions of the play it is old Cadmus (and Tiresias; cf. especially 309.13) who under-

1 In the Melanippe, Helen, senex decrepitus, grandævus pater ZFoli, is summoned by the latter to ask his advice about the strange sight of cow and bull nursing and guarding children in the field. (Hartung, p. 117.) :Phœn. 444-5. 3Phœn. 706. 
takes to advise Penthens. At the conclusion of Tiresias' speech (266-327) Cadmus says:

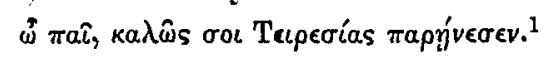

In the Ion it is the old pedagogue who acts as the mentor of Creusa at every point. In fact, he had heen summoned by her for this very purpose (728-9, 731-2). When she first hears of the sorrowful outcome (to herself) of the embassy of Delphi, and she is giving forth loud lamentations at her fate (702-7), the old man steps in with very timely advice (768-71). It is he also who, towards the end of his long and ganurulous speech (808-31, 836-56), first reminds her that her womnnly nature must assert itself and avenge these wrongs $(8+3-46)$. It is he, too, to whom Creusa turns in her distress for advice when she is at a loss as to the exact metus she should adopt to accomplish her ends. She salys to him (971):

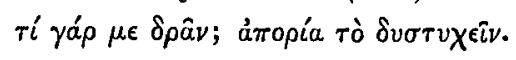

Another excellent example of the propensity of the old to give adrice, based upon opinions which their longel experience justifies them in forming," is seen in the Andromache. Old Peleus stops his quarreling with Menelaus long enough to say that he used to keep urging" Neoptolemus not to marry Hermione, and adds a word of adrice to suitors in general (61923): "I used to keep telling Neoptolemus," he says, "not to marry your daughter or, for that matter, any wicked woman. Ho, ye suitors," he adds, "keep this well in mind: Malury only the daughter of a good woman!"

In the Heraclidas, when the oracles all declared that a maiden must be sacrificed to Persephone (40S) in order to propitiate the gods, Demophron in great uncertainty goes to Tolans and asks his advice (420)2). And tho the old fellow proposes an jmpossible plan which Demoghron has to reject, yet the king feels such confidence in Iolaus' albility along this line that he asks him to try again (471-4).

Pheres in the Alcestis, angry as he is with Admetus, and

${ }^{1}$ Bac. 330. 2See pp. 49-50.

"In fact, the old man seemed to harp on this theme. At the end of the play (1279-82) he recurs to it and expands it with a good deal of vehemence. The old fellow's persistent nagging was probably so irritating that Neoptolemus out of sheer vexation did the contrary. 
sarcastic as he has just been, glides by the force of an old man's habit into a monitory strain (703-5).

In the Supplices it is Fthra's bold advice ( $307 \mathrm{ft}$.) that persuades her hesitating son to espouse the cause of the wretched women. Theseus responds to her advice thus:

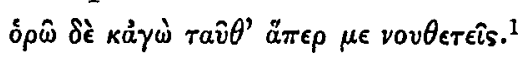

In the Troades, Hecuba declares that it was she who used continually to advise Helen during the course of the war to return to her husband and thus relieve the situation. Note the repetition of the words,

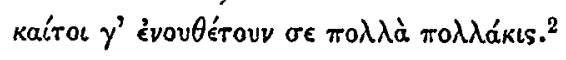

Hecuba's vehemence seemed, no doubt, to Helen the same kind of nagging as Peleus' did (see footnote 3, p. 47) to Neoptolemus. At any rate, it produced the same result.

In the Her. Fur., Megara appeals to old Amphitryon as to how to save themselves." She asks his judgment of her new plan, ${ }^{+}$and the old men of the chorus say to Amphitryon:

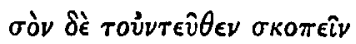

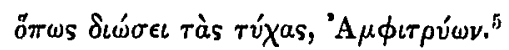

In the Cyclops, when Odysseus is trying to persuade Polyphemus to remain in the cave and get drunk (536-8), and when Cyclops wants to remain out for boisterous revel (537), he tur'ns to old Silenns, who has been standing by, and asks his advice (539). He tukes Silenus' advice and goes within. (Cf. 272-4.) Here Cyclops trusts Silenus in preference to the whole chorus of young Sityrs.

In the Electra, Orestes appeals to the old man for advice as to how he shall avenge his father's deatl. ${ }^{\circ}$ He does this again in line 612, and again in line 618 .

In the Orestes, Tyndareus, the old man, plays the customary rôle of censor, for he commands and threatens Menelaus to have nothing to do with Orestes (622-6). And further on in the play we are told that it was he who kept prompting the one who, at the meeting of the citizens, advocated the death sentence for Orestes and Electra (915-16).

1Sup. 337. 2Tro. 1015. 3H. F. $81 . \quad 4$ H. F. 278-9. $\quad$ бH. F. 314-5. Electra 599-600. 
In the Ipl. Aul. the old man plays the part of adviser and tries to console Agamemnon in his present distress (2S fí. et $p a s)$. It is the old man, too, who chides Menelaus in an admonitory strain. ${ }^{1}$

Note in the Gineus that the old fellow, as soon as lie gets a little over his excessive joy at finding that Diomedes is his grandson, lapses forthwith into a series of exhortatory gnomes on filial affection, etc. Fartung, in describing the scene, says (Eurip. Rest., Vol. I., p. 157) : "Deinde (i.e., postquam ad societatem laetitiae chor invitavit) multus fuit in laudando adhortandoque nepote."

In the Dictys we find old Dictys encomraging Danaë with bits of philosophic wisdom. Hartung spealss of him (Vol. I., p. 366) as one "qui, ut senex gravis et sapiens, philosophia pro medicina animi uti didicerit (didicit)." Of the whole tragedy he says: "Inerat . . . ei copia praeceptorum utilissimorum et sententiarum gravissimarum" (Vol. I., p. 372), due no doubt to the pervading presence of an old man.

Explanation of and a Conseguen't from the Beliff that it Was the Prerogative of the Odd to Give Advice To The Young.

This characteristic of the old, this belief that to give advice was their especial prerogative, was based upon the assumption that their longer life had given them a greater experience, and had therefore especially qualified them for the discharge of such a function.

In the Hippolytus the nurse gives as a reason for her moralizing (252) her experience and long life. Cf. also H. F. 801-6.

In the Heraclidre, Iolaus, after a piece of his philosophy, explains that he draws his maxims from his experience. ${ }^{2}$

In the Peleus, when Peleus and Neoptolemus are discussing the best means for punishing their enemies, old Peleus finds fault with Neoptolemus' suggestions and remarks upon the experience of the old."

1I. A. 303. Cf. in this connection the rôle of adviser to Phædra which the nurse plays thruout in the Hippolytus, 204-7, 214, 288 ff., 467, 473, etc. :Heracl. 5. iFrag. 622. 
In the Supplices, Thesens responds to Adrastus' confession that he had followed the advice of the young men, thus (161):

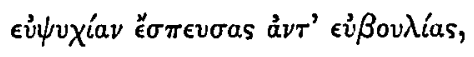

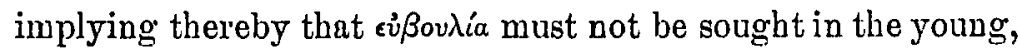
but is the prerogative of the old.

In Ethra's plea to her son (Sup. $297-381$ ) she displays in marked manner the shrewdness ${ }^{1}$ of the old and the clear insight of character which they had gained by long observation, for she skillfully plays upon the chord which is most sensitive in the young, that of pride and vanity. She warus Thesens (and this is the point she elaborates in one way or another) to be careful lest he should gain a reputation for being valiant at a boar hunt, but cowardly when reall deeds of valor are demanded $(: 314-17)$.

Note also, in this connection, the admonitory right of the old, the Fragments, Bellerophontes 29:3, Melanippe vincta 511.

One consequent of the assumption that the old had in greater experience was the feeling that gnomes and sententions remarks" were especially opportune when spoken by them. There are thirty-fire old people to ninety-nine young chancters" in the dramas (phus those in the haments).

1Thus it is the old who because of their greater experience ale put forward to explain away the verbiage of mythology (Bac. 295-7, Tro. $969 \mathrm{fr}$., etc.), tho clinging tenaciously to religion.

"Euripides was particularly fond of sententious remarks. For this he was perhaps equally praised and blamed by the ancients. Aristotle thinks him the master of rwouloria (Hofinger: Euripides und seine Sentenzen, p. 8), and Aristophanes (Ran. 949) complains that with Euripides women and slaves, old follis and maids lnow how to philosophize. With this cf. also Plutarch de Rect. Rat. Aud. C. 13: pínjato $\delta$ àv ris. . .

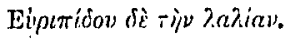

:The following is the number of the sententious remarks found in each play, together with the number of the characters, old and young. The choruses are omitted, since their function was chiefly admonitory, sententious, etc. The gods are also left out. Wise sayings would natinally become them:

\begin{tabular}{|c|c|c|c|c|c|}
\hline Bac. & $\ldots \ldots \ldots \ldots \ldots \ldots$ & $\begin{array}{c}\text { Old Ptople. } \\
2\end{array}$ & $\begin{array}{c}\text { Younz Peojic. } \\
5\end{array}$ & $\begin{array}{c}\text { Gnomes by } \\
\text { Young I rophe. } \\
5\end{array}$ & $\begin{array}{r}\text { Ginomes hy } \\
\text { Old l'eople. } \\
4\end{array}$ \\
\hline Hec. & $\ldots \ldots \ldots \ldots$ & 3 & 5 & 6 & 11 \\
\hline Elec. & $\ldots \ldots \ldots \ldots \ldots$ & 1 & 5 & 25 & b \\
\hline Ores. & $\ldots \ldots \ldots \ldots$ & 2 & 7 & 22 & 4 \\
\hline
\end{tabular}


These thirty-five old people speak one hundred and forty-four gnomes to two hundred and ninety-two spoken by the ninetynine younger characters-that is, twenty-six per cent of the characters speak thirty-three per cent of the sententious re. marks.

In the expression of these gnomes and sententious remarks by the old we find that Euripides more or less closely observed the following lule:

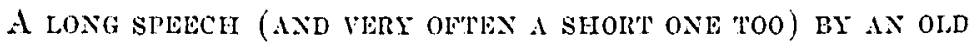

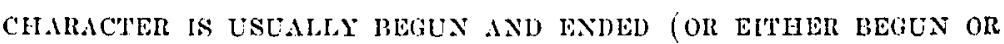

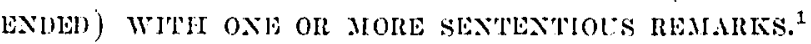

In the Phon. Jocista begins her speech (452-68), and both begins and ends speech beginning with line 52s with a sententious remark. The old pedangogue ends his long colloguy

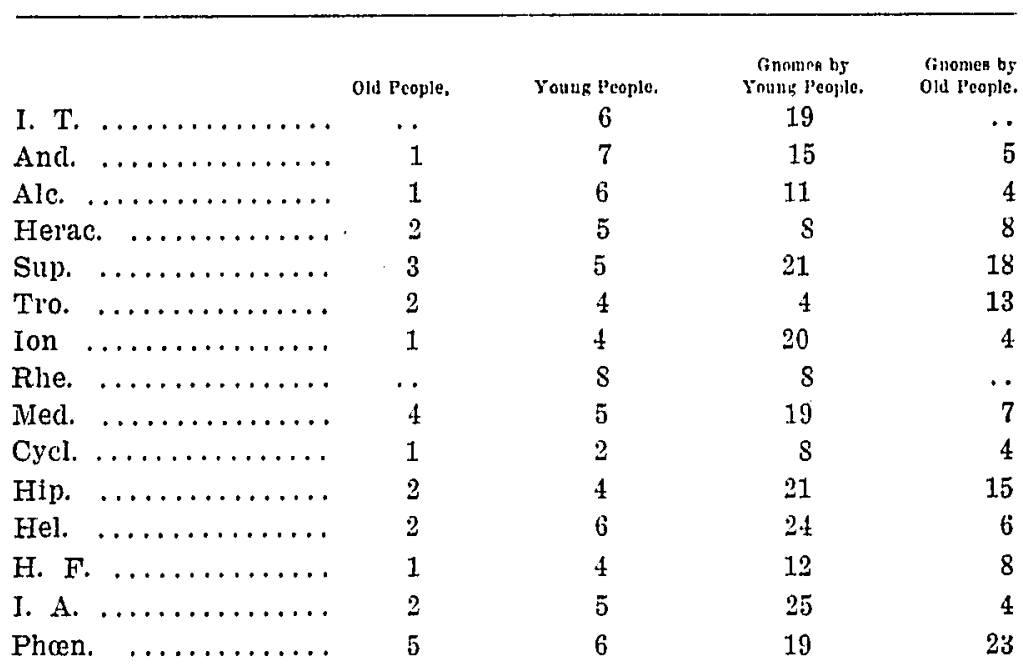

From this table it is seen that in only five plays, Ores, Ion, Med., Hel., and I. A., is the percentage between the number of young characters and their gnomes greater than that between the number of old characters and their gnomes.

ISince formulating this statement, Hofinger's work, Euripides und seine Sentenzen, has come into my hands. His answel to the question, "Wo bringt Euripides seine Sentenzen an?" coincides so closely with my statement that literary dependence would seem implied. $\mathrm{He}$ does not, however, notice the predilection of the old for gnomes. See his worli, pp. 11 and 12 . 
upon the walls with Antigone with a gnome (200-1), as also Tiresias his long speech (930-59). So also Creon (1310-21).

Cf. also Bac. 266-7, 1326-7; Ion 854-6, 1045-7; Hec. 294-5, 628-9, 844-5, 1187-94; And. 639-41, 693-703, 724-6; Heracl. 1-5, 181-3, 297-9, 327-8, 458-60 ; Alc. 627-8, 703-5; Hel. 711-15, 731-3, 744-57 (one long reflection); Sup. 162, 191-2, 331, 734-6 (old Iphis is on the stage only long enough to speak 56 lines, yet 30 of these are devoted to philosophic reflections of the most pronounced type; cf. 1080-1114); Tro. 466, 509-10, 1203-6; H. F. 57.9; Elec. 605-7; Hip. 480-1.

\section{GARRULTTY.}

We now come to that trait itself of the old, garrulity, which is, as we have said (p. 25), the resultant of these other traits, "feebleness of body," "irascibility of mind," and "admonitions to the young," which we have been discussing. Much of (a) (pp. 25-39), (b) (pp. 39-45), and (c) (pp. 4552) could with propriety be placed here, and must be interpreted as being illustrative of the garrulous trait of the old. We confine this particular topic, howerer, to a discussion of some of the most noteworthy cases of the garrulity and loquacity of the old characters.

An excellent example of this trait of the old, garrulity, is the speech of the old man in the Ion (808-31; 836-56). His tongue fairly runs away with him, and his "imagination thruout the scene travels far beyond the previous brief statement of fact by the chorus." This brief statement of fact by the chorus was:

First, that Apollo has given to Xuthus as son (774) him whom he should chance to meet as he left the temple (787).

\footnotetext{
1Lallier, De la Condition de la Femme, p. 210, tho speaking on an entirely different line from our present one, cites from Menander (ex. inc. fab. fr. 17) an interesting passage, which he thus gives: "Quel ennui de tomber au milieu d'une repas de famille! Le pèro prend la coup et commence la conversation . . .; ensulte c'est la mère, puis la grand'mère qui radote, puis un vieillard à la voix cassée, le père de la grand'mère, que la vieille appelle 'mon bon ami;' lui cependant fait à tout le monde de petits signes de tête."

2Bayfield, Ion, note to line 830 .
} 
Second, that this had happened to be the young attendant of the temple, whom Xuthus had subsequently named Ion (795802 ).

With this as a basis, the old man, led on by his excitement and by his innate talkativeness, after a long preface ( 808 814 ), builds up quite a circumstantial tale of cause and sequence. According to the old fellow's imagination Xuthus had secretly proposed after his marriage with Creusa to beget children by another woman (815-16); that he then gave his child to Apollo (\$20) to rear, and when the child had had time to grow to manhood (823) he persuades Creusa to accompany him to Delpli, ostensibly to ask relief from continued childlessness (\$24), but in reality (cunning fox that he was, 826) to get his own son and to lead him back to Athens (82S) and then to crown him king (836); that the accidental meeting and the accidental name were in fact no accidents at all, but well-matured and cunning plans (826, 830-1). "It is remarkable that we are not told by what name Ion was known before meeting his fathel." 1 The old man then launches out into a more or less detailed statement of what Xuthus ought to have done and what Creusa must do, getting in, in passing, several gnomes and sententious remarks-the whole representing a remarkable instance of the garrulity of the old. ${ }^{2}$ The above may be more graphically expressed thus:

What the old fellow knew was true:

(a) Loxias promised a son to Xuthus (774).

(b) The son was now a young man (780), and was he whom Xuthus should meet as he went out from the temple (787-8).

(c) The son had turned out to be the temple attendant (795). What he thot was true:

(a) Premeditated insult and exile for himself and Creusa.

IBayfield, Ion, note to line 830 .

2With this compare the similar scene in the Orestes (615 ff.), where old Tyndareus, confessing that he is angry (608), is led by his frenzied imagination to enumerate the many things which Electra had whispered into the ear of Orestes, urging him to kill his motherthe dreams, the lecherous couch, etc. Tho it all may be true, and probably was true (Cf. Ores. 1236; Elec. 967), the old man has had no opportunity to find out whether it is true or not. He assumes it and garrulously states it as fact. 
(b) Secret amours of Xuthus after his marriage with Creusa when he saw that she was sterile (816-18).

(c) These amours were with slares (819).

(d) Child sent to Delphi to be reared (820).

(e) Child renred as devotee of Apollo, so as to escape detection (821-2).

(f) An embassy to Delphi with crafty intent (823-4).

(g) A false name to covel a false act (830-1).

(7) This slave's son to be set up as lord of the realms.

(i) Details of the action Xuthus should have followed (839$42)$.

(j) Exhortation to revenge ( 843 fi:.).

(k) Sententious remark ( $848 \mathrm{fi}$.).

(l) Readiness to help ( 850 ff.).

(m) Sententious remark (S5̆4).

Another good example of the garrulity of the old is seen in the Phœuiswe, where Jocasta undertakes to bring about a reconciliation between her two sons (452-68, 528-85). Beginning with a gnome (452-3) to the eflect that "haste and justice are in no sense allied," she passes to a long haumgue upon the need of those who seek reconciliation to look one another in the eye (461-4). Having thus cleared the deck for action, so to speak, she proceeds, after her two sons have spoken, to a refutation of their claims. She begins with a declaration that age is eminently fitted to give advice (528-9), then passes to an excoriation of $\phi i \lambda o \tau i \mu i a$ (531 fit.), thence to a very wordy

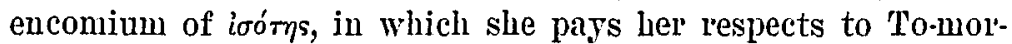
row, Day, and Night; thence to an analysis of ropavís (549 fl.). and to a consideration of the transient nature of wealth.

This to Eteocles and a like, tho not quite so long a rambling, to Polyneices. In it all, however, she gives not one pertinent suggestion as to the hou the two boys should become reconciled. Her excessive garrulity has clouded the issue, and her words have little or no real significance. It is no wonder that Eteocles, bewildered by his mother's loquacity, says: "Mother, this is no place for lengthy speeches. The time is flying by." (588-9.)

This tendency of Jocasta to untimely talk and discussion is also well seen in the long stichomytly between herself and 
Polyneices beginning with line 38S. This dialogue Jocasta begins by setting forth first a philosophical question for discussion: What is deprivation of country?

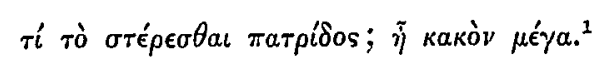

It would seem that here at least, when all parties are in such unpleasant straits, she would repress her loquacious tendency and confine herself to the particular needs of the occasion and indulge in no excessire questions or remarks. Not so, however, for she leads the talk into many odd and peculiar channels.

Also at the end of this same play, when Euripides introduces Edjpus for dramatic effect, ${ }^{2}$ he extends the scene beyond all necessary limits by "tacking on to no purpose a vordly ode."

In the long speech of Tiresias (Bac. 266-327) we have another good example of the prolixity of the old. In a wordy preamble the old seer delres lengthily into mythology (302, $275 \mathrm{ff} ., 286 \mathrm{ff}$.), into etymology (276, 293-5), into psychology (303-4), into prophesyings (306-9), into argument by analogy (319-21). In the midst of all this extra talk he happens to get in (309-13) the real point, exhortation to Pentheus to adopt a different attitude toward this new divinity.

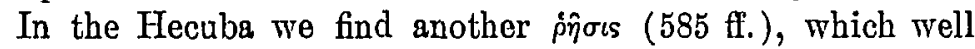
displays the loquacity of the old. Hecuba has just been told of Polyxena's death. Her daughter is still lying on the mound where she has been sacrificed, with fresh gaping wounds which need attention, and a lifeless body which should be washed and anointed for burial. We should suppose that a mother under such circumstances would rusli instantly to these duties first and moralize and talk afterwards. It is not so, however, with Hecuba. She indulges in many lamentations upon the succession of sorrows with which she is engulfed (585-90), then she reflects upon the ever constant nature of man (592 ff.). This opens an interesting field of investigation; and forgetting, at least temporarily, all about her unburied daughter, she

IPhœn. 388. 2See Dramatic Characteristics, p. 90.

Aristoph. in his $t \pi \delta \theta \varepsilon \sigma s$ says:

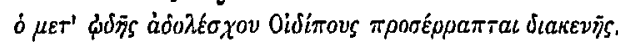

It is "to no purpose" if not to develop this trait of loquacity in the old. 
launches ont into a discussion of the cause of this. Of a truth these are "ill-timed reflections." Hecuba herself realizes all this, for she says:

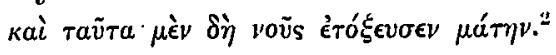

And yet, notwithstanding hel: own realization that these reflections are "shot out in vain," she recurs within two lines to further ill-timed observations about the lawlessness of armies and navies ( $606 \mathrm{fr}$.). In all this Hecuba is yielding primarily to the spirit of garrulity inherent in the old. They must indulge this propensity even when they themselves realize, as in this case (603), that actions, not words, are imperative. ${ }^{3}$ And even after she hats concluded (618) her commands to the àpxaía $\lambda a ́$ rpts, she bursts out into a series of exclamations and sententious remarks which serve more fully to bring out her excitable and garrulous nature.

Hecuba displays this trait of garrulity thruout. Her appeal to Agamemnon (786-845) is excessively and unnecessarily long. Lines 812-32 could easily be omitted. They add nothing to, but rather detract, from the force of her plea. For example, moralizing abont $\pi \epsilon \theta_{\omega}$ ( $813 \mathrm{ff}$. ) is inane. Lines $821-23$ merely repeat $808-11$; her appeal to venereal pleasures (826-32) even she herself feels is wide of the mark (\$24-5). Even if line 833

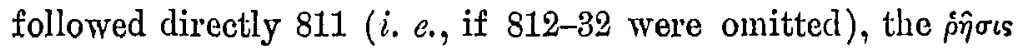
would still be long and verbose.

For the impression old Pelens in the Andromache, in his excitement and flur'ry, makes upon his fellow-actors and their characterization of him see page 38 .

In the Helen the messenger, tho an unimportant character and having but little opportunity to speak, takes advantage of every opportunity he has to display his garrulity. For example: He is commissioned by Menelaus (737) to carry a message to his companions on the shore. The old fellow, instead of obeying instantly, pauses to give vent to a long and rambling meditation ( $744 \mathrm{ff}$.) on the vanity of oracles, the remissness of Calchas and Helenus, the proper subjects for

1 Decharme, p. $40 . \quad$ 2Hec. 603.

${ }^{3}$ Decharme (p. 41), observing this ill-timed pijous of Hecuba's, assigns the reason for it to an intention on the part of the poet "to please an audience that reasons and is fond of subtleties." 
prayer, and ends by giving his concept of success in life. Also prior to this the old fellow had displayed his tendency to talk. When he hear's of Helen's identity (709-10), he breaks out into a long speech (711-38, supposed to be one of jubilation) in which moralizings ${ }^{1}$ are interspersed with more or less inapt references to the long past.

Old Tolaus in the Heraclidie gives on every hand evidences of the garrulity which is inherent in the old. He is excessively verbose, and cammot speak, it seems, without letting his talkativeness run away with him. An example of this trait is seen in his speech of thanksgiving to Demophron when the latter has announced his intention of giving the Heraclids an asylum. The old man's joy knows no bounds. He bursts forth into a fulsome eulogy (with pointed reference to Demophron) of glorious birth and its sulficiency in times of stress $(297-303)$. With great excitement he then verbosely calls upon the two parties to the transaction to shake hands (307-9). He follows this with a long exhortation to the children, if they ever get back to their country, to enter into an everlasting treaty of peace with Athens (310). And then, in the very excess of joy and excitement, he declares in grandiose style (320-36) his fixed intention not only of singing Demophron's praises in this world, but of sprealding abroad in the realms of death the glorious tidings of Demophron's magnanimity:"

Another good example of Iolaus' garlulity is seen in his ṕñ $\iota s$ beginning with 427 . Demophron had asked his opinion (420) as to low the decree of the gods that a maiden must die could be met. Instend of answering the question tersely and concisely as the exigencies of the time demand-the enemy is already encmuping on the border's of the land (389) spying out the best rond by which to make the incursion (395) - he bursts out into figurative language and compares lis plight to shipwrecked mariners who are dashed onto a reet and almost saved, only to he carried again far out to sea and lost (427-38). This comprisison, pretty and apt enough as it is

JRassow says of the old man: Philosophandi est amantissimus, p. 15, de Euripideorum nuntiorum narrationibus.

"Paley is quite right when he speaks (note to line 429) of Iolaus as being "profuse in his thanks." 
but inopportune beciuse of the stress of circumstances, does not bring even with its end the advice Demophron wints. A long harangue follows, interweaving regret and unfulfilled hopes (433), praise of the king, protestations of eternal gratitude to him (438), with lamentations over the fate of the bors (439), and of the good dame Alemene (4t7) and of himself (449). Finally, after all this preamble, he bethinks him of Demophron's request and at last comes to the point.

Note .Ethra's rambling preface to her plea to her son (Sup. 297-300). Note further that in Adrastus' funeral oration, lines $907-8$ are a tautology on liue 902 .

In the Troades note Hecuba's response ( $686 \mathrm{fl}$.) to Andromache's consolatory pî and to the point, she prefaces what she has to say with a long (686.93) description of a picture representing a storm at sea which she had once seen and hatd described to her (687), and this ton in spite of the fact that she tells us her grief has taken awa her power of speech (69-5) ! Hecular's reply (9681082 ) is one-filth as long again as Helen's defense of herself (914-65), itself verbose enough. It contains eleven more lines than Helen's speech-that is, Hecula, who is taking up each point of Helen's defense, elaborates upon them more lengthily than Helen had done upon the original points.

In the Her. Fur. old Amphitryon characterizes himself as an empty sound, and he lives np to this self-chatracterization in excellent wise. Among other instances of this we may note the following: When about to die, as he thinks, he wants to bid the chorus good-by. Instend of doing this directly in a few well-chosen words, he takes occasion to chide Zens on his apparent neglect of the Heraclide (498-500); he then philosophizes on the brevity of life, the need of enjoyment, the change of fortune, his own sad state (503-12). At last he gets to the good-by (512-13).

In the Cyclops, silenus is the loquacious old fellow we should expect to find. He is typical in this as in every other respect. His fluency of speech is well illustrated in his wonderful oath $(2(62-8), 2$ in his long meditation on the delights of wine (16:3-

1Her. Fur. 228-9. 2See Religious Trait, p. 9. 
$7 t$ ), in his fertile imagination of what Odyssens had said about the Cyclops (232-40), etc.

In the Electria, tho the old servant comes in all puffing and blowing ( $4 S T$ ) and tired out, he has breath enough to enumerate with much fulluess all the supplies he has brought-a kid, myrtle, chcese, wine (4)4-9). And alter a short bleak of five lines he describes with great accuracy of detail his joumey to the tomb of Agamemnon (508-23).

In the Iph. Aul. the opening lines (1-48), which some hare thot spurious because of their content, are, in the light of the attributes of the old, nitmal and proper. For if we remem. ber that one of the chicf traits of the old people of Euripides is their garmulity, love of meditation, etc., we find little dil'ficulty in understanding "the rambling conversation of the old man and Agamemnon on the time of night (6-11), the disadvan tages ol "auk (16-26), the necessity of contentment" (30-3), etc. This "rambling conversation," Which has given some commentators much trouble. makes the scene very chatracteristic of Enripides and gives the exact setting we should expect to find in any scenes of oul poet's dramas in which an old person is one of the lealding chanacters.

In the Hippolytus the old numse of Phredra is a talkative, philosophizing body. Note her excessive moralizings at the bedside of her sick mistress" (117-98) ; note also the verbosity, due to her excitement, of lines 35:3-61, etc.

1 England, Introduction to play, p. xxiii.

-Paley says (note to line 177) these molalizings "are out of time and place." Harry (Introduction to Hippolytus, p. xxxii.) says "they are not al together suited to the character of a tpopbs." He says further that Euripides "fails to characterize shalply enough." Should we not rather say that, in representing this old person as a garrulous and moralizing character, he was characterizing very sharply? Especially does this prove true when we compare with the rpoós in the Hip. the Tpopos in the Medea. This latter is the same kind of garrulous and reflective person. In the prologue of 48 lines, four of which may be spurious, she indulges in not less than three distinct bits of philosophic reflections $(14-15 ; 34-35 ; 48)$. Moreover, in addition to this, she gives with much repetition the results of her experience and obser-

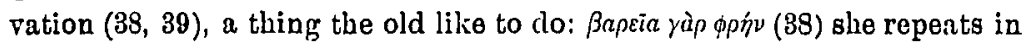

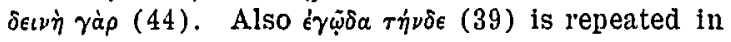


A significant passage along this line-love of talk in the senile character-occurs in the Medea where the old pedagogue tells us that the old men of the city habitually frequent the parks, play games, and grossip. It was from such a gossiping band of maגaitaroc that he first heard of the impending edict of exile against Medea and her children. ${ }^{1}$

We may note here also old CEneus, in the play of that name. Tho declaring very vehemently that he has not the time to talk to the strangers, Diomedes and sthenelus, yet when once started, excusing himself: for his loquacity by the reflection,

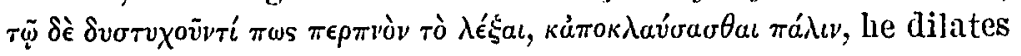
at great length upon the many evils he daily endures. Note also that the old man, under the excitement of the discovery of the identity of his grandson, layses into a lengthy laudatio et adhortatio nepotis."

\section{FERTILITY IN IDEVISING SCHEMES.}

The next trait of the old which we may notice is their wonderful fertility in devising ways and means to meet any emergency which arises. What Euripides says of women,

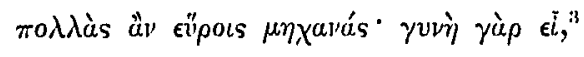

he undonbtedly thot a trait also of the old; for everywheres when perplexity arises an old character, if any one is at hand, is the one who suggests (their advice is generally asked, Jlec. 598 ) a plan for the solution of the difficulty. This is very natural, and lollows necessarily from that trait which we have

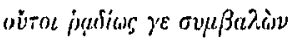

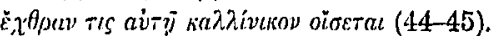

Moreover she is everywhere a garrulous moralizer. Cf. $119-30 ; 190$ 200. Her loquacity is even recognized by the old pedagogue himself; for he sharply chides her for standing outside, near the gate, talking to nerself (50-51).

1Med. 67-69. 2Eurip. Rest., Hartung, Vol. I., p. 157.

:And. 85. Cf. Hip. 4S0-1. Also cf. Frag. Danaë 323.

Exceptions are very few. In the Helen it is Helen who proposes the scheme (1049 ff.) which is to save them from the clutches of Theoclymenus. Menelaus (note that he was a young man; had he been an old man he would have been more successful) had tried in vain to think of something that would do $(1039-40 ; 1043-4)$. In the Orestes, Pylades proposes the scheme to humiliate Menelaus (1098 ff.), which Electra, a woman, enlarges and perfects (1189 ff.). 
already discussed, the feeling that the old were especially able to give advice (pp. 45-52); for the advice which the old gave would naturally (and we find it so) be joined with suggestions as to how to act in the matter in hand.

The old too felt this power of theirs, this ability to devise ways and means to meet any emergency, for they are everywhere found expressing supreme confidence in their mental acumen and quick-wittedness. In the Ion the old man says, as he comes hobbling in (742):

isoú

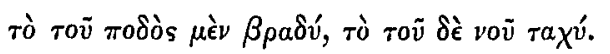

In the Iph. Aul. the old man there has the same opinion of himself. (See page 31 for Greey. I. A. 4-5.) In the Medea the old pedagogtue surcastically vaunts his knowledge and shrewdness over the nurse's. He says to her':

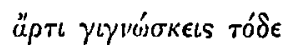

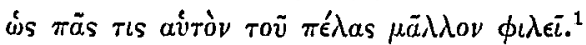

Also in the Iph. Aul, we are told that old Tyndarens, because of his shrewdness of mind ${ }^{2}\left(\pi v \kappa v \tilde{\eta} \phi \rho \in v^{\prime}\right)$, got the better of the suitors of Helen (55-6!)). And the $\pi \rho \epsilon \in \beta v$ s in this play easily sees thru the trick of Agamemnon in summoning Iphigenia and draws from him a confession of his real intentions (133). ${ }^{3}$

Old Amphitryon in the H. F., tho Megara is all cast down and discouraged, refuses to give up hope. He says to her (91): $\phi i \lambda \tilde{\omega}$ ràs $\dot{e} \lambda \pi i \delta a$ s. He fecls his own power to plan, and consoles

1Med. 85-6. 2Cf. ZEoleus, Frag. 25, where old FEolus says:

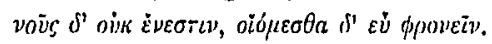

IIn strange contrast with the keenness of intellect and shrewdness everywhere displayed by the old is the obtuseness of the old man in the Ion. He does not understand what Creusa is getting at, even tho she had said she had married Apollo against her will (941), until she bluntly says: "I am a mother" (947). Cf. also the nurse in the Hip., who cannot divine what Phædra means. Note also Iolaus in the Heracl. He cannot remember where he had met and seen the Aegánuv before (638). This is the more noteworthy inasmuch as line 45 leads us to suppose that Hyllus has not been long away. These cases of mental inertness on the part of the old serve to bring out their failing powers and intensify the pathos of the scene. (See Dramatic Traits, 85ff.) Cf. also here the $\pi \rho \dot{\varepsilon} \sigma \beta u_{S}$ in the Elec. His schemes seem so frivolous to Electra that she finds in them the corroboration of her longfelt fears that the old man was losing his mind (568). 
himself with the thot that "ill luck, like tempests, cannot continue always" (101-3).

We find a similat scene in the Troades showing the resilience of the old because of their confidence in themselves and in their ability to plan and scheme. Andromache is in despair and wants to die. She has not even one bope left (681-3). Old Hecuba, however. hopeful to the last, devises a scheme and urges a diplomatic plan-obedience to her new husband with the end in view of saving Astyanax. who some day may re. build Troy ( $(697-705)$.

The old are seldom canght off their guard. Old Amphitryon, again in the F. F., is ready with a plausible excuse when lycus asks him to go in and bring ont Megara and her children. His crafty purpose is of course, to get Lyeus to go in himself and thus meet the wating Hercules (720)-1; cf. also $704-(6,707$ 11).

In the Electrat it is the old man who, in the dialogne between himself and Electra, suggests all the ways whereby a recognition of Orestes might be effected: First, compraring the lock of hair (520); second, comparing the stranger's footprints with Electra's (5:32-4); third, a woven gallment (539)-40). The insulficiency of these plans. due to the excitement of the old man, in no wise affects the point we are making. 'They bring out, whether ayt or not, the wonderful fertility of the old in suggesting plans, a lertility which is recognized even in this old maln; for in spite of his crazy notions (5)(iS) his advice is asked the first thing when Orestes and Electra came to a serious consideration of their future actions (5)s; (i1s). And except when Electra suggests the way to accomplish the death of Clytemnestra (6it. If.) it is the old man who suggests, after he once comes non the stage, all the schemes in the playthe way to take vengeance on Agristhns, etc. (619).

In the Ion it is the old mem who suggests to crensal various

1 Hartung, Eurip. Rest., Vol. II., p. 309, calls attention to the fact that in the Chcphori of Aschylus Electra is taken in by wild schemes for identification and remarks: "Ad senem . . . a virgine credulitatem transtulit Euripides ideo, illum, "ex vanis rebus spem captare" minus, quam filiam Agamemnonis, dedecere arbitians." 
wild schemes for vengeance-burn the temple (974), kill Xuthus (976), kill Ion (978), etc.

In the Hippolytus the ability of the nurse to scheme and plan is nothing short of marvelous. Her persistency too is noteworthy. Tho almost exhausted with her former efforts to find out Phredra's secret and tho apparently ready to give up discouragerl (28t), yet sle shows the inexhaustible fertility of her time of life (and sex) in devising ways and means for accomplishing her purpose. She returns to the attack undaunted (285). And when at last she does discover her mistress' secret, tho at first aghast at the disclosure of Phadrals incestuous passion (4:33-4; (ff. also $35 \%$ ff.), she som recovers her poise and cleverly evolves a sophistic argument justifying Pliedra's yielding to ber love. (Cf. the whole pino s from 439 on.) This plan failing (50:3), she is ready with another plan (510 ff.); and even after this too has dismally failed, so that the nurse herself acknowledges that it has failed (698-9), she will not give np, but wants to propose another scheme (705). She is jrerented from doing so mly becanse Phaedrat herself tersely dismisses her with the injunction to attend to her own business (70)-9) .

In the Bacche the shrewdness of the old in suggesting schemes is well shown. It was at Cadmus' instigation, so his daughter sald, that semele had referred her son's parentage to Kens so as to escape the shame of haldoty (28-30). This was probably true, for Cadmus' religious fervor townd Dionysus is not, we susplect, wholly disinterested. There seems to be a cumning purpose back of it (181-8). We catch a further glimpse of this purpose in his exhortation to Penthens to honor Dionysus even if he be not a god, so that their race may have the glory of sccming to have begotten a god (8:3is-(i). On the other hand this suggestion of Cadmus' does not indicate (eren tho he is not wholly disinterested in his service) in Cadmus himself any lack of faitl. In fact, he exhibits as an old man the usual strong traces of religious piety and reverence. (See Religions Trait, pp. 2-4.)

Hecuba in the Hecuba also displays in a marked degree this trait of the old to devise ways and means to meet an emergency. Even in her distress in the impending loss of her danghter she 
is able to suggest an admirable plan for saving Polyxena (287 fi.). Also for the hesitating and weak Agamemnon she has a plan of action ready which meets well the conditions ( $869 \mathrm{ff}$.).

A somewhat amusing illustration of this trait occurs in 970-, 974-5, where Hecuba attributes her inability or unwillingness to meet Polymnestor's gaze, to shame at her present distressing lot and to her strict observance of the laws of modesty. This is really too much atter the bold and immodest conversation which she lias just had with Agamemnon ( $825 \mathrm{fl}$.) in which, with great laxity of speech, she refers to Cypris and her pleasures. In fact, Hecuba's effrontery on this occasion suggests to us Admetus' exclamation:

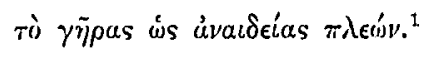

Old Iolaus in the Heraclide is also filled with schemes and plans (see Admonitory Trait, p. 4i). Tho these schemes do not always fit, as is also the case with the old man in the Electra (p. 62), yet the old man is seldom without some plan which (he thinks) suits the occasion.

In the Cyclops Euripides uses this trait of the old-fertility in devising plans to extricate themselves from embarrassmentas we have seen he used the other traits of the old, to produce a ludicrous effect. Old Silenus no soonel finds limself face to face with the cyclops than all his boldness vanishes, and he shows that he is a past master in the art of devising ways and means to meet an emergency by the enormous lies he tells in quick succession (228-40). According to Silenus, Odysseus and his followers had beaten him (228), stolen the goods, and then boasted that they would "do a plenty" to Cyclops himself if he should come back before they got away (232-40).

Lines 540-89 give a scene where quick-wittedness and great fertility in concocting schemes bring out in ludicrous fashion the weakness of both Cyclops and Silenus-Silenus indulging in liberal potations, finding excuse after excuse (554, 557-8) for not giving the cup to howling Cyclops, and finally gulping down the entire cup himself (564)-all making up a scene which for comic effect would be hard to excel.

In the Antiope it is the old pedagogue who steps into the 
breach and with a quick wit and facility in devising schemes matures a plan which saves Antiope and restores her as mother to her sons. More remarkable even than this and showing even better the fertility of the old in reasons and excuses is the reason he ofters the boys for his previous silence about the identity of their mother. (Frag. Antiope 218. See also Hartung, Vol. II., p. 4.26.)

Again, is it this old pedagogue who concocts the scheme for the punishment of Lycus. The old man plans, the boys exccute. (Hartung, Vol. IT., p. 42S.)

In the I)ictys the old man thiuks he is able by planning and contriving to thwart the wicked purpose of Polydectes. ${ }^{1}$

\section{OLD AGE CONSERVATIVE: YOUTH BOLD AND VEX. TURESONE.}

The next trait of the old which we may observe in the dranas of Euripides is their conservatism. The old are careful and discreet; observant of custom aud established usage to which they cling with a tenacity which is sometimes pathetic. Old age is the time of fixed manners and modes of life. Youth is the time for learning. The nature of the old is incapable of being molded by outside influence; that of youth is plastic and pliable. In this counection compare Supplices (916-17):

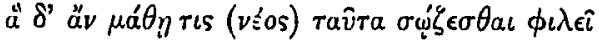

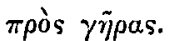

This conservatism of the old is very freepuently brought into strong contrast with the opposite traits, boldness and venturesomeness, which the young display. Orestes in the Iph. Tau., in response to Pylades' suggestion that they renture a bold attack upon the temple during the night, responds,

$$
\begin{aligned}
& \epsilon \bar{v} \gamma \grave{\gamma} \rho \text { eimas }
\end{aligned}
$$

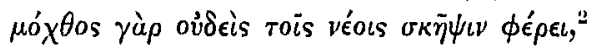

implying thereby that while youth is renturesome, age is careful and prudent. Cf. here Alces. 1053. With this cf. also Hip. 967-9.

In the Supplices this contrast between the conservatism of

'Inc. Frag. 910. Assigned to Dictys by Hartung, Vol. I., p. 369.

2Iph. Tau. 119-22. 
old age and the impetnosity of youth is well developed. Adrastus, bewailing the misfortume which he has brought upon himself, attributes it to the fact that he had yielded to the clamor of the roung men for war against the counsels of the wise Amphiarans (160). Note also lines 282-7. Here the implied contrast between impulsive youth and the conservatism of piper years is well marked.

The high and venturesome spirit of youth is again well brought out by Theseus (44-6). "In a monarchy," he says, "the young men are killed for fear they will not endure tyranny:" Ethral's words (312-13) show well the respect of the old for law and custom.

Cf. also in this connection Creon's response to Eteocles (in the Phoenisse), who, when lie hear's that the Argive host is advancing to battle, wants to lead his army out at once. To this Creon silys (713): "Art so young as not to see what thou ought'st to see?"- that is, "Your youth makes you too venturesome." He adds very significantly: Bovdev́ov (735).

An excellent example of the conservatism of the old and their reverence for established customs which they cling to with a tenacity bordering sometimes on the pathetic occurs in the Orestes. Taking as his text, so to speak, these words,

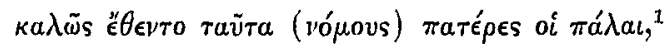

old Tyndareus does not permit himself to condone in the least the crimes of his daughter, Clytemnestra. He hates her for violating the laws and customs of Greece (518-19), and he thinks she has done well in dying for her sins (538). He steels his heart against his grandson, Orestes, and is determined to support the law, so far as in him lies, against all forms of illegality, that "bestial and polluting thing which destroys states and nations" (523-5).

This conservatism, this attachment to custom, is well seen also in the Bacclire. It is the "traditions of his fathers"

1Orestes 512. Even before this, this trait of old Tyndareus' character had been brought out in his reply to Menelaus. Menelaus says: To this Tyndareus responds:

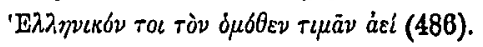

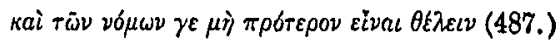


Personal Characteristics of the Old.

and their customs "coeval with time" that he had inherited to which Tiresias clings so tenaciously. ${ }^{1}$ And it is to the "custom current among men" of honoring all the gods to which the $\theta \epsilon p a ́ \pi \omega \nu$ first appeals in lis effort to change HippoJytus' attitude toward Aphrodite (Hjp.90 If.).

In fict, this conservatism of the old, this hesitation to countenance innovations of any lind, is one of the causes why the old are on the side of the established religious order (pp. 1-15). They disliked innovations in all the relations of life.

In the Alcestis the chorns of old men is anxious to know whether the customary arrangements have been made (148). They are also anxious to yerform the customiry funeral rites, the putting on of momining as soon as it is ascertained that $\mathrm{Al}$ cestis must die (215-16). And Pheres, when censured by Admetus becanse he, an old man, is not willing to die for him, says that there is no law or custom requiring it."

In the Ion (808-20) the old man gets excited and indiguant as he thinks (when he hears of Ion's supposed identity) of the "ontraged law of the city and conjugal troth so rudely violated." (Lallier, De la Condition de la Femme, p. 201.) , t? MILDER TRAI'TS.

The characteristics of the old which we have discussed up to this time have, more or less, had reference to stern, unlovable, uncompromising phases of their character. Their garrulity, their excitability, their dissatisfiaction with their present despised lot and their yearning to renew the days of their youth, their conservatism which had a tendency to oppose progressall these were traits which exercise a repellent rather than an attractive influence upon us as we study the delineation of senile character by our poet.

There is, however, another phase of the character of the old, a kindlier, friendlier phase, which Euripides had caught and which he delights in depicting. This kindlier, milder phase of character manifests itself in several ways:

(a) In love for children;

(b) In kindly sympathy for the afflicted and distressed;

${ }^{1}$ Bacchae 201-3. With this cf. the $\nu 6 \mu \varphi$ in Hec. 800 and see p. 2, note 5. 2Alc. 683. 
(c) In lore of peace;

(d) In attachment to friends;

(e) In a keen sense of justice;

(f) In a good-natmed, paternal condescension to younger people.

If we take up these in order, we shall see that these traits of character are much in evidence in the old of Euripides.

\section{(11) Love for Children. ${ }^{2}$}

This is especially frequent in the Phonisse. Old Creon is indignant when Tiresils eren suggests that he give his son as a vicarious offering for the state. He is willing to die himself (968-9), but he cannot and will not give up his son." And his distress as he comes in with the mangled body of Menœceus, seeking ocasta, who is to wash and lay out the body, is very touching (1310-19).

Quite in keeping with this attitude of Creon's is the anxiety which Jocasta shows for her two sons, her eagerness for news from them $(1076,1083-4,1207-8)$. So intense is her affection that she resolves not to survive them (1280-2), and actually does kill herself when she finds that they are dead (1348).

Also at the end of the play, when old OEdipus is introduced he shows this same thotful and considerate love for his child Antigone. Tho he feels bitterly solitary exile (1616-20), yet as soon as Antigone announces her intention to share that exile (1679) he rejects, becanse of his love for her, her offer (1683), and adds: "Do you but stay here and be happy, and I shall verily love my ills" (1685). And the play closes with his making a fint effort to liave her give up her project of sharing his exile with him (1747 fl:.).

In the Meden a rery tonching scene is described by the messenger. Old creon, when he comes in and sees his daughter dying, is so overcome by his fatherly affection that he throws himself upon her, tries to tear the magic garment from her body, and, failing in the attempt, cries out piteously:

1The love of children is not exclusively an old trait. The young display it, but the old show it in an especially marked manner.

?Phœn. 963-4. 


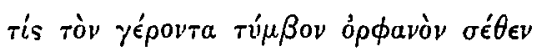

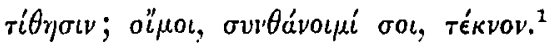

In the Hecula we find this trait of the old, love of children, very extensively and effectively used by the poet. Old Hecuba, when she finds that Odyssens is inexolable, oflers herself as an offering to Achilles, hoping thus to save hel datughter (3857.) And when she finds that $h e r$ death comnot satisty Achilles (389-90) she wants to die with her daughter (391), and she becomes so insistent in her demands to die with Polyxena that she forgets herself and dedares that Odprseus "must" (39)i yield to her demands-il word wholly out of place in a slave's month, as Odysens curtly informs her (397).

It is vely fouching to see the excitement of old Amphitryon in the H. F. when he thinks his son. Hercules, is going to kill him-an excitement due not to his fenr" of death, but to his anxiety lest his son by killing him incme the guilt of patricide and thus increase his sorvow (1072-(j). This tender solicitude of old Amphitryon for Hereules is further hrought ont in the touching scene (1111-15) where he parries Hereules' questions and does not want to tell him the whole truth, in order to spare him as much as possible.

With this al', the secne of ('adnums in the Bacche (1287-8) where he hesitates to tell Agave the ruth, lest the shock might "retard her recovery from madness."

In the Troades a mother's pride secs the cause of Helen's choice of I'aris' heanty."

Orestes tells us that oid Tyndareus and Leda carried lim when a child around, taking as much pride in him as in their ox" childich (Orestes 4(60-5)).

Med. 1209-10. Mader, in his work entitled, Ueber die Hauptsaechlichsten Mittel, mit denen Euripides èneos zu erregen sucht, p. 37, well points out that from the first Creon displays as one of his more characteristic traits Liebe $z u$ seiner Tochter, and calls attention to lines $282 \mathrm{ff} ., 328.9$ as cases in point. Mader does not, however, seem to see that this "Liebe au seiner Tochter" is a trait of old age in general, and not anything particularly noteworthy with respect to Creon alone.

"Decharme thinks this scene amusing (p. 254).

iTio. 987-8. 
In the Andromache note Pelens' affection for his grandson, Molossus. Cf. lines 722-4 especially. ${ }^{1}$

In the Supplices it is touching to see Iphis' devotion to his children. He feels he cammot live when Evadne dies (1073).

In the Heraclidie the love of her grandchildren lats led Alcmene to endure grent hardship in flight and exile for their sake $(41-3)$.

In the Polyidus, Minos is so infatuated with his son, Glancus, that he desires to renew his youth, so that he may the longer love him (Hartung, Nurip. Rest., Vol. II., p. 21t).

\section{(b) Kindly Sympathy for Afflicted and Distressed.}

This is one of the most tonching traits of the old. They are very sympathetic. Even the bare thot of sorrow often moves them to teans. Tyndarens in the Orestes declares that, tho he did not see the alwful sight of Clytemnestra's murder, yet the mere thot of it melts his old eres to teals (528-9).

In the H. F. the old men of the chor'ts are mover to bitter tear's when they see Megal'a, her children, and the old man, Amphitryon, coming forth dressed for death (4-17-50).

In the supplices, Adrastus shows a tine sense of feeling for the distressed supplices. His heart bleeds for the poor mothers denied, with more or less insolence (942), a last look at their dear sons, and he turns to them with the consoling words: "Never" mind. Yon must endure this (new grief) patiently. It is probably better so. Severtheless you shall have the ashes of your dealr ones to carry as a solace with you to your homes" (947-9)).

In the beginning of the play, too, this sympathetic trait of the old is well bronght out by contrast. Fthra, the old mother, is easily and at first sight mored to pity for the distressed state of the Suppliants, while Theseus, the bumptious youth, has to be overpersunded by his mother before he will adopt a friendly and sprmpathetic attitude toward them (301 if.).

Cf. here Creon in the Medea. Tho he feared Medea (282 ff.)

1 Patin calls attention to this affection of Peleus for Molossus, Vol. III., p. 75 , and adds: "En qui (Molossus) le vieillard, malgré l'illégitinité de sa naissance chérit un rejeton de sa race." 
and thot it best to exile her immediately from the land, yet he is so moved by the sight of her distress that he pities her and permits her to remain. Note his words as he yields (345-9).

In the Hippolytus the animating impulse of the nurse's activity in Phredra's behalf is her excessire sympathy for her mistress in her great distress. The nurse herself says (250. $60)$ : "I grieve excessively for her."

In the Andromache old Peleus is moved to tears as he unbinds Andromache's hands and sees the bruises the thongs had made (719). See page 39.

It is this feeling of sympathy for the sorrows of others which is in part the canse of Iolaus and Alcmene in their advanced old age undergoing so much distress and hardship for the Feraclida. For other catuses which inpelled them to the sacrifice, see piage 70 , etc.

An excellent case of this sympathy for the distressed which the old feel occurs in the Antiope. Antiope, belored by Zeus, imprisoned by Lycus her uncle, cruelly insulted by Dirce her aunt, then a fugitive on Citheron, starving. tired, in mortal terror lest she should be appreliended and returned to her cruel aunt and uncle, scorned as a mópr $\eta$ by her as yet unknown son from whom sle asks protection and help, presents a sorrowful and pitiable spectacle. It is at this juncture that an old man-he who had found her exposed sons some years before and had reared them-appears upon the stage. He is instantly touched by Antiope's wretched plight; and her whom the youth, Tethus, had spmened and upon whom her wretched condition made no impression, the old min no sooner sees thim he pities and plans to help. ${ }^{2}$ His pity for her leads him into a violent quarrel with the queen and later into the breaking of a firm resolution ${ }^{2}$ which he had formerly made.

Another excellent illustration of this trait of the old is seen in the GEneus. Old oEneus had been wretchedly treated by Agrius-had been deprived of his kingdom, forced into

${ }^{1}$ Hartung, Eurip. Rest., Vol. II., p. 425, says: "Senex, cui salus miserae cordi erat."

2He had resolved not to tell the boys the woman was their mother. He breaks this in his zeal to rescue Antiope. 
wretched servitude, and made to sulfer inmmerable distresses. Yet in spite of this, when restored to his kingdom by his grandson, and when Agrius is completely in the latter's power, such is the lindly sympathy which the old felt for sorrow and distress that OEneus, much to Diomedes' chagrin, forces the latter to be mild in his treatment of his prisoner and to content himself with the punishment of exile.

Likewise in the lictys it is old Dictys who, touched by the suffering of Danae, ${ }^{1}$ stands forth throut the drama as her companion and defendes.

\section{(c) Love of Perece.}

The old in Euripides are the peace-lovers, the advocates of arbitration, not of war. Other chanacters necasionally talk of the advantages of peace, but their words lack the depth of feeling and conviction which the words of the old evince.

An excellent illustration of this trait of the old is found in Erectheus, Frag. 370. Here the chorus of old men having just wituessed the dire sacrifices which war exacts (a royal daughter slain) breaks out in a touching ode to peace.

Kresphontes, Frag. 462 , is another excellent case in point. Note the depth of pithos in this priyer of an old chorus to loitering peace.

Note also the earnest feeling in Adrastus' words (Sup. 744$9)$. This advocacy of peace is with him no mere passing fancy, but is his principle of life. As the corpses of the dead heroes are abont to be carried to the lyre, Adrastus, feeling that a sight of the bodies of their sons, even tho they are but lifeless. bodies, would be some halm to the aching hearts of the wretched mother's, says to them (sup. 941): "Approach, ye sorrowing mothers, and take a last fond look." As these grief-stricken matrons, bowed down by their grief and length of years, are about to approach the bier, Theseus restrains them, curtly

${ }^{1}$ Hartung, Vol. I., p. 539, commenting upon the protection which Licymnius gave to Alcmene in the play by that name, says he did it quamvis sencx. Had he said, cum senex esset, his expression would have been more exact.

2The tallative herald in the Supplices remarks on the advantages of peace (486-493), but this is more in the nature of an academic discussion than an expression of deep conviction. 
chiding (note the presumption) gray-headed Adrastus (Sup. 942). Adrastus, seeing the haughty demeanor and excited mien of Thesens, and indulging his natural peace-loving natmre, yields to Theseus with the courteous remark: "You are doubtless right (vicîs)." He thus, by means of excellent judgment and self-possession which a young man would hardly ever have shown (in Euripides), prevents what could easily lave developed into a disgraceful quarrel in the presence of the dead. And a little later on he breaks out into a pathetic apostrophe to wretched men to cease from war (Sup. 949-52).

Also in lines 2:32-7 of this play the palcific nature of the old, its thotful care of other's, etc., is brought out by sharp contrast with the opyosite traits of the young.

It is because the old are peace-loving that we find them the peacemaker's in quarrels and disputes. In the 1 ph. Aul. Clytemmestra tells us that it was her old father who interposed in the feud between her and her brothers on the one side and Agamemnon on the other to allay the strife and to bring about a reconcitiation (1. A. 1155). It was the same old man who, we tind, by prudent forethot sought to keep everything peace. ful and hamonious among the suitors (I. A. 55-(i9).

In this comnection cl'. Jocasta in the Phon., who is the gobetween in the pacific overtmes between the brothers (435 ff.).

In the Alcmene it is the anged Alcmene who seeks to allay the discord between Tlepolemus and Licymnius. And it is Licynnius who, tho roundly berated by Tlepolemus for his lack of spirit, prefers to endure his present unfortmnate condition rather than to seek redress by arms (Hartung, Vol. I., pp. 5:38-9).

Cf, in this connection the cliorus of old men in the Heraclidx how peace-loving they are. (See p. 33.)

\section{(d) Attuchment to Friends.}

The old display in marked degree this lovable trait. The old servant in the Electra, as he comes toiling up the steep bank (489-900) bringing supplies to Electra, in response to her summons (40!) says: "For one's friends one must endure a bent back and tottering knee." (Elec. 4!)1-2.)

In the H. F. the chor'us of old men pride themselves on their fidelity to their friends. They tell Lycus not to call them busy- 
bodies because they take the part of their friends (266.7). Cf. here the words of the old man in the Ion (935) :

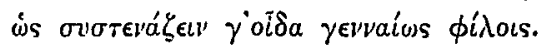

Note also lines 850-3, where he expresses his willingness to die if only he can arenge the wrong Creusa has suffered.

In the Phon. the old pedagogue show's great solicitude for the fair name of Antigone. He wants her to tarry before going out upon the walls long enough for him to assure himself that there is no one to see them (92-95). And again when he sees the chorus of romen coming up to the house, he urges her to go in lest they talk of her. ${ }^{1}$ With this ct. the words of the nurse in the Hippolytus (212 fi.).

In the Helen ( 726 if:), Hedea (5t), I. A. (30t ff.), old serrants descant upon their fidelity and attachment to their masters, while in the latter, als Nestle sily's," "rechnet sich der alte Haussklave den Vor'wurt' 'allzugrosser Treue, den ilm Menelaus macht, zur Fhre an, und der Kilytaemnestra gegenueber bezeichnet er sich als 'ihr und ihren Findern wohlgesinnt' (867). Die Brohnung des Menelaus beantwortet er mit der Versichermg. dass es finer einen Sklaven Nichts Ruhmvolleres gebe, als fuer seinen Herrn zu sterben" (312).

Iolaus in the Heraclidae is an excellent eximple of the warm attachment which the old show their friends. He tells as himself that he could have been living quietly and safely at home, but he chose to share all the affliction of the Heraclids because of his former attachment to their father" $(6-11)$. And the old fellow stops at nothing to belp his friends, even oflering himself as a vicarious salcrifice for the Heraclidie and Athens. ${ }^{+}$

1Phœn. 193-201. This love and solicitude here and elsewhere shown by old slaves and servants for their masters is separate and distinct from the enforced obedience of slaves to their masters, which is everywhere in evidence and which was the lot of a slave. It is this enforced obedience of slaves to their masters (not the attachments they show to friends) of which Nestle is speaking when he says (p. 352, Duripides der Ditcher der Griechischen Aufklaerung): "Der Sklave hat nichts zu thun, als den Willen seines Herrn zu erfuellen: seine einzige Tugend ist der Gehorsam."

"Page 357, Euripides der Dichter der Griechischen Autklaerung.

$3 \mathrm{Cf}$. with this the sorrows which Licymnius and Alcmene endure in the Alcmene for the salie of the Heraclidx. (Hartung, Vol. I., p. 537.) 4 Heracl. 453-5. 
Note also his words when he announces his purpose to go and join the army himselt: ${ }^{1}$ Note also Tyndareus' eagerness to see Menelalus (Ores. $474 \mathrm{fi}$.).

\section{(c) A Keen Sense of Justice.}

The old have a keen sense of justice and of the fimess of things. Old Amphitryon in the Her. Fur., remembering Heracles' benefactions to Greece, thinks it unjust that Greece in turn does not defend his children, the Heraclide ${ }^{2}$ (217-26).

In the Cyclops old silenus in the prologue feels that his former services to Bacchus ought to gan for him a requital far different from his present degrading and distressing service to the man-killing Gyclops. Cf. the whole prologue in which he "querulonsly describes the troubles which he has had to endure from his early youth until now in the service of Bacchus," with the words of the chorus (76-81), which we may properly take as reprewenting Silenus' thots.

This trait of the old is forcibly brought ont in the Eolus. In that play Macareus becomes enamoured of and then debanches his sister, Canace; no sooner does the old father, Folus, find this out than, with a keen sense of the right and fitness of things, he sends her a naked sword. Canace acts upon the hint and commits suicide.

Cf. also Alcmene in the Heraclidie when Eurysthens comes under her jower. The eternal fitness of things makes this just

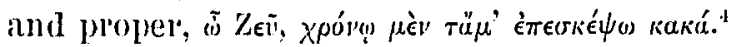

Cf. also Polymmestor hefore Hecuba in the latter part of the Hecuba.

Cf. Tyndareus' attitnde in the Orestes. His keen sense of justice caluses him to see that tho (yytemnestra is his own danghter, yet she met a just fate in dying (Ores. 538).

1 Heracl. 680-1.

wOther characters express sometimes the same thot-e. g., Mousa in the Rhesus. She thinks that in retum for all the honors she and her sisters had heaped upon Athens she should have got better treatment from Athene than the death of her son. (Rhe. 938-48.) Cf. also Ion. (364 ff.; 439-443; 449-451; 906).

"Paley, note to line 1.

${ }^{4}$ Heracl. 869. 


\section{(f) A Good-Nutured, Paternal Condescension to Younger People.}

The old were inclined to look upon younger people, no matter how old these may themselves be, with a good-natured, patronizing, and paternal condescension. They seemed to think of younger people as still children, so that when they addressed younger people they seldom" called them by their name, but instead they used the terms "son" (

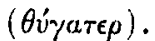

In the Helen no somer does the messenger find ont that he is talking to the trute Helen than he breaks out into a long speech, the first word of which is Av'yarep (711).

In the Troades Hecubil addresses the chorus tékvov (160, et

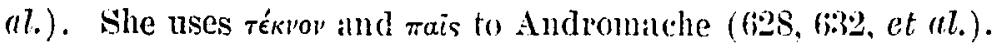

In the Supplices the chor'us calls Theseus térov ( 282 , ot al.).

In the Ion the old man addresses Crensal with biryatep (735, 763, 925, 942,970, 998), with rékvov (765), with $\pi a i$ (1018, et al.).

In the Hipl. the nume aldresses Phredral with $\pi a i \quad(212,238$,

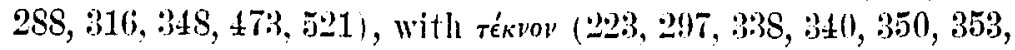

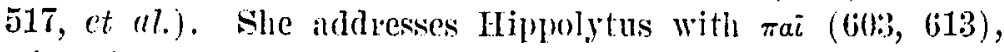
with $\tau^{\prime}$ kvov (611). And so on throut the other works.

This habit which the old had of looking upon younger people as still children, no matter how old the gounger person may himself happen to be, explains a passige in the supplices which has given much trouble." Adlustus calls himself in line 166 modiòs ávip. In 250, however, the chorus spenk of him as a véos.

The chorus, being composed of the mothers of Adrustus' compmions, and heing therefore much older than Adrastus (tho he is old enough to have a gray beard), chamateristically speak of him as a véos, and say with good-natured indulgence: "Youth is full of error"; therefore pity him" (Sup. 25(1)-1).

IIn the Alcestis, bowever, the chorus of old men always address Admetus by his name, except in line 674. But see p. $77 \mathrm{ff}$.

2Dindor'f gets around the trouble by omitting the former verse (166). Paley endorses this in his note to line 250. Murray, however, in the Oxford text, gives both lines.

3It must be remembered tho that Adrastus was not very aged, for he speaks of himself in line 738 as still among the irim $\beta / a x^{i n \sigma a n}$. 
Cine 674 of the Alcestis, which has also given much trouble to commentators, becomes natural and regular when we remember that the old address younger people with a good-natured, condescending $\pi a i$.

It is objected" that the word mai is "unsuitable in the mouth of courtiers addressing their king." These old fellows, howevel, simply yield in this instance to their natural bent and quite instinctively" nse the word $\pi a i$, even tho they are spenking to "their king." And this view proved the more likely inasmuch as in the Heraclide lolaus, a refugee seeking asylum at a foreign court, aldresses King l)emophron with this very term $\pi a i^{2}(381)$.

If there were anything "munatural" in such a use of the word, the unnaturalness would be here rather than in the Alcestis. In both cases, however, the old fellows are merely yielding to that natural tendency which the old everywhere show in Euripides of looking with more or less patronizing condescension upon all younger people, no matter what theil age or lank, as still youths.

Result of These Milder Traits.

'These milder traits of character which we have just discussed-love for child'en, kindly sympathy for the afflicted, love of peace, attachment to friends, a keen sense of justice, a goodnatured condescension to yomger people-made them beloved in spite of the harsher side of their natures. Those around them saw these nobler attributes of the old; and forgetting or overlooking in great measures their irritating peculiarities, looked upon the old in many cases with a reverent, ${ }^{3}$ if not with an atfectionate, feeling.

1Jerran: Alcestes, Intro., p. xxvi.

2Paley's comment on this line is: "The age of Iolaus entitles him thus familiarly to address the young ling."

3 In the Eurystheus, Frag. 364, line 21, a youth is advised to shun

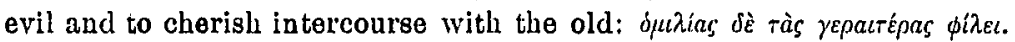
Lallier (De la Condition de la Femme, p. 210) cites, when speaking of les parents du mari, Plato's Laws, XI., p. 931, and says of the passage: "Platon nous présente la vieillesse sous l'aspect le plus vénérable. Un père, un aïeul, chargés d'annees ne doivent pas nous être moins sacrés que les statutes des dieux. Ces aïeux, que nous avons dans nôtre maison . . . sont les images vivantes des dieux." 
In the Hippolytus, Thesens, when he thinks that the wailing in the palace is for Pittheus, says (Hip. 794-(j): "Tho he is very old, yet I should grieve much if he is dead."

In the Orestes the sight of old Tyndareus arouses even in the heart of the crazy murderer, Orestes, a recollection of the lindness Tyndareus had shown him when a, boy and the especial reverence for the old man he hat felt and still feels because of this lindness (Ores. 459-(61). Agatin, in lines 548-50, he refers to this reverence and awe which he feels for Tyndarens. In fact, Orestes' whole attitude at first is one of alfection and reverence.

Compare here the affection which we are told Pentheus showed to old Cadmus; how he protected him, taking upon himself and avenging the insults offered to Cadmus (Bac. 1311 . $13,1319-24)$. He is even restrained from proceeding to violence toward Cadmus because of the reverence which he feels for his old age (Bac. 25s.60).

Such devotion and care must find its fullest explanation ${ }^{1}$ in something more than mere custom" or pity felt for the danger: to which the old were always liable of being abused and maltreated. (See p. $34 b$; also pp. 35-36.)

Note also the tender care which Theseus (tho somewhat officiously and vauntingly) shows to old XEthra in the Supplices (359-62).

An excellent illustration of the reverence which the old inspired and the consideration with which they were often treated occurs in the H. F. Hercules asks of his father (533):

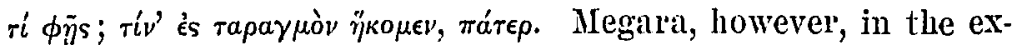
citement of the moment, answers the question herself. The next. moment, however, seeing the discourtesy she has shown to old

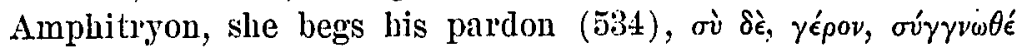

\footnotetext{
${ }^{1}$ Fustel de Coulanges, in La Cité Antique, pp. 108-9, says: "Et voyez quel lieu puissant la religion établit entre le père et le fils! Les anciens donnaient aux vertus domestiques le nom de piété: l'obéissance du fils envers le père, l'amour qu'il portait à sa mère, c'était de la piété . . .; l'attachement du père pour son enfant, la tendresse de la mère, c'était encore de la pieté . . . Tout était divin dans la famille."

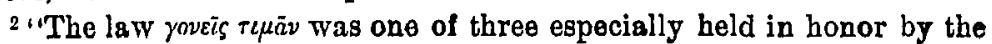
Greeks. See Frag. Antiope 221." (Paley, note to line 362 of Supplices.)
} 
$\mu o$, attributing her discourtesy to the frailties of her sex (5.556.) A little later on Hercules is amazed to find that Lycus had so far forgot himself as not to have any scruples against dishonoring the old man, Amphitryon. ${ }^{1}$

It is interesting to note in conclusion that this love and affection which the old were often the recipient of was especially pleasing to them. Consequently Euripides has them show that they liked to be loved and caressed." Note the pathetic words of old Iphis in the Supplices (1101-3): "An old man loves a daughter rather than a son, for a daughter fondles him the more."

1H. F. 556.

-Lallier (De la Condition de la Femme, p. 212) says: "La vieillesse, comme l'enfance, a besoin d'être choyée et caressée; il ne lui suffit pas de se savior aimée, il faut que cette affection qu'on lui porte se produise en vives démonstrations, qu'elle se prodigue en tendres paroles et en prévenances délicates." 
PART TWO.

DRAMATIC CHARACTERISTICS OF THE OLD IN EURIPIDES.

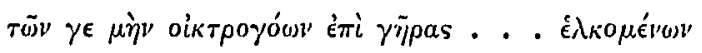

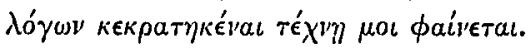

(Plato, Phachlus, $26 \%$ c.)

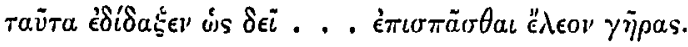

(Hermias, 238: 18.)

6 


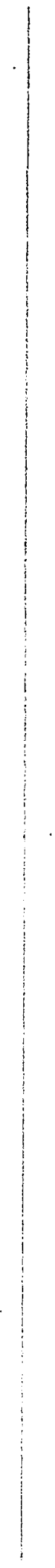




\section{DRAMATIC CHARACTERISTICS OF THE OLD IN EURIPIDES.}

Hawisi now analyzed the pelsonal challateristics of the old in the dramas of Euripides, we come to the secoud division of our subject, as stated on page xiv: A deduction therefrom (i. e., from the personal trats) as to their drenmatic characteristics-i. c., the function the'y discharge in the movement of the drama.

It was said on page xiii that the old hat marked dramatic characteristies-that is, whencere Euripides wants to produce certain effects he uses old people, and the more desirons he is to produce these effects the more certain he is to give old men and women important roles in the play.

What then are these effects which Euripides produces by his use of old characters? Pathos, deep and profound; sorrow, heart-breaking and crushing; pity, compassion, sympathy. Our poet uses the old in his most tragic parts to intensify the tragedy and to increase the pathos of those parts. This effect the personal traits of the old, their excitability, their garrulity, and repetition," the danger of sulfering abuse to which they were exposed, cte., combined with their milder phases of character, their love of children, their love of peace, ctc., were especially calculated to produce.

Euripides perceived" this and made use of the old with their stern and unbending traits, together with their milder and

1 "A striling characteristic of Euripides' plays is the appeal they make to human pity," says W. H. S. Jones in The Molal Standpoint of Euripides, p. 18.

"Ludovicus a Sybel, in De repetitionibus verborum in fabulis Euripideis, p. 11, says: "Earundem vero vocum pathetica quaedam assiduitas cantica decet imprimis timentium, lugentium, magna laetitia exsultantium."

:Ludwig Mader, on the other hand, in his inaugural dissertation (1907) entitled, Ueber die Hauptsaechtlichsten Mittel, mit denen Euripides $\ddot{\varepsilon} \lambda_{\varepsilon \circ \varsigma} \mathrm{zu}$ erregen sucht, p. 58, thinks that Euripides was intellectually dependent, or, in the exact words of Mader, that he had a "geistige Beruehrung," for much of his power in depicting pathos upon the "models of sympathy-"Schlabonen des Mitleids"-which the Rhetor, Thrasymachus of Chaledon, was turning out about this time. 
gentler characteristics, to work upon the srmpathy of the audience and to excite and to maintain the feeling of pity and fear, ${ }^{1}$ which Aristotle says ${ }^{2}$ is the sum of tragic composition.

The greater the number of the old in any play and the more prominent these old characters are, the deeper the sorrow, the more intense the pathos of the plays and the greater the

1Conradus Haym, in his paper, De puerorum in re scaenica Graecorum partibus (Dissertationes Philologicae Halenses, Vol. XIII., pars 4), says on page 293: "Sed addendum est alterum artis Euripideae proprium atque ipsum quoque ab Aristophane saepissime castigatum" (Ach. 413; Pac. 146 ff.; Ran. 1063 ff.). "Illud dico quod in excitanda spectantium misericordia summum posuit studium; inde pannosae illae, mendicae, claudae personae, quas acerbissimo risu comicus exagitat." To the pannosae illae, mendicae, etc., Hayn could have added with great propriety and truth, maximi natu. In fact, Haym seems to have partially observed that Euripicles used the old to arouse the emotions of his audience, for he says, pl. 2S9, 290, of the paper above referred to: "Non sine ratione quidan (pueri) mihi coniecisse videntur . . . ut spectantium voluptati inselvirent. . . Negari nequit, ad misericordiam movendam omnes fere tragicos pueros. . . esse aptos. Qua cum arte aliud artifcium proxime cohacret: hoc dico, Euripidem mininos nalu cum maximis, $i$. c., senibus aetate iam decrepita, saepe coniunsisse eaque imagine. qua vitae humanac fines artificiose consociatos ostenderet, callide studuisse spectantium sensus moverc atque sibi conciliare. Dechajme in his strong cliapter" on "Pity" (p. 1.90 ff.) barely misses this function of the old which we are discussing. He says: "The pity which. . . tragic character's inspire has its source not merely in the situations, . . . Jut sometimes it results also from their sex and their age." He then enters upon a long and illuminating discussion of the function of childven in Euripides' dramas to arouse a feeling of pity, but he does not say anything about the old. Elsewhere he says (p. 169): "Euripides, even from the beginning of his career," seems "to have treated themes in which tragic terror was carried to the extreme limit." It is interesting to note that Decharme makes this statement after he has described the Peliadesa drama in which the butchery of an old man is the central theme.

2Poetics XIII., 2, 6. Tragedy "must imitate actions which excite pity and fear, this being the distinctive mark of tragic imitation; . . . and Euripides, faulty as he is in the general management of his sub-

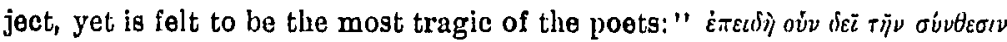

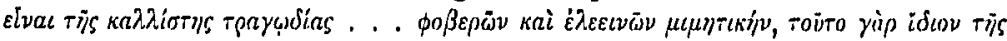

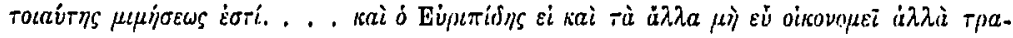

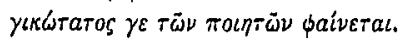


feeling of pity engendered in the andience. We may state the proposition thus:

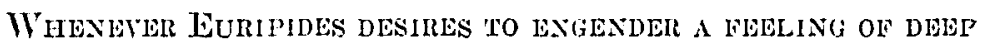
PITY IN HIS ACDILNCE OR TO POHTRA somow PROFOUND AND

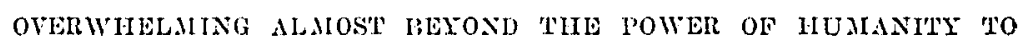
BEAR, HE MAKES AN OLD peRson (OR OLD P'EOPLE) THE CENTRAL FIGURE IN A SCEXE OR PLAX. ${ }^{1}$

The Heculoa and the Troades furnish us with excellent examples of the use Furipides made of the old in his dramas. In these plays, overwhelming grief, accumulated sorrow, poignant distress are to be depicted, and the leading character in both is the same old woman, Hecubl. So distressing in fact ate these plays that the latter has even been criticised as being too tragic and terrible. Schlegel remarks" that "the eliort of the poet is overdone; when all is hopeless gloom and wretchedness, the sentiment of compassion becomes wearied, exhausted, and palled by excess." In no other play by our poet is there such woe as in these two, and in no other does an old character play such an important part. We will look at each more closely.

In the Hecuba an aged, decrepit figure, Hecubi: hersell, is introduced; one time queen, but now, by the vindictiveness of some god, a slave (55-8). So pitiable is this figure as it hobbles over the stage, leaning on a crooked stall (ib-7) and supported by attendant slaves (62), that the spirit of Polydorusbut lately come from the hiding place of death and the gates of dalliness (1), and who we may confidently suppose was

1After 58 pages of "Ways" which Euripides used for arousing sympathy, in which is included everything possible, it would seem, except

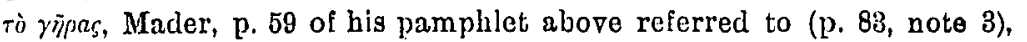

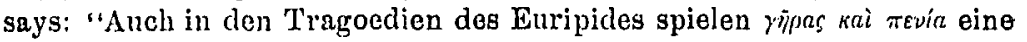
grosse Rolle!" With which statement he is content to leave the mattel.

2Quoted by Paley, Vol. I., p. 446.

3"Reine tombée dans l'esclavage, mère privée de presque tous ses enfants, Hécule ne survit à sa grandeur et à son bonheur que pour voir trainer an sacrifice la fllle qui était sa dernière consolation, et pour découvrir la mort du plus jeune de ses fils," is the way Weil (Notice sur la fable et sur la date d'Hécube Sept Trag., p. 204) describes this distressing figure. And Hartung, Eurip. Rest., Vol. I., p. 504, says: "Qua (fabula) Hecuba haud facile ulla magis tragica invenire potest." 
well accustomed to sad and piteons sights-could not contizin itself, but even at the first sight cries out in anguish and deep pity (55). Such being the effect of the appearance of this aged Hecuba upon a risitor from the other world, we can well believe thit no less pity and distress is aroused in the breasts of the andience. And this pity is much increased by the excitement (61), the feil (6!)), the agonizing prarer (79), the impression of impending woe (8:3), and by the lumors which reached her from the Grecian camp (9).

All these emotions-excitability, terror, religions fervor (all senile traits, as we have shown-atfect the andience profoundly. It becomes intensely simpathetic toward Fecuba. This sympathy is increased by the long and distressing scenes in the next 100 lines-the chorus in the patodos announcing the newly decreed sorrow (100)-5.), then Hecuba, again utterly unnerved and helpless, reproalching herself for her age and servitude (155-72), and calling out her daughter to hear the news (172-7). The andience fully agrees with the chor th when it says: "Surely no man is so callous as not to doop a tear for her woes" (2!)(i-8).

The emotions of the audience are now all in play and enlisted on the side of Hecubs, so that in hep collonuy with Odysseus and later in her plea before Agamemnon, first for help and later for judgment against her enemy, Polymuestor, the sympathies of the audience never swerve from the object upon which the poet intended them to be placed. Thruout the play these sympathies are on Hecubal and her woes. Talthybius (488), the servint (658-60), the chor'us (689-98), 721-2), and Agamemnon (1243-8), ot al., all show that sympathy for Hecuba is sustained thruout.

Turn now to the Troades. The leading character of the drama, Hecuba, describes hersell as a ypais (1+1), 490 et al.), a "drone" (192), a "feeble image of the deald" (193), "needing a stafl to lean upon" $(27 t)$. Onl attention is first directed to her and her distress in the prologue where Poseidon speaks thus of her:

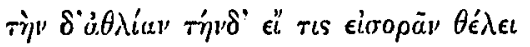

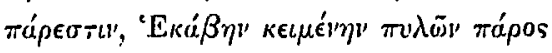

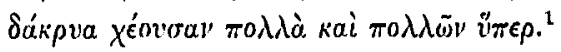

1Tro. $36-8$. 
Dramatic Characteristics of the 0ld.

This passage is the index of the play. The rretched old woman, lying before the gates (:37) shedding bitter tears, is the central figure, and draws ont our emotions thus early in the play. Her long monody (98-152) and her dialogue with the chor us (153-96), in which she bewails and amplifies her misfortunes, make us aware of her lamentable condition. We feel ever-increasing pity for the poor wretch who tries to adapt herself to her present state (101-3), but whose exhortation to herself to "sail with the current" (10:3) only serves to bring before us more vividly the great change which las come upon her. Her place in our feelings is secure. The succeding portions of the drama only intensify our sorrow and overwhelm us with gloom. Her dread to see her paving daughter who is to be insulted by the Greeks (169-75), her fear of slav. ery and hel uncertainty with respect to it (190-6), Cassandra's wretched fate (251), Polyxena's death, her own degradation in being allotted as captive to the most inveterate of her foes $(278)$, etc.-all are points elaborating in quick succession Hecuba's intolerable fate. We ourselves feel her agony as she exclaims:

$$
\begin{aligned}
& \text { ӥраббе крйта ко́тренои }
\end{aligned}
$$

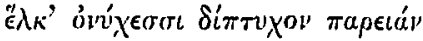

$$
\begin{aligned}
& \text { ió } \mu \text { oí } \mu \circ \mathrm{c}
\end{aligned}
$$

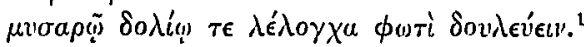

And her appeal to the chorus (2SS) could fittingly have been made to us. The efrect upon the audience must have been very

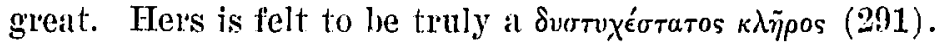

Moreover, throut Cassandrals "wild and frenzied strain" (308-40), we think not so much of Cassandra herself as that she is Hecuba's daughter. It is Hecuba's distress which is intended to be stressed." Her grief is overwhelning, and she

3Tro. $280-3$

2Paley.

"Cassandra is introduced by these words:

$$
\pi a \bar{s} \dot{\varepsilon} \mu \grave{\eta}
$$

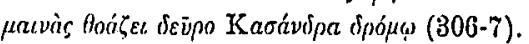

They give the turn to the ode, and Cassandra's continued appeal to her mother not to weep $(403-4,458)$, who was all the time weeping bitterly in full sight of the audience, keeps oul attention upon Hecuba as the central figure. 
falls to the ground exhansted $(462 \mathrm{fl}$.). We believe lier when she says:

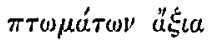

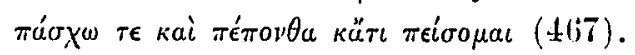

The drama is continned along these lines. Hecuba is ever before onr minds, even tho she is herself not speaking. Her decrepitude, her helplessness, and her senile traits act as foils, so to speak, to bring ont the overwhelming distress which it was the poet's purpose to display. Even when Andromache is speaking. we do not forget that she is but the danghter-in-law of Frecuba. Andromache's sorrows are overshadowed by the greater sorrow of Hecuba-greater because they fall upon a weaker and more enl'eebled head and make, for this reason, a deeper impression upon the andience. Lines $620-1,791-8$ show the overwhehning distress which she felt.

The pathos of the play, which has thus been engendered, is kept alive by the same means by which it was developed. Heeulat remains the central figme and her woes multiply. Her'

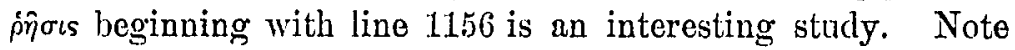
that it is an old woman, the victim of mucle accumulated distress, who has one blow alter another befall her, that the poet uses in this scenc whose only purpose is to develop pathos. ${ }^{1}$ As she stands npon the stage, an old, bent figure, excitedly apostrophizing the shicld (11)-1), the protector of her son, Heetor, on many a field, with the corpse upon it, fondling the dear lead (1178-5) and the hands (117s), the month (1.180), garrulously quoting the well-remembered prattle of the dead boy (1182), (alling attention to her own delenseless state (1185-6) -all this makes a scene diliticult to be surpalssed in pathos, and one especially calculated to move the heart of the audience to pity."

As the play closes with the old woman bedecking with many grouns (1218-26) the corpse and shield, with the burning and destruction of 'Troy before the eyes of her, its former queen

\footnotetext{
1 Paley says (note to line 1156): "These lines (the whole $j$ mrocs) were evidently penned with an effort after pathos of the highest kind."

2"Posuit haec Hecubae lamenta Longinus Fragm. VIII, numero eorum quae miserationem movere vehementissimam valerent," says Hartung, Vol. II., p. 274.
} 
(1260, 1295, 1325, ete.), with her herself carried off the stage (1329)-30) as a slave to Odyssens (1270-1), ${ }^{1}$ the pity of it all overwhelms the spectators, and they cry out with Talthybius

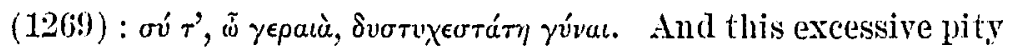
and compassion which have heen felt thruont the play were engendered, sustained, and perfected by the simple expedient of helpless age being made the object of an uninterrupted stream of misfortune.

The Plhenissa is another good example of the principle stated on page 85. that whencver Euripides desired to portiay deep sorrow, almost beyond the power of hmmanity to bear, he makes use of old people. Jocasta, Tiresias, Creon, and at the last Cedipus himself are old people, and the play which is boilt up aromd them is tragic in the extreme."

The central thot is the doom of old Gelipons fand his descendants) becanse of his unwitting sin. All the characters suggest this central thot to us by virtue of their relationship or other close connection with the wretched CEdipus; and the continued references, thruont the play, to his woes permit us never to lose sight of the blind and wretched old man inside the palace walls. Jocasta and Creon and Tiresias, therefore, in addition to the deep and profound distress which their own plight revenls to us, intensify the gloom and pathos of the various scenes by these continued references to the unseen (Edipus. Fol example, old Jocasta, after refering to her own shorn head and tattered latgs of mourning (322-6), describes very lengthily the blindness and grief of CEdipus (327-36). She wants to know moreover the result of the war (1086), in order that she may go within and rejoice the heart of the old man, Edipus. Thruout the play lindred references are made to him $(376-7,1243,1331,13 \pm 1$, et multa alia). The obvious purpose of these repeated references to this wretched old man is:

ICf. Tro. 279 ff., etc.

2Sic haec tragoedia, in qua satis erat duos mori, duas insuper habet non necessarias mortes (Hermann: Praef. Phœn., pp. xxiii-iv.).

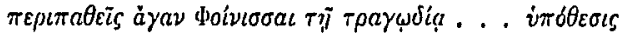
'Aplotoфávous. 
(a) To intensify the gloom of the tragedy and to make us shudder the more at the fratricidal strife;

(b) To prepare the way in this more than tragic tragedy for the final scene where Euripides (or the interpolator who is universally acknowledged to have been thoroly Euripidean) exhausts his tragic possibilities by heaping up "pathos upon pathos, and doom upon doom."

Not content with the death of Menweens, Eteocles, Polyneices, and Jocasta-surely enough, and more than enough, to make this a most tragic work-Euripides introduces upon the stage in the final scene the old blind Gedipas himself. Nothing conld be more distressing than the sight of the old man, bedridden (15:1), a mere breath (1544), a corpse from below, an evasive dream (1545) as he calls himself, led by his daughter," f'urther afllicted and bowed down by the sad tidings which Antigone has to convey $(1546)$, and, last of all, exiled from his native land (158!) with no escort near (as he thinks, 1616) to guide his blind path. Euripides' purpose in thus bringing adipus upon the stage was to intensify the gloom of the play, a thing which the introduction" of the old always did, in order to close this very tragic play with an episode which should exceed in pathos all the many pathetic scenes that had gone before. Antigone, speaking for Euripides, is at pains to give

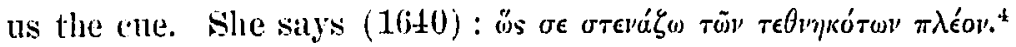

1Verrall, Eurip. the Rationalist (p. 244), says: "I talie the close of the Phœnissie. . . to be one of the most pathetic passages in the history of literature." A statement none the less apt for our purpose because macle to support an allegorical interpretation of this scene. Muff, Eurip. Phœn. Einl. (p. xx.), says: "Ihl (Oidipus und Iokasta) Auftreten fuehrt zu den ruehrendsten Szenen . . . dazu gehoeren die Angst der Mutter . . . und . . . ferner das Erscheinen des blinden huelflosen Koenigs, seine Wehlilage und seine Verbannung." Prof. Kochly says the appearance of the blind old man "hinterlaesst den furchtbarsten Eindruck." (Eur. Phœn. Einl.)

2 Paley calls this a tragic device which was sure to inspire awe and commiseration in the audience, note to line 1539 .

3Cf. this scene with the episode of Iphis and Evadne in the Supplices (p. 97).

tThis final scene of the Phœn., therefore, when viewed in this light and in connection with the Iphis and Evadne episode of the Supplices, is shown to be, not as Aristophanes says, "thrown in to no purpose," $\delta \iota a \kappa \varepsilon v \bar{\eta} s$ (see $\dot{v} \pi \delta t \varepsilon \sigma \iota s$ of the play), but as purposely introduced to intensify the gloom and woe of the drama. 
In this connection-viz., in disenssing the use of the old for engendering pathos of the highest kind, we may cite the Eneus. Here old Eneus-once king, but now an outcast, deprived of his empire and reduced to the necessity of tending, under an assumed name, the flocks and herds of a rustic prince -plays the leading rôle. Many of those trats of character which we have found native to the old-talkativeness (p. (60), sulfering of abuse (p. 85 ), excessive excitalility (p. 4:3), exhortation (p. 49), combined with an innate kinduess and sense of right (p. 71 ) -are the means used in this play (as in the others where the old occurj to draw ont the sympathies of the andience for Genens and to alienate even a passing pity for Agrius. Nothing could be more touching than the sight of old Geneus. formerly a king, restless and impatient under the insults with which he is continually alliticted, daily driving, in comprny with a crowd of clownish lustics, the flocks of his master to their pastme. Nor can we conceive of a more pathetic, and yet at the same time a more amusing, picture than this old man protesting that he lars not the time to enter into a conversation with the strangers, Diomedes and Sthenelus; yet led on by the talkativeness which the old could not conquer, doing that very thing and explaining at great length the humiliation he daty undergoes in being compelled, among other things, to submit to having his head used as scopus in his master's game of cottahos. The excessive excitement (Aristophanes parodies it in Acharn. 885 fr.) which the old man displars when told that one of the strimgers to whom lie is talking is no other than his own grandson, who has come to right his wrongs and to restore him his kingdom, together with his immediately lapsing into an extended series of moral reflections and exhortations, makes up a scene which for pathos and interest could with dilficulty be surpassed. Add to all this the final scenes when old Cinens-despite what he had suffered because of Agrius, yielding to that other side of senile nature, kindness, and considerateness (see page 71)-refuses to permit Diomedes to use excessive cruelty in his punishment, but forces him to be content with the exile of the wicked Agrius. All this, we may well believe, made up a dramal which merited the admiration which Aristophanes, Aristotle (Rhet. 111, 16, 
7), Plato (Ion 5.33 D.), and other's attest it received from the ancients. ${ }^{1}$

The Peleus may also be noted here. This play centers around an old man, Peleus, who has been deprived of his kingdom (by Acastus) and is now an outcast, liding in a dark and secluded cave in order to escape further indignities. He himself describes his plight in these words:

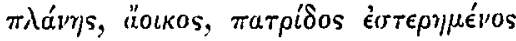

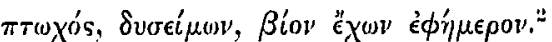

His chief occupation now is to scan with eager and restless eye the farthest horizon of the sea in search of some chance mariner who might be appronching the rocky shore. A pathetic and sorrowful figure truly! Atter a while a sailor does come, and (as in the OEneus, p. 91) the old man's excitement is overpowering" when he finds that this stranger is his own grandson. Neoptolemus. In the discussion which follows as to the best means for aronging their enemies the concejt of the old over their greater experience and consequently greater ability to give adrice is prominent. The old man chides the cmning plans of Neoptolemus and dechares that his greater experience (p. 49 ) demands that he be listened to. This trat, and the sommolency of the old (p. 32, note 1), their debility and weakness, ${ }^{4}$ tre some of the tratits of the old which the poet used to make this a jathetic and distressing play. Hartumg, Emijo. Rest., 1, 200, say's that this thagedy was "especially celchrated among the ancients."

1The outline of the play follows Hartung, Eurip. Rest.

2Frag. Dub. 38, p. 448, Matth.

"According to the scholiast, Aristophanes parodies the statement in Nub. 1153.

"Cf. Frag. Incer, 1066, which Hartung refers to this play and puts into the month of Peleus.

"In fact, it is interesting to note that Hartung usually ends his restoration of those plays of Euripides where old people play the leading or prominent rôles with some such statement. The Plisthenes is a case in point. After describing the character of Atreus in this play as "orbatus liberis, privatus conjuge, grandaevus, duplici luctu affictus, miserrimus," he almost immediately adds: "praestantiorum numero tragoediarum hoc drama habitum esse," . . . etc. (Vol. I., p. 546.) 
Cf. also the Dictys, where the presence of the old man thruout the play, with his philosophy (p. 49), with his kindly sympathy for distress (p. 71), with his irascibility (p. 43), etc., forms a play of which it is said the personages exhibit a "gravity and sublimity worthy of tragedy."

Euripides uses the old, not only for the purpose of portraying grief overwhelming and sorrow deep and profound, but also in order to enlist and hold the simpithy of the andience on whatever side he desired. We may state the proposition thus:

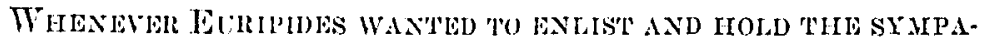

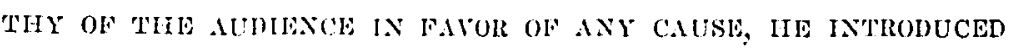

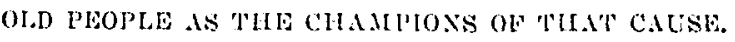

The Heraclide and the Supplices serve as excellent examples of this rule. Thus in the Heraclidie, no matter what political purpose" Enripides hatd in mind when he wrote this play, his undoubted purpose so far als the action of the play itself is concerned was to draw out an specdily as possible the sympathy of the rivacions audience for the mistreated descendants of Heracles. The andience nust esponse the cause of the Heraclids and must feel supreme aversion to Eurystheus and his cause." To accomplish this purpose Euripides builds up a play whose action revolves around a fiery old man who speaks :300 ont of the 105:5 lines of the dramal, and whose presence and feats are the topic of another one-third. The noble devotion (6-11) of this old man to his friends (a senile trait, see $P$. it) and the violence he sulfers $(75)$-the tendency to sulfere which was also a senile trait ( $p$. 35 f:.) -in their behalf first aronses in the audience the feeling of pity. This is stimulated by the frank confession of the chorus that they cannot restrain their tears of sympathy for the poor old $\operatorname{man}(127-9)$.

JHartung, Vol. I., p. 372.

eModern scholar's differ with respect to this. Hartung (Vol, I., pp. 312-13) thinks that it was intended to teach the Athenians in the time of the Peloponnesian War that a war begun in opposition to unjust demands was a pious and just war, and would be helped and favored by the gods.

"It was never intended," says Gilbert Norwood, in the Ridrle of the Bacchr (p. 21), "that the audience sympathize for a moment with Eurystheus." 
The Dramas of Euripides. ,

The feeling of pity for the weak old fellow now once aroused in the audience is skillfully wrought upon and fanued into a flame. Iolaus' speech (182-231), in which he pitiably exhibits senile excitement and garrulity, his final anxious appeal accompanied by his weird act of crowning the king as tho he were an altar, supplicatingly touching his hands and chin, his wailing request for friendship, brotherhood-aye, even for slavery; anything, all things, rather than be sent to Argosall this wolks mon the andience and is well calculated to move the heart to pity. The chor'us interprets to us this rising

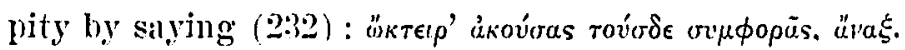

Further, his excitement at the promise of salety (lines $303 \cdot 20$; see also p. 57 fl.), his deep distress and griel (lines $427 \mathrm{ft}$; ; see also p. 57) at the sudden dashing of his hopes to the ground, his nobility in offering himself for his friends (see p. $7 \pm$ ) are some of the tratits of the old which Emipides uses to beep alive and to increase the sympatly which, as we have said, he wanted the audience to feel for lolaus and for the cause which he represents.

Euripides contrasts in the first half of the play with this poor, weak, old fellow the bold, insolent, and domineering Copreus, throwing thus the attributes of the roung out into bold relief against those of the old and producing thereby the inevitable and designed result-sympathy for the cause the old espouse, hatred and aversion for the canse the young man champions.

The poet having thus lully enlisted the sympathies of his andience on the side of Lolaus, his only duty now is to see that that sympathy does not lag, but that it is kept alive and vigorous. To do this he further uses the chalracterietics of the oldIolaus bonsting of his fidelity to his friends (see p. 74), demanding arms to fight in their behalf (681-98), his wealkness and his great desire to be young and strong (a marked senile tracit, p. $25 \mathrm{fI}$.), ete.

All these traits of character in old Iolaus make a deep impression on the andience and increase the sympathy which they already feel for him. The chorus reveals this to us, for their words (they are speaking for the audience), 


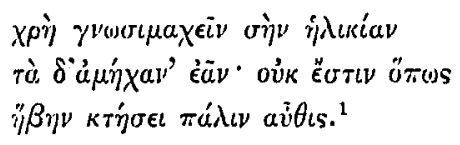

show, their sorrow at the pathetic sight.

The closing scene where Eurystheus stands before the old Alcmene, who, actuated by her deep sense of the justice of her cause (p. 75), exacts from him a full recompense for his ill treatment of her, increases the gloom of the play, and rings the curtain down upon a tragedy where the sympathy of the audience has been wholly and continuously on the side of Athens and against Argos.

The purpose of the Supplices was primarily an encomium of Athens." 'This being so, the grenter the sympathy the andience felt for the side which the Athenians esponsed and the sooner this sympathy was stimulated, the greater would be the success of the play. Consequently in this drama, as in the Heraclidar, Furipides would make use of whatever expedients he considered most efficacious to draw out the sympathy and partisanship of the andience and to present in the most farorable light the part Athens had to play. What then is the expedient he adopted? Nothing else than to identify the cause Athens should adopt with old people. and to mike the play center an'ound them till the andience shonld be fully enlisted on that side. Ethra, the mother of Thesens, the chorus, the Supplices themselves. and Adrastus, the leader of the band of suppliants, are all old people who have one and only one part to play in the development of the plot-10 enlist the sympathy

1Heracl. 706-\$.

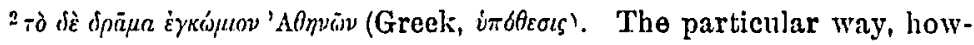
ever, in which the encomium is worked out has been stated with varying degrees of positiveness by various writers. Giles, Classical Review (Vol. IV., p. 96), thinlss the long panegyric of Adrastus ( $857 \mathrm{ff}$.) gives the cue and identifies the seven chieftains with Nicias, Lamachus, etc. Wilamowitz-Moellendorf (Heracles, p. 13) gives as his opinion: "Die Hilketiden sind erhalten in welchem der rat, frieden mit Sparta, aber anschluss an Argos zu suchen kaum minder hervorsticht

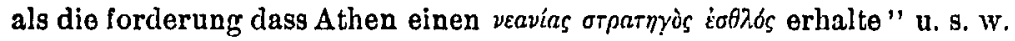
Decharme (p. 140), on the other hand, contents himself with saying: "In writing the Suppliants, Euripides has composed a patriotic work which delightfully flattered the national pride." 
of the andience in their eftort to gain the help of Athens in recovering the dead chieftains lying around the walls of Thebes.

In order to do this the wretched plight of the suppliants must so impress the andience that when Theseus at last yields, with war determined upon if need be, the wretchedness of the suppliants shall justify these heroic measures. Hence the initial scenes introduce the old, who, by their weakness and by their rery presence as much as by their words, arouse the sympathies of the audience. First, Ethra, herself a feeble old woman and well calculated to stir the audience to pity (and to admination, too, for her nolle devotion to the god in whose service she had made the onerous trip to Elensis, lines 28-30), is touched (34-5) by the pitiful sight of the old and now childless suppliants. who, falling at her knee around the altar of the god (43), beg her to intercede for them with her son (60) to help them get back their deald $(70)$.

In these earlier scenes of the play Thesens' hautenr toward the suppliants (the self-sulficiency and strength of youth over against the weakness and wretchedness of age) helps along the poct's purpose. Thesens' inflexibleness and indifference, and finally his determination to have nothing to do with them (292), his calling his mother away (286)-all bring out by contrast the ntter helplessness of these poor, bereared, childless, gray-haired mother's. The more indifferent Theseus becomes, the greater the pity felt for the suppliants. He is their only help. As he turns away we feel the despair which settles down upon the women. Our symputhy is with them. We despise the self-satisfied and self-righteous king; so that as Ethra concludes her plea with him to reconsider his decision (3:30 fl.), we are ourselves entirely won over to their cause. Any lingering suspicions that we should sympathize with Theseus in his resolution not to help is swept away. The case of the sorrowing old suppliants is our case. The words of the chorus at the close of Ethra's argument roice the sentiments of the andience: "O, dearest mine! How excellently thou hast spoken for him and for me?" (332-3.)

The poet's first purpose is accomplished. The audience sympathizes with the distressed; they are to be succored, and Athens thereby will achieve renown. All he needs to do now is 
to see to it that this pity which we feel is not suffered to grow less as the varjous incidents of the play derelop. The uncertainty and fear of the chorus while awaiting the outcome of the battle $(603 \mathrm{ff}$.), their distress as the corpses are about to be brought in (778), their antiphonal dirge sung with Adrastas ( 810 ft.), are all scenes which serve admirably to keep alive our sympathies and to render more poignant the grief we feel for them. At last, as the grandsons and aged mothers, orerwhelmed with grief, pass oft the stage bearing the ashes of their fathers and sons (1167). our conception of the miserygreat tho that misery now is-which wonld have been theirs had not Theseus interfered, is so perfect and complete that we comprehend by contrast the funl import of Thesens' intervention. We laud Athens and her king for the part they have played, and are rendy to say with Adrastus (1176-9):

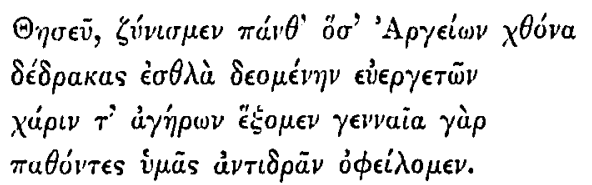

\section{EPISODE OF IPHIS AND EVADNE, SUPPLICES 990 FF.}

Since Furipides used the old to elicit the pity of the audience and to cause them to espouse any cause desired, we can understand why he introduced in the supplices the episode of Iphis and Evadne. The drama of the supplices is one where pity felt for the old is, as we have shown above. the chief expedient used to bring about the end desired, the espousal by the audience of the cause of the Supplices. Hence Euripides inserts this episole of Iphis and Eradne in order to get a cumulative effect. ${ }^{1}$ Old Iphis' lamentations about the woe of marpiage with its attendant loss of children (1187) parallels and intensifies the wish of the chorus that they had never seen the conch of man (82:2). Iphis' grief at his desolate home, bereft

${ }^{1}$ Cf. his similar use of CEdipus at the end of the Phcnissæ (1539 ff. See also p. 90). Decharme (p. 189) calls this episode of Iphis and Evadne "stirring," and speaks of it as felicitously "sustaining, by means of bold stage effect, the interest of the drama." Dr. Verrall (Four Plays of Euripides, p. 13) speaks in like vein. 
The Dramas of Euripides.

of son and daughter (1090 ft.), emphasized the desolation of the home to which the chorus is so soon to go. His excoriation of old age (1108), its worthlessness and its helplessuess, renders very dramatic and effective the utter weakness and decrepitude of the chorus as the bones of its dead are seen approaching (1115). Viewed in this light, this episode of Iphis and Evadne ceases to be an enigma, but serves, by the emphasis which it gives to the pity we feel for the old, to enhance our appreciation of Theseus' interrention in their behalf; which is but another way of saying that our admiration for Athens is increased-the object the poet set about originally to accomplish. ${ }^{1}$

The Her. Fur. gives us another good illustration of Euripides' use of the old to enlist the sympathies of the andience in a certain cause. During the first part of the play the action center's around the delivery of suppliants from death. These suppliants must naturally therefore win our sympathy. As we should expect, so we find them grouped around an old man, Amphitryon" (supported by a chorus of old men), who remains the central figure of the drama until the need of the play is attained and the audience supports his cause and withdraws all trace of sympathy from Lycus. This result is attained in the usual way. Old Amplitryon is decrepit and nseless, so useless as not to know, so he says, whether he is still to be called a man (41), fleeing for his life and acting as the protector (45) of a def'enseless woman and her children ( $17 \mathrm{ft}$.$) ,$ in need of all things-food, drink, clothes, and even a bed (51-2) -and utterly friendless (53). Furthermore, the chorus, as it files in $(107)$ on halting step (10S; 119), deprecating their flown power and strength (111), intensifies our feeling of depression and pity. All play their part well, for we esponse their cause from the first and loathe $I_{1 y c u s}$ and his

1See footnote 2, p. 95 .

sLallier (De la Condition de la Femme, p. 211) says of this whole scene: "Il y a une alliance touchante entre la faiblesse de la femme et celle du vieillard." Euripides is fond of such scenes. Besides the ones already noted cf. the Dictys, where Dictys crouches with Danae at the altar of Zeus Herceus, and the Cressæ, where the old messenger, Thyestes, and the boys flee to the altar to escape Atreus. 
Dramatic Characteristics of the Old.

haughty, high-handed methods. The sympathy of the audientes

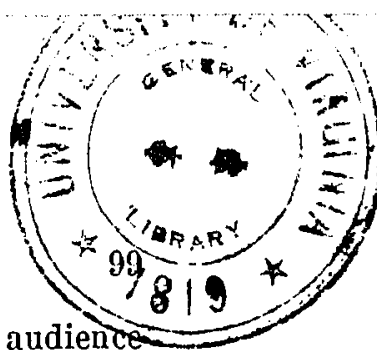
thus acquired is greatly strengthened as the old fellow shows to us those well-defined senile traits of character which we lave seen (pp. 1 to 79 ) the old possess-excitement, love of children (170-189, shown in his desire to defend Hercules from the charge of cowardice), keen sense of justice (217-25), ardent desire for youth (228-35; 268-9), the suffering of abuse (238. 251), etc. Moreover the vigor of the old chorus (252) in refusing to be intimidated by the menaces of the usurper elicits our applause and sympathy. Furthermore Megara's lengthy discussion (287-311) addressed to Amphitryon keeps the litter before us, identifies her fate with his, and keeps alive within us the pity we feel for their misfortunes. The climax is reached, however, when, after Megal"a has said farewell to her children, the old man himself gartulously and pathetically bids (p. 58) his friend and the chorus good-by.

At this point, when our pity for the plight of the suppliants is at its height, when we hate Lycus intently and feel that any punishment which might come upon him would be richly deserved-a state of mind to which we have been brought by the skillful use of the old-Hercules arrives, saves the suppliants, kills the usurper, and makes the clénouement of the first part accord with the state of mind the poet has created within us.

The second half of the play, which is more or less loosely connected with the first hall, ${ }^{1}$ has for its possible object the glorification of Athens. Tho Hercules is the central figure here, and tho he is already in the good graces of the audience because of the action of the first part, yet we are never permitted to lose sight of the fact that he is the son of Amplit. ryon and that his distress (and his cause) is that also of the

IDecharme (p. 226) thinks the disjointed nature of the play is one of appearances only; for "in spite of appearances," he says, "there does exist in this tragedy a unity of high order." This unity is . . . "Hercules, . . . the mighty figure . . that dominates the whole play." Patin (Vol. 3, p. 208) took this position fifty years before Decharme. He says the tragedy consists "des faits indépendants l'un et l'autre, mais que le poëte, qui les rapproche, ramène, par le contraste même, a l'unite." Wilamowitz-Moellendorfi' (Her., Vol. I., p. 343) thinks, on the other hand, that the drama is a subjective expression of Euripides' mentivity. 
old man, Amphitryon. For there is always some reference ever and again made to him and Megara (903, 963, 1002, 1011, 1165 , etc.) ; or he is himself introduced upon the stage to carry on the dismal lamentations for the sorrows which had come upon him (1039-41 ff.), or to evince tonching solicitnde and anxiety for his son (1042 ff., 1072-7, 1111-45, etc.).

By these means the poet is aided in sustaining the sympathy which the audience has felt for Hercules from his first entrance upon the stage. At the end of the play Hercules details to Amphitryon the duty of burying the dead children. ${ }^{1}$ So that the play actually closes with our sympathies rather with the old man than with Hercules, for the latter goes saved to Athens, whereas the old man is enjoined to live in Thebes, which is conceded to be a difficult and sad fate (1365). And the curtain falls upon the lone old man doomed to sad duties (1420) and to solitude mubroken, at least for a time.

That the old are used by Euripides to gain or maintain the sympathy of the audience for a certain cause is seen again in the Andromache. Andromache, now the slave of Neoptolemus, hated and hounded by Hel'mione, has hidden her son, Molossus, and taken refuge herself at the altar of Thetis. She is, however, persuaded by craft and deceit to leave the altar, and she and her son, whose hiding place has been discorered, are thus wholly in the fower of the revengeful Hermione (and Menelaus). Just as they are being led away to death and just as we feel that there must he some speedy help if a great calamity is to he averted, old I'elens comes panting and pulfing in (546) to espouse their cause and to save them. The entrance npon the stage of Peleus, with his senile attributes of lopuacity, excitability, pretended strength, almonitions, and philosophy, adds pathos to the play and intensifies our partisan senti. ments. The old man's tottering jresence, his grief, his reference to bimself (614) as one of the disconsolate fathers whom the Trojan War has left desolate make the scene one of overwhelming pathos and deepen the pity we have previously felt for Andromache's position. When the old man leaves the

1Cf. this scene with the strilingly similar one in the Tro., where Hecuba is left to bury Astyanax (p. 88).

nFor all these personal traits, see page $24 \mathrm{ff}$. 
stage, our feeling for him and for Andromache is one of real distress. The mexpected turn of allairs by the arrival of Thetis and her promise of immortality to Peleus (1253-6) bring us a feeling of actual relief. Her exhortation to him,

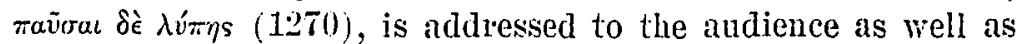
to him.

The ending of the Andromache reminds us of the Alcmene, in which play Euripides makes his usual use of the old either to portray deep pathos or to arouse the sympathies of the andience for a given cause. In this play the senile traits of close friendship for friends (p. 74 , note $3 ;$ p. 72 , note 1 ), of weakness (1). 28), love of peace (p. 73), etc., are finely contristed with the rashness and venturesomeness of youth. Old Alcmene and licymnius, than whom no more interesting characters are foumd anywhere in our poet, by their mildness and mutual kindness completely win the sympathy of the audience for their: cause, which we feel (in spite of Tlepolemus) is that also of the Helaclids; so that when the murder of Licymnius is reported and Thlepolemus is put on trial for his life, we feel little, if any, smmpathy for him in the distressing situation in which he finds himself (Frag. (is). We rather rejoice at the sentence of exile which is pronounced against lim, and the pathetic words,

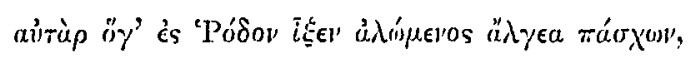

and his subsequent shipwreck altect us but little.

On the other hand, the dying Alcmene, overwhelmed with sorrow, deprived of her loving and beloved brother, touches us profoundly. We welcome her translation to the Elysian Fields and to the bosom of Rhadamanthus as a well-merited reward after her great suffering.

In the Ion we see clearly again the use Euripides made of the old in his dramas. The first 700 lines of the play have introduced us to the characters of the drama. Xuthus and his wife, Creusa, have come to the oracle to ask the god for children, to share the same blessed promise or to endure the same disappointment. Now, however, quite unexpectedly $\mathrm{Xu}$ thus has received a son whom he thinks it best, for the sake of prudence, to introduce into Athens under an assumed name 
(654-67), intending to seize a farorable opportunity (should one present itself) to break to his trusting wife the fatal news that Ton is his son and heir by a former illicit love (659, 54555). He charges the chorus on pain of death to breathe no word of this to his wife (666-7). They, however, make up their minds to tell Creusa the entire story (694-712) of Xuthus' and Ion's fathership and sonship and of her excessive wretchedness. It is at this juncture when Creusa is to become the central personage of the play, and when it is desired that all our sympathies be swung, at least for a time, entirely from Xuthus and from Ion to Creusa and her wrong, that the tottering old servant of the now deceased Erectheus comes Lobbling on the stage as the close ally and ardent supporter of her from whom is so soon to be wrung those exquisitely disconsolate lines (8659). The old man's weakness (739, 745), his sympathy with Crensa's plight, his words of comfort (76T) when she hears the crushing news, his fertility in plans, and his stanch adrocacy of her canse (986, $970-8,1020$, etc.) effect the usual result. Xuthus and Ion, whom we once admired, are put under the bau, so to speak, and Creusa has oui whole sympatby. The old man here, as in other plays, fulfills his dramatic purpose and causes us to mike his cause onr cause.

In the Orestes we see again the dramatic purpose of the old. Because of the touching scenes ${ }^{1}$ of the first 470 lines-the sisterly affection and solicitude of Electra for Orestes-we are jnclined to forget Orestes' heinous guilt of matricide and to give him our unrestricted sympatly in his deep afliction. Orestes, however, is an outcast (430), hated by the gods (531), a murderer, and it is not the poet's purpose that we should sjmpathize with him too much. It is at this juncture that Tyndareus, a venerable man (548), is introduced, led and supported by his attendants. His venerable aspect itself commands our attention, and we wonder what side he will espouse.

\footnotetext{
1And yet Patin (Vol. III., p. 43) finds in these opening scenes (note that young characters only play the rôles) so much that is reprehen. sible that he asks: "Ne détournent-elles pas le spectateur des émotions véritables du drame, de celles qu'il avait déja fait naitre et qu'il promettait?"
} 
It is not too much to say that we firmly believe that he has come to help Orestes (so strongly are our sympathies with him), and we are surprised to find the trend of 'Tyndareus' remarks to be against Orestes. At first we are unsympathetic with the stand Tyndareus has taken. It is not long, however, before his words command our closest attention. His stanch advocacy of law (512-36), his conception of the fundamental principles in the case (523), and the direful effects of illegal acts (5:4-5), even if they are animated by a kindly feeling of kinship (486), convince us that our first impulse toward unrestricted sympathy with Orestes is wrong, and that, tho Orestes is unfortunate and in so far as that goes worthy of our sympathy, yet the strict justice of the case demands that we put ourselves on the side of Tyndinens. Clytemmestril really deserved death; yet Orestes, her son, was not the proper instrument of punishment (588-9). It is in this as in other plays: The dramatic purpose of the old is to guide and deepen the sympathies of the audience. Then those srmputhies are going wrong, as here, the introduction of an old character, displaying some if not all the traits of the old, turns them from the wrong into the right channel. Menelaus, at any rate, tho at first an ardent chimpion of Orestes ( $48 \%$, etc.), when once set right by Tyndareus, maintains his position throot; so that at the very end of the play, even when threatened by Orestes with the death of his danghter, Hermione (1609)), unless be persuades the Argives to grant him lis life (1611), lhe reluses to intercede for hin, but urges instead the $\mathrm{Argives}$ to rise against the matri. cide who is seekiug to force them to ignore law and right (16214). If Apollo had not intervened to clear himself and to arrest the judgment, the doom of Orestes would have met (solely because of Tyndarens' attitude) with our approval. Te justify his escape from punishment only because of the fact that it was the evident will of heaven.

In the satyric drama, the Cyclops, is seen the same expedient -the old-to provole the sympathies of the audience. It is not necessary for us to decide whether the object of satyric

1Patin (Vol. III.) speaks with respect to Tyndareus of la colère et la redite de la vieillesse (see p. 44). 
plays was, as Paley maintains, ${ }^{1}$ antiquarian-that is, to retain "in the best days of the Athenian stage types of the true ancient rpvyodia, the rintage song out of which the dithyrambic element of tragedy was dereloped" -or whether it was, as Horace says simply to give amusement. The main point for us is that Euripides wanted to provoke as quickly as possible (satyric plitys were short) the emotions of his audience, whether those emotions were serio-sympathetic (Paley) or comicosympathetic (Horace), and he does this here as in his other pliys by introducing an old man, silenus, and making him, with the weakness and toibles of old age, the leading character. Thruout the play he skillfully uses this old man and his aged characteristics to further the ends of the drama. The old fellow's desire to appear courageons, his natural timidity (see p. 31), his quirle wit in finding excuses, and the fumy scene in lines byto-s) (see p. (6.t If.) alle all tonches tending to draw out our serio or comico spmpathy. I'ossibly, however, the two traits of the ohl which are used with most telling effect in this play are:

(a) Their religiosity-i. c., their nittural and abiding belief in the gods, and their persistency in calling upon them.

(7) Their amusing fertility in derising ways and means to extricate themselves from embarrassing predicaments.

As we pointed out on page !, in the mouth of no other than an old charater would Silenus' oath $(262-\tau)$ be half so comic or pathetic, nor would those monstrous lies (232-40) and the comic antics (5-40-89), if assigned to any other actor, be nearly so effective. We laugh at the old fellow, yet there is not lacking

1Vol. III., p. 553, of his Euripides.

2A. P. 220-4. Patin (Vol. III., p. 446) sides with Horace, and says satyric dramas were "destinés . . . uniquement à amuser, a égayer l'esprit." A little later on he says: "Les catastrophes funestres, sanglantes même échappaient au pathétique, à la pitié, n'excitaient que des ris." Also Nauci (Vol. III., p. 66), quoting Diomedes, says: "Latina Atellana a Graeca satyrica differt, quod in satyrica fere satyrorum personae inducuntur aut si quae sunt ridiculae similes satyris, Autolycus, Busilis." 
a decided feeling of pity at his present degraded and humiliating position in the service of the Cyclops. ${ }^{1}$

In the Baccha, since the purpose of the play is, in the light of modern criticism, so in doubt; $;$ it is diflicult to aftirm with definiteness just what cause the poet intended the audience finally to espouse. This much, however, may be said: "In the Bacchx, as sometimes elsewhere, the poet has made his characters plead two contradictory canses-that of mysticism and that of reason. It is the cause of mysticism which is developed at greater length and with greater force." It is obvious, therefore, that the poet would want his audience, at first at any rate, to espouse the cause of mysticism" inasmuch as he developed that cause at a "greater length and with greater force." In other words, he wants the audience, at first at any rate, to espouse the canse of Dionysus," and he sets abont to effect his purpose in the usual way. He introduces two old men, Tiresias and Cadmus, full of dignity, pious devotion, and venerableness, yet withal exhibiting the frailties of the aged: loquateity, helplessness (364-5, 198, 211), shrewdness (333), timidity (337

1.Patin, remarking along this line, says (p. 465): "C'est merveille de voir . . comme s'entrelacent habilement, dans cette petite pièce, les émotions diverses de la comédie et de la tragédie."

" doubts and reservations; naturally, for wherever we turn we seem to see arguments on both sides placed in perplexing proximity. On the one hand we have the supposition [supported by Naegelsbach, Paley, Pohle, Weclilein, Bernhardy, K. D. Nueller, Berlage, and Gomperz] that the poet is frankly going back on the opinions of a lifetime and is recanting in favor of the popular faith; on the other, the theory [supported by Roux, Patin, Brumn, and Decharme] that the Bacchre is a polemic against that faith." (Gilbert Norwood, in The Riddle of the Bacchr, p. s1.)

Decharme, p. 64.

If Euripides desires, as has been maintained (Norwood, Riddle of the Baccha), to vilify Dionysus and to make Pentheus the hero of the play, he took a very roundabout and doubtful way to accomplish his purpose. Mr. Norwood, who advocates this view himself, says: "We need not assume that the audience could understand . . . the Bacchæ . . . at one sitting" (Riddle of the Bacchæ, p. 131).

"Gilbert Murray, in his introductory essay (p. liv.) to his translation of some of the plays of Euripides, boldly declares: "The sympathies of the audience are with Dionysus while he is being persecuted." 
fi.) - traits which, when combined with the nobler ones mentioned above, are especially adapted, as we have shown, to work upon the emotions of the audience. These two old men serve in excellent wise their purpose of enlisting the sympathies of the audience for the cause which they represent and of showing up the hauteur of Penthens. Our sense of propriety and fitness is rndely jarred by the young ${ }^{1}$ king's ronghness and coarseness (343-6), by his pettiness (346-51), and by his brutality (352-7), so that we are quite ready to echo the sentiments of the chorus in their ode on chastity of speech and life (370-430).

The old men have served their purpose. From now on we seldom, if ever, waver" in our feeling that such a character as Pentheus has shown limself to be must erentually meet with a terrible fate. Our sympathies at this juncture of the play are completely alienated from Pentlieus and centered upon the cause of Cadmus and liresias.

Another interesting use of the old is seen in the apparently chance reference to Cadmus by the messenger in lines 1025-8. The story the messenger has to tell is one of horror and con. cerns Pentheus entirely. The whirling scenes thru which we have heen hurried since Tiresias and Cadmus were last on the stage have tended possibly to lessen our sympathy for the cause of the old men. We may be inclined even to pity Pentheus for his present plight. In order, however, that by no possible chance our sympathies may be awakened for the horrible fate of Pentheus, our minds are made to revert, by the messenger's reference, to Cadmus and his sorrow (1024-8), to those preceding scenes (170-431) where the nobility and wenkness inherent in the old men had entirely enlisted our sympathies. The words of the messenger touch the chord of our emotions and set them vibrating once more. We are in no danger now of feeling pity for Pentheus, no matter what the messenger may say his doom

1Cf. lines 1184-7.

II feel that this is true, the new theory of the Bacchr to the contrary notwithstanding. Wecklein, quoted by Norwood (Riddle of the Bacchæ, p. 63), voices, I am sure, the feeling of the majority of readers and students when he says of Pentheus: "Er ist ein kalter Verstandesmensch und seichtes Freigeist, ein gottloser Rationalist, ein Erdgeborner u. s. w." 
has been. The old men have thus again plajed their rôle of gaining and holding our sympatbies for the cause they represent.

Also later, when we are overcome by the picture of distress and utter helplessness which Cadmus brings before us by his words (1302-24) on the defenselessness of his old age, now that Pentheus is dead, and when we are liable possibly to forget, because of his former lindness to Cadmus, Pentheus' sacrilege and to pity his fate, we are recalled to a true view of the situation by the words of the chorus (1328-9): "It is for thee, $O$ Cadmus, that we grieve. This fellow has met a worthy fate. For thee we grieve; we grieve for thee."

Also in the closing scenes of the drama the same use is made of the old. The exile of Cadmus, which is worse than death itself (1352-60), his overwhelming solrow for his children (1372), and his own firm trust in the god in spite of what he has suftered render more dramatic and lorceful Agave's repudiation of the Bacchic rites (1981-7) ; so that if the poet's purpose in this part of the play was in reality to condemn the Bacchic religion-at least in part ${ }^{1}$ - the mresence of the old man with his afliction and his weakness helped, as the presence of the old always did, the poet to accomplish his object; for the present and evident distress of her father-the result of the same jnfluence which caused Agave to murder her son-would go far to justify in the minds of the audience Agave's harsh and hitter repudiation of the Bachic worship. If, on the other hand, Euripides' object was to praise ${ }^{2}$ Dionysus and his rites, the presence of the old man with his implicit and abiding faith (1326-7, 1249-50), unshinken by the dire calamities which have befallen him, would accomplish his purpose in the best possible way.

In the Alcestis old Plieres plays the usual senile part. A selfish old man himself, he brings out the still greater selfishness of Admetus. The scene beginning with line 614 between the two crystallizes the rising animosity ${ }^{3}$ which the audience has felt for Admetus and which has been kept from crystallizing

1Norwood, Riddle of the Bacchæ, p. 120.

2So Dr. Kraus in his work, Euripides, ein Bekehrter Rationalist?

3Cf. 197, 240-3, 210. 
before only by the hospitality (faltering and hesitating to be sure, but hospitality notwithstanding) which he displays to. ward Hercules. Thus the nobility of Alcestis, one of the things, possibly the chief thing, the poet had in mind to portray by the play, is greatly enhanced by contrast with the manifest selfishness and meanness of the man and his family ${ }^{1}$ for whom she is dying. The poet is thus seen again to use the old to bring out those phases of his drana which he desires to emphasize and which he wants the audience to sympathize with. In fact, so important is the function of old Pheres along this line that at least one writer thinks that the scene in which he performs for the first time discloses beyond peradrenture the poet's purpose in the play. ${ }^{2}$

The principles stated on pige 85 and on page 93-viz., that Euripides used the old (a) to engender a feeling of deep pity in lis andience, and $(b)$ to enlist their sympathies in behall of any cause-are well illustrated negatively by a study of those plays such as Ilelen, the Nedea, the IBlectra," the Rliesus,

1Along this line Patin says (Vol. III., p. 15): "Une des choses qu" Euripicle s'est le plus attachè à faire ressortir dans sa plèce, c'est le contraste du dévouement d'Alceste, avec l'insensibilité des parents d'Admète, qui, si près de la morte, n'ont pas voulu mourir pour leur fils."

"Dr. Verrall, Euripides: The Rationalist, p. 59. To be sure, Dr. Ver. rall does not think the nobility of Alcestis nor yet the selfishness of Admetus the chief purpose of the play. He grants tho that they are strong secondary objects (p. 111). "The Defeat of Death" (p. 113) is the molal for which he is contending, and he boldly avers (p. 120) that the Alcestis as a whole is a "flawless masterpiece of wit."

sDecharme says of the Electra (p. 241): "It is one of the poorest of his extant plays." And Patin (VoI. II., p. 2a1) says: "Le jugement des critiques qui s'en sont occupés, . . . la présente, malgré le mérite des details et du style, comme une des plus imparfaites productions de son auteur:" The Orestes is likewise criticized, even being assigned to the rank of a satyr play, Prinz (quoted by Decharme, p. 258). This is due, however, to the unfortunate ending of which Patin speaks in no uncertain terms (Vol, III., p. 64): "Ici (1048) s'arretent les merites de cette tragédie, commencée avec gênie, mais bien médiocrement terminee." Again (p. 65): "En vain Euripide cherche à relever ce qui n'a aucune grandeur:" It is interesting to note that for all those parts of the drama which lead up to or describe the appearance of Tyndareus, Patin has nothing but praise, unconsciously emphasizing thereby our thesis that the old lend interest and direction to a play. (See pp. 102-3.) 
the Taurian Iphigenia, ${ }^{1}$ and even the Alcestis, where the old have only a subordinate part to play and where their appearance on the stage is reduced to a minimum. In none of these plays do we find the intense pathos ${ }^{2}$ and heart-rending distress which we find in those plays where old people are the chief actors-e. g., in the Troades, Supplices, Phœnissæ, etc. In fact, with respect to some of them, the Helen, ${ }^{3}$ for example, it is hardly too much to say that, as we read, the emotion we feel is more like that which comedy (not tragedy) excites. Now and then, however, there is found a scene in these dramas when an old man or woman becomes the leading character for the time. Such a scene is always affecting, and moves the heart of the audience to a feeling of compassion and draws out their sympathy for that particular phase of the action which the old character happens to represent. A case ${ }^{+}$in point is found in

tWeil (Sept Tras., p. 438) say's of the I. T.: "Toute fois il (le spectateur) prevoit au fond que tout s'eclaircira, il sait que le poëte se joue a la fois de ses personnages et de son public, il prend plaisir a voir le dénonement inévitalsle tant de fois imminent, et tant de fois éludê, il jouit enfin délicieusemente d'une émotion qui n'a rien de violent, rien de sérieux, et qui n'en est pas moins réele . . . Le poëte plus tragique n'y a jas fait usage de toute sa force."

"Of course it is not denied that some of these dramas contain some very effective scenes-the sacrifice of Iphigenia, for example, in the I. A.; the recomnition scene in the I. T., etc. There are interest and excitement in these scenes, but little, if any, excessive lathos.

"'The almost total lack of tragic grimness in this play has induced Dr. Verrall to regard the whole as an intentional burlesque," says Gilbert Norwood, in The Riddle of the Bacchæ (p. 149). And Dr. Verrall himself says: "The pathos (of this play) smiles, . . . and of horror or of tragic pity not the faintest trace whatever. The whole piece imitates comedy closely." (Four Plays of Euripides, p. 88. So also Decharme, p. 248.)

"Cf. also the scene in the Alcestis between Pheres and Admetus, $p$. 107. The scene in the Andromache where Peleus performs might also be cited here. For tho this scene does draw out our sympathies for Andromache and her cause thruout the play (see p. 100), it probably is better considered-in view of the aclinowledged "episodic" nature of the play-as itself an episode. In this connection note again the episode of Iphis and Evadne in the Supplices (see p. 97). The scene in the Electra, when the old man brings the provision for the entertainment of the strangers and subsequently recognizes Orestes, might also be compared here. The old fellow's kindness, weakness, 
the Medea. The events of this play as they come before us cast but little real gloom upon us; and certainly no feeling of intense sorrow, no heart-rending sympathy for the actors, is awakened within us. We feel anger and resentment at Jason, a sense of justice at Medea's revenge, but no great pity ${ }^{1}$ or overwhelming grief." Toward the end of the play, however, in the speech of the messenger (1136-1230) the mention of the old father of Creusa and the description of his lamentations at the death of his danghter (1209-10), his desire to die with her, his frantic but futile efforts to tear himself a way from the tenacious clutch of the medicated Hesh (1211-14), his gradually weakening efforts, and at last his death greatly increase the gloom and

shrewdness, etc., add great interest to this particular scene. The scene in the Cresphontes where the old internuntius prevents Merope from slaying her son might also be cited. The whole theater was in intense excitement lest the old man, who, for the moment, becomes the pivot of the action, should be, because of his slow movements, too late to arrest the blow. (See Plutarch T., 11, 998, E.) And Aristotle praises the scene as especially fine (Poet., c. 14, 9). Another illustration may be taken from the Antiope. The activity of the old pedagogue in the latter part of the play, his pity for Antiope (See p. 71), and his final rescue of her, by his good advice, from death made a very impressive ending of the play and contributed undoubtedly no little to the celebrity of this play in antiquity. Propertius, Pacuvius, Holace, Virgil, Ovid, Cicero, Plato all admired the play excessively, quoted from it, or copied it. It even gave a proverb to the language. Cf. Hartung, Vol. II., p. 429. The Protesilaus also may be cited. The excitement of old Acastus when he thinks that his old age is to be spent in solitude, deprived of his daughter, his argument with Protesilaus, his solicitude for his daughter, and his final lamentations for her untimely death and for his own solitude, all go far to overshadow the central fact of the play-the touching devotion of Protesilaus and Laodamia for each other.

1So Thomas Miller (Euripides Rhetoricus, p. 71): "Hominem (Jasonem) non miseramur: potius aspernamur."

2A partial exception to this statement might be made in favor of the prologue. The first Greek argument says:

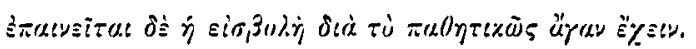

It is interesting to note that the old nur'se and the old pedagogue are the personages of this part. Even if the praise referred to has relation to the structure and content of the prologue, it may well be that the appearance of these old people on the stage was largely-even tho unrecognized at the time-instrumental in evoling it. 


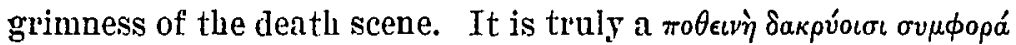
(1221), made more so, as the narrative implies, because the old man also suffers (1220-1) :

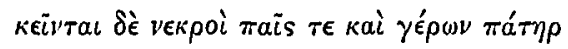

$\pi \hat{\lambda} \lambda$ s.

\section{EXCURSUS ON THE TIME IMIJIED IN TO THPAS.}

In the preceding discussion on the traits of the old I have made use of those characters only to which Euripides himself applies some of the following terms : ${ }^{1} \pi \rho \in \epsilon \beta u s$ (and its deriva-

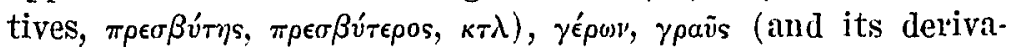

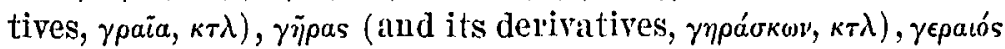
or ynpaiós, madaiós, etc. Tho there are (a few) others of his characters who, because of their marled senile traits"-loquacity, etc.-were eridently intended by Euripides to be (and they were) represented upon the stage as old people, yet, because they do not happen to be specifically denominated ly any one of the alove words. I have not ventured-tho fully persuaded in my own mind that they are old people-to use them as examples in my discussion of the old.

With respect to the various terms for "old" above mentioned, it is interesting to observe that Euripides used them apparently without any discriminating sense as to their finer shades of

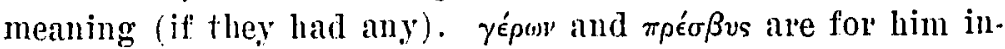
terchangeable and virtually equivalent. He did not seem to discriminate between the words, tho Ammonius," quoting ${ }^{4}$ dris-

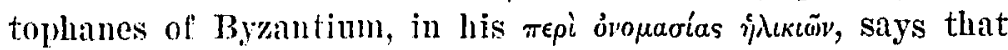

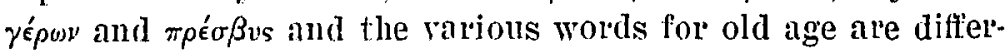

The only exceptions are Adrastus in the Supplices (and he is called $\left.\pi \sigma \lambda_{c} \sigma c\right)$ and the Aepúnov in the Hippolytus. This latter by implication plainly calls himself a $\gamma$ f́fov (cf. line 114). A further exception should be made, perhaps, in the case of the fragments. Where I have used the plot of the lost dramas, I have followed Hartung and have used his "senes."

2The Phrygian slave in the Orestes (1368 ff.), for example. In fact, Paley and other commentators speak of him as old.

:De Differentia Vocabulorum, p. 36 (Valckenaer).

-TaIckenaer ad Ammon., Vol. I., Chap. XIr., Sec. 50. 
ent. ${ }^{1}$ For Euripides, however, as I have said, $\gamma \in \dot{\epsilon} \rho \omega \nu$ and $\pi \rho \epsilon \sigma \beta \nu$ s are the same. For example, in the Ion, Creusa calls the peda-

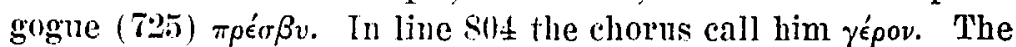
same ter'm is used in 994,9967 , and 999. In 1171, 1211, and 1214, however, the old man is called $\pi \rho \epsilon \sigma \beta v$. In the I. A.. Agantemnon

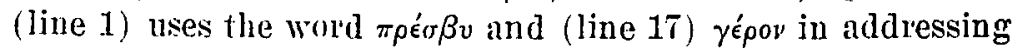
the same old man.

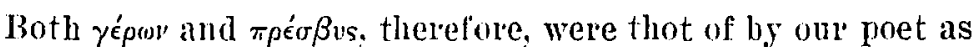
being that period of life which the Greeks called by the general term rijpas. The question which now naturally follows is: At what time did a man or a woman enter the period of life called $\gamma$ jipas? In other words, when did $\gamma \bar{\eta}$ pas begin?

The etymology of $\gamma$ inpas is given ${ }^{2}$ as twofold:

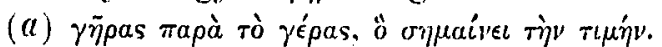

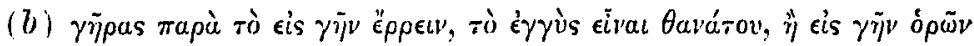
каi $\beta \lambda \epsilon^{\prime} \pi \omega \nu^{3}{ }^{3}$

Etymologically, therefore, old age was incipient either,

(a.) When one achieves renown and is heralded as "great," or

(b) When one's physical forces begin to fail.

Now, either of these two circumstances will occur to different men at different times. One man will become great, in fact so great as to be the conquerer of the world, before he is much past 30, while another will achieve much less renown in three times that length of time. Again, one man will become enfeebled-by his excesses or by natural causes-much sooner than another. The time, exact time, when old age may be said to begin becomes, therefore, a diflicult matter to fix. And this difficulty the ancients themselves felt very keenly, for when trying to define the initial period of old age, they range all the way from $85^{4}$ to $70, \bar{n}$ and even then they are not certain of their conclusions.

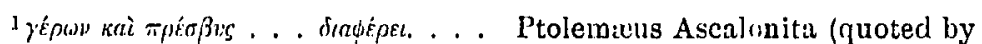
Fabricius, Vol. VI., p. 162, Harles' Edition) uses exactly the same words. "Sturgius Etymologicum Graecae Linguae.

sof course it is well understood that these etymologies have no scientific value for modern critical scholarship. They are used here merely to enable us to arrive at the conception which the Greeks had of the word $\gamma \tilde{\eta}$ pas.

4.Julius Pollux, Onomasticon, Book II., 1, 4.

"Aristotle, Polit., Vol. VII., 16, 3. The Greek of these two passages is found on the following pages. 
An interesting illustration of this uncertainty occurs in

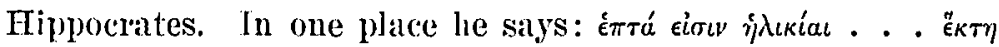

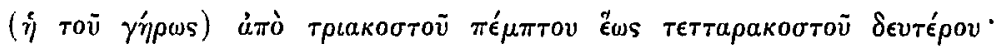

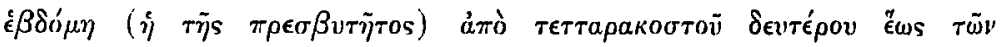

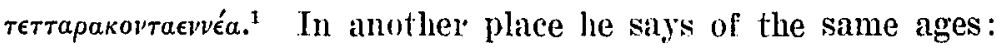

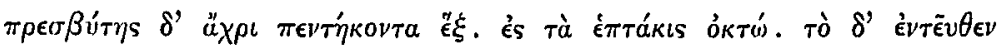

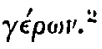

In the first quotation $\gamma \tilde{\eta}$ pas begins at 35 and precedes $\pi \rho \in \sigma \cdot$ $\beta v \tau$ 's, which begins at 42 and extends to 49 , whereas in the latter passage $\pi p \epsilon \sigma \beta v \tau^{\prime}$ s $^{\circ}$ extends to 56 , at which time $\gamma \tilde{\eta} \rho a s$ begins. Philo, however (basing his argument on Solon Frag. 27, which he quotes entire), seems inclined to push the period of $\gamma \tilde{\eta}$ pus still further forward than $5(i$. He sily's that there are ren periods of seven years each in a man's life. After describ.

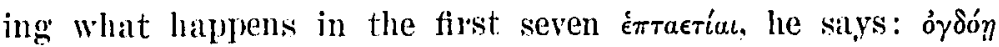

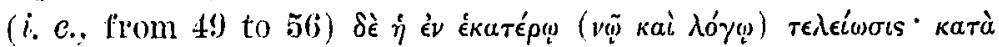

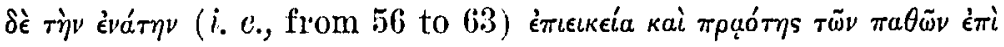

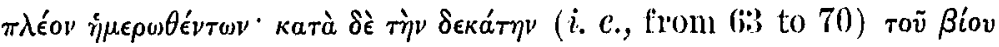

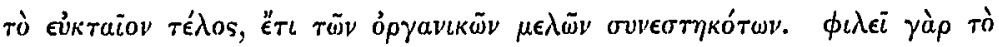

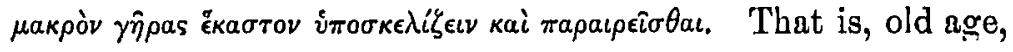
if it is based upon weakness (and Philo obviously so based it), begins about ( 65 or) 71 ). This corresponds closely to Aristotle's conception. For in speaking of the power of procrea-

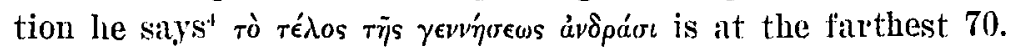
And Plato had the same idea, for he says that up to 55 a man

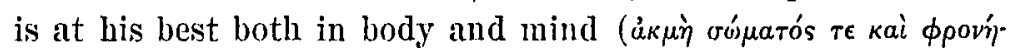
$\sigma \epsilon \omega s)$, so that old age would not begin for 10 or 15 years from that time.

Old age was, however, to the Greeks, not so much a time as a condition-a fact more or less clearly implied on page 112 in the etymology of rijpas. Pollux" clearly shows this

${ }^{1}$ Quoted by Julius Pollux, Onomasticon, Book II., 1, 4.

2Quoted by Philo Judaeus, De Oríficio Mundi, Sec. 36, M.

:De Orificio Mundi, Sec. 35, M.

4 Polit., VII., 16, 3.

-Repub., Book V., 460.

onomasticon, Book II., 11, 21. 


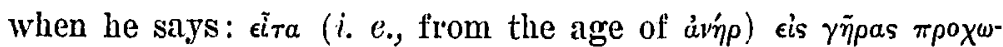

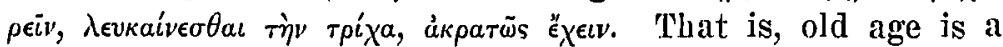
time of whitened locks and weakened bodies (not necessarily weak bodies); and since Greek tendencies were strongly conservative with respect to entrusting responsible positions to younger men, the two etymologies given above-that from $\gamma$ ćpas and that from eis $\gamma \tilde{\eta} \nu$ "epetr-virtually converged into the following formula :

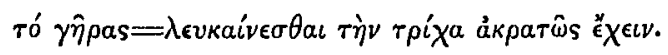

And this is the conception-vi\%, that old age is a state rather than a time-which Furiprides had; furthermore he acted unon this conception. For when a person exhibited such and such traits of character, he belonged to such and such a class, no matter what his age. Thus Theseus in the Fippolytus is a yéposy in the estimation of Surpipides, tho he does not call him so in so many works. ${ }^{1}$ He undombtedly was so represented upon the stage.

Frowever, if we prefer figmes, since white hatr and weakened hodies are not likely (tho they are, to be sure, possible) ${ }^{2}$ in the ordinaly conrse of nature to appear before 65 or 70 , we can (if we will) fix these points of time as in a general way mark-

1 Theseus exhibits among other traits these well-defined ones: $(a)$ Religiosity. When we first hear of him he is off on a fecopia (281. Cf. 806 , etc.). He turns instinctively to the gods for help in his vengeance ( 887 ff.). (b) Excitability. This is shown in the scene with his son and in the kinurata ab initio (811 $\mathrm{Mr}$.). Note also the repetition $877,879,830$, etc.). (c) Fondness of gnomic utterance $(916-20, .925-30$, 936 ff.).

2This possibility is the justification (I suppose) which Hippocrates (see p. 113) had for fixing the time when a man was a $\gamma \dot{f}$ foun at from 35 to 42. C. F. Hermann (Archiv fuer Philologie und Paedagogils, XII. [1840], p. 327) argues, bowever, that $\pi \rho \varepsilon \sigma \beta u \pi / s$ began before 57 , and quotes Cicero ad Att. VI., 6: "Wo dieser im J. 50 a Chr., als el noch nicht 57 Jahre zaehlt, von dem Entschlusse, statt seines Bruders seinem Quaestor Coelius den Oberbefehl in der Provinz zu hinterlassen schreibt: hoc melius et huius rei plura exempla, senectuti quidem nostrae profecto aptius." It is to be noted, however, that Hermann

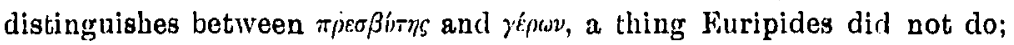
for Hermann says, quoting Philo (see note 2, p. 113):

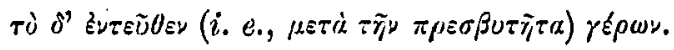


ing the terminus post quem, so to speak, of the old in Euripides. ${ }^{1}$

This much for men. For women the following: They matmed earlier. Platon marries them at from 16 to 20 , and men at from 30 to $: 3$. Aristotle declares that the farthest limit of fermulity is 50. Immediately thereafter (the cessation of fecundity), if not somewhat earlier, we would expect the dvкaivertal rìv rpixa period. For a woman, therefore, we

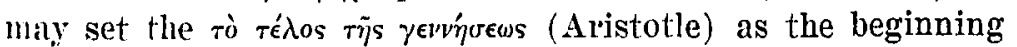
of yĩpas. And this P'aley does; for he siys : "By $\gamma \tilde{\eta}$ pas, applied to women, the Greeks only meant the age when she ceased to bear children." That is, yijpas for a woman, generally speaking, legan about 5is or 60 .

In conclusion we must consider the old of Euripides' stage is varying between the age of 55 (for women) and (65 (for men) and the ntmost limits of the érxaroy yijpas of the lexicographers. fime-for ex:muple, dolrastus in the Supplices-are but beginning the period of ripas; while others-for example, Hellen in the Irominfe-lave alvanced far along the road.

IWilamowitz-Moellendorff, in his Heracles (p. 343, Vol. I.), says: "Man kann das rijnas vor clem sechzigsten Jahre unmoeglich beginnen lassen." He does not, however, state any reasons for the "unmoeglich." "Laws, $785 \mathrm{~B}$.

:Polit. VII., 16, 3.

INote to Ion, line 700 . 